\title{
A CRITICAL HISTORY OF COLONIZATION AND AMERINDIAN RESISTANCE IN TRANS-APPALACHIA 1750-1830: THE PROCLAMATION WARS
}

\author{
BY \\ (C)2010 \\ Richard Keith Arnold
}

Submitted to the graduate degree program Global Indigenous Nations Studies and the Graduate Faculty of the University of Kansas in partial fulfillment of the requirements for the degree of Master's of Arts.

Chairperson Dr. John Hoopes

Dr. Andrew Whitford

Dr. Ray Pierotti

Date Defended: February 26, 2010 
The Thesis Committee for Richard Arnold certifies that this is the approved Version of the following thesis:

\section{A CRITICAL HISTORY OF COLONIZATION AND AMERINDIAN RESISTANCE IN TRANS-APPALACHIA 1750-1830: THE PROCLAMATION WARS}

\section{Committee:}

Chairperson Dr. John Hoopes

Date Approved:여/15/2010 


\begin{abstract}
A careful examination of events in Colonial Trans-Appalachia-the region geographically encompassed by territories west of the Appalachian Mountain Range and east of the Mississippi River-at the time of the French and Indian

War facilitates analysis of regime formation amongst Amerindian and European Colonists. This thesis examines the effects of contact on Amerindian and European polities in a form that seeks relevance to contemporary issues. It draws on historical timelines that immediately pre and post-date the French and Indian War. It argues how distinctive decision making structures used by Amerindian and European societies provide preliminary models for understanding how their respective forms of sociopolitical organization conditioned political relationships.
\end{abstract}




\section{Acknowledgements}

Where to begin. I am deeply indebted to my wife Carlene who sacrificed much, maybe most, of our usual personal time during the early years of our marriage so that I could finish this work. There are not enough words. This also applies to Jerry Painter, Robert Francis, Susan Bates, and Steve Bartha. I am further grateful for the input and support I received from various professors who were either indirectly or directly involved in this thesis. For those indirectly involved, I would like to thank political science professor Dr. Schumaker for teaching a great political theory class and Professor Gaar for years of friendship as I made my way through the halls of the academy. She was my first political science professor. I would also like to think Dr. Middlemass who chaired my undergraduate thesis and helped prepare me for graduate school.

As for my committee members I am grateful to my original Chair, Dr. Yellow Bird, who always provided a continual critique of the work I was developing so that I could consider alternative explanations and drove me to build a substantial evidentiary record. Dr. Yellow Bird left for a new position. My second Chair, Dr. Hoopes picked up where Dr. Yellow Bird left and pressed me to develop the theory from the evidentiary record by sharing a little of his own work which really opened up my creative and analytical thinking. Thank you. Both Dr. Yellow Bird and Dr. Hoopes are amazing individuals in that they both have fearless minds and are dedicated to an open discourse in academia. Both agreed to Chair my thesis while both were hard pressed for time. Again, thank you. I further would like to offer my gratitude to Dr. Whitford. He was a committee member on both my undergraduate and graduate thesis committees. He is also the first person I published a paper with. Working with Dr. Whitford has been a great pleasure because of his straightforward and candid approach to his working relationships. I have found him to hold high standards for students while also providing the kind of support that expands his students' horizons. I would also like to thank Dr. Pierotti for joining the committee at a late stage. He provided input that sort of anchored my thinking and allowed me to step back and re-evaluate some of my conceptual development. I would also like to thank the Global Indigenous Nations Departmental staff, especially Betty. The staffs at the Watson and Anschutz campus libraries were also very helpful.

Lastly I would like to thank my classmates who I entered the program with. 
Table of Contents

\section{Section I}

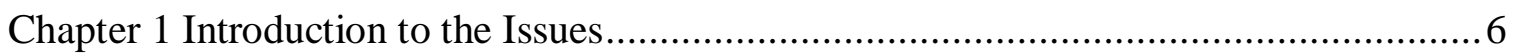

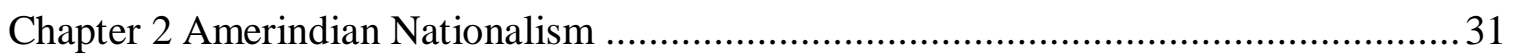

Chapter 3 An Analysis of Conflicts, Proclamations, and Consequences.........................54

\section{Section II}

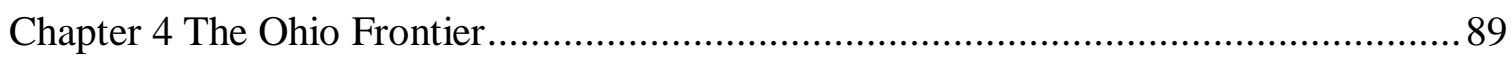

Chapter 5 Six Nations a Frontier Broker............................................................... 100

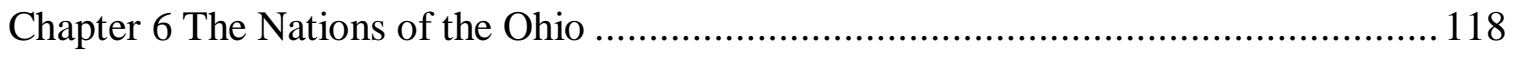

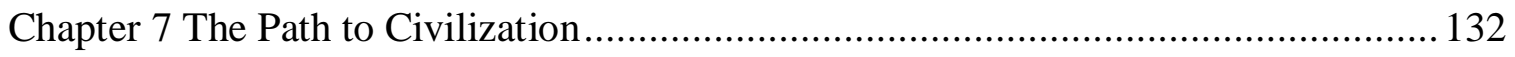

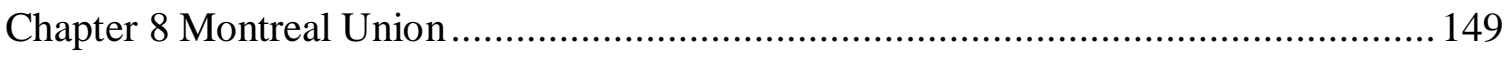

Section III

Chapter 9 Models of Democracy, Colonialism, and State Formation ............................ 165

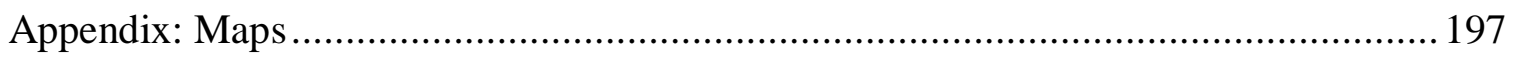

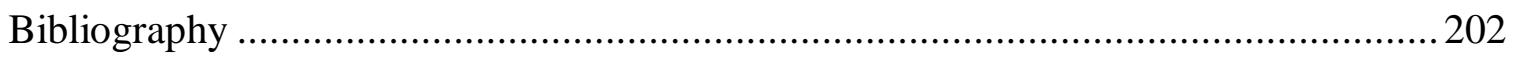




\section{Section I}

\section{Chapter 1 - Introduction to the Issues}

This study will look at the role of trade and land tenure in the conflicts that arose in Colonial Trans-Appalachia, defined temporally as the period between 1754 and 1812 in the geographic region west of Appalachian Mountain Range and east of the Mississippi River. Trade

and land tenure were central to regime formation during this time in this region. From the axes of the various regimes the origins to competing national and state ventures can be articulated. Colonial Trans-Appalachia represents a critical era in North American history. The outcomes of the region's struggles determined to a decisive degree the future course of North America. TransAppalachian wars settled many disputes among Europeans who had been jockeying for North American possessions and eventually the relationship among Colonial Europeans and their parent countries. Yet, some are unresolved as present day Quebec gives an apposite voice to an ethnic Colonial French nationalism. The Amerindian, or American struggle to retain an independent status has continued to this day. ${ }^{\mathrm{A}}$

The French and Indian War (1754-1763), maybe better stated as the French and Indian War, essentially failed to resolve the imperial contest between England and France in North America. The French and Indian War named from the perspective of the Anglo Saxon was much more complex in its geo-political dynamics than simply a struggle pitting the British against the

\footnotetext{
A Scholar Forbes (1993) discusses the repopulation of the Americas by identifying the indigenous populations of the North, Central, and South America as Americans while identifying migrant colonial populations in the Americas with the prefix of their continents of origin. For example, Euro-Americans or African-Americans. I originally decided on the term Amerindian to imply First Americans while admittedly not being entirely comfortable with the term.
} 
French and their Amerindian allies. The war was also a contest that followed the earlier and much more indecisive failures of the King William’s War, Queen Anne’s War, and King George's War in the 1740s. ${ }^{1}$ These wars conducted in the interest of expanding national trade empires in which local indigenous became exceedingly entangled. The war was initiated in the midst of English and French negotiations over a suitable boundary line between their two Colonial empires in North America. The negotiations continued during the war and included proposals that would limit both French and English claims to the continent. By default and intent this arrangement acknowledged an unoccupied zone in Trans-Appalachia wherein the residing Amerindian nations stood as a bulwark to further territorial expansion. ${ }^{2}$ At the time the British Colonies and the French would have been hard pressed to expand their empires into these interior regions. This is evident when considering the events of the French and Indian War. Furthermore, these negotiations were typical European solutions that precluded direct participation of Amerindian leadership.

The conclusion of the French and Indian War initially seemed to provide an outcome in favor of British imperial interests. The North American experience had already been a partial or weighted successful British colonial venture with numerous coastline settler communities. However, the English were far from being free of French interference. Moreover, the British Imperial state would face continued dissension among its own colonies. Before the official peace that ended the war France transferred its claim to the Louisiana territory to Spain in hopes of preempting British hegemony on the continent. The British would at the conclusion of the American Revolution attempt to check the expansion of its former colonies by transferring territorial claims to southern Trans-Appalachia to the Spanish. The Spanish never effectively 
fulfilled this role as a counter threat in the region's balance of power dynamics even though they too parlayed with Amerindian nations to prevent the emergence of one dominant European actor in the region. In all these plans Amerindian partnerships were considered necessary for success yet between the events of the American Revolution and the invasion of the Ohio Country by the Federal government of the United States in the 1790 Amerindian resistance would only acquire the necessary logistics for five offensive operations against the early American Republic. ${ }^{3}$ This is largely a failure on the part of the Europeans who either over committed themselves or failed to deliver on their obligations.

England expanded its empire globally during the French and Indian War by also gaining territories in Africa and India. The Treaty of Paris officially ended the French and Indian War for European participants. ${ }^{\mathrm{B}}$ The status of Amerindian nations was tenuous in the broad region of Trans-Appalachia despite agreements concluded by Amerindian nations and British colonial authorities. The primary resistance to colonial expansion into the interior resided with Amerindian society who had to contend with the ever changing and unstable nature of European colonial administrations.

The French and Indian War was a regional strategic theater in which local trade and land tenure conflicts prompted a much larger global scale war commonly referred to as the Seven Years War. ${ }^{4}$ The Seven Years War was a global conflict that was ordered around the ambitions of European kingdoms or early European nation-states and marked a beginning to a number of global, colonial, and imperial wars that continued into the $20^{\text {th }}$ Century. War participants

\footnotetext{
${ }^{B}$ The Treaty of Paris that ended the French and Indian War was concluded in 1763.
} 
included all the major European powers of the day. ${ }^{\mathrm{C} \& 5}$ Within such a context the "world wars" of the Colonial and Postcolonial era were largely determined by unresolved issues amongst great European powers. The Treaty of Paris determined the then current world order wherein the Great Colonial Powers divvied up their claims to worldly dominions. For example, the claim to the Philippine Islands in the Western Pacific Ocean was returned to Spain. The geographic scale of the treaty included Africa, the Americas, Europe, and southern Asia.

An immediate question for imperial England in North America no longer beleaguered by New France was the manner in which it was going to administer its colonies or manage its relationship with the Amerindian nations of the interior of North America, west of the Appalachia Mountain Range, and east of the Mississippi River. There was much too consider, the fur trade being but one of many under contention. Under the terms of the Paris Treaty, as noted before France was able to transfer ownership of the Louisiana Territory to Spain in recognition of Spain’s loss of Florida and in light of her comradeship during the war with England. ${ }^{6}$ This transfer of ownership included the port of New Orleans. While the British gained total control of the trade center of the Great Lakes and St. Lawrence River region they would continue to lose approximated revenue of £80,000 of British Sterling from the fur trade occurring west of the Wabash River in which the furs were transported down the Mississippi River to the port of New Orleans which was outside of England's jurisdiction. England had plans to subvert

\footnotetext{
${ }^{\mathrm{C}}$ Amerindian participants included: Iroquois League, Delaware, Shawnee, Ottawa, Ojibwa, Wyandot, Creek, Cherokee, Choctaw, Chickasaw, Mingo, Miami, and Pottawatomie Nations. European participants included: Great Britain, France, Spain, Holy Roman Empire, Portugal, Russia, Sweden, and Saxony among others.
} 
the New Orleans trade but with no eventual success. ${ }^{7}$ Already, economic regulation alone presented a high stakes game to participants.

In all this economic globetrotting England—like other European agents commonly operated in and occupied foreign territories without first establishing sound diplomatic ties to local inhabitant nations and acted upon an assumed authority; commonly a conquering and exploitive authority. Beyond the fur trade, other issues for England included land policy, public revenue to finance new and existing colonial enterprises, and the necessity to formalize relations with Amerindian nations, while also finding a manner to fund its war debts and existing military deployments. In periods of crises when Colonial authorities required Amerindian assistance, the appearance of legitimate diplomatic ties were upheld, but these usually crumbled with the passing of the crises coupled with colonial economic goals.

Normatively, Amerindian polity of Trans-Appalachia during 1754-1830 should be characterized in cross cultural terms of state seeking societies. Primitive, savage, and pre-modern interpretations of Amerindian political organization are inappropriate if the organizational characteristics of Amerindian society served its populations in a meaningful and effective manner from the individual to the aggregate. ${ }^{\mathrm{D}}$ Furthermore Amerindian social organization

\footnotetext{
${ }^{\mathrm{D}}$ The modern label as a descriptor of an historic age (1500s to the 2nd World War of the 20th Century) is somewhat problematic in universal or cross cultural terms. Indigenous Scholar Smith (1999) suggest the modern era for indigenous populations is an era noted for two priori themes-resistance and survival. I suggest there may be a neutral ground for which to consider the modern era. The modern era understood through generic factors such as the rapid rise of global trade, frequent inter-societal contact, and global population redistribution may provide such an opportunity. In other words, the modern era is an era of globalism and colonialism- these two interpretations to history have a dialectical relationship. It is unlikely that the populations of the world would have remained isolated from one another. On the other hand, the philosophical split between the philosophers or men of reason with the traditions of the church was an event that occurred in the context of European society-it was an unresolved local and social event in which both European traditions were artificially transplanted upon indigenous populations. One cannot without careful consideration reduce the modern era as definitively European. For example, scholar Jennings
} 
suggests a complexity that was absent or functionally moderated in Colonial social orders. ${ }^{\mathrm{E}}$ This complexity in part explains the difficulties of the Colonial or contact era of Trans-Appalachia. It alone cannot explain the difficulties experienced. The inherent goals of colonial ventures are problematic. Their success too often was only achieved through the means of exploitation derived from imperial policies or local phenomena that beset more equitable social designs.

Besides at the time, European colonies in North America were themselves not state societies but rather dependent society types contingent upon greater political organizations in their overseas mother countries. These dependent colonial societies derived their status from what may potentially be characterized as pre state European monarchial societies. In a balanced analysis the early colonies were not only dependent upon their European countries of origin but also to a large extent, upon the cooperation of Amerindian societies. In this regard European colonies were also state seeking societies. ${ }^{\mathrm{F}}$ The British colonies are unique in that their charters gave them some level of local control through the selection of some officials but also operated with officials appointed by the royal court. I will advance an analysis that attempts to identify the various underpinnings to state seeking behavior through an historical presentation of Colonial

(1975) questions the likelihood of European success in the Americas without the knowledge and technology of Amerindian society. In addition, Jennings frames the issue by asking in what manner is the modern state is obligated to indigenous society.

E Jennings (1975, Page 72 and 85) reports the position that Amerindian integration into the "executive power" or hierarchical command structure of Euro-American stately society had the effect to create a peasantry with severely limited social agency. He adds that Amerindian contact with Europeans had the effect to reduce economic differentiation and specialization as the only substantial trade products or materials of pre-contact intertribal trade that survived were those sought after by European merchants.

F Jennings (1975, Pages 107, 109 \&) reports that colonial charters were in line with English law, customs, and governance were "feudal" in substance and character. In the 1600s the legal precedent had been set in which "colonial governments" were equated with a "lordship" therefore ensuring Crown jurisdiction over colonial matters rather than Parliamentary jurisdiction. The legal status of the British colonies has also been described as "estates." 
Trans-Appalachia. ${ }^{\mathrm{G}}$ My methods identify the strategies employed by Amerindian and European agents.

\section{Additional Thesis Goals}

This thesis sets the stage for contemporary state politics in the United States. The final struggles in colonial Trans-Appalachia occurred primarily between Amerindian polities and the early Republic. These events in all can be measured as an apocalyptic event for Amerindian society. ${ }^{8-\mathrm{H}}$ My first goal is provide an interpretive historical sketch that illuminates the political arena of Amerindian Affairs experienced today through a set of historical briefs. My second goal is to illuminate the manner in which the pursuit of national and counter nationalist strategies resulted in the disenfranchisement of many Amerindian polities that are not recognized through Federal enrollment and exist today as "non-status" tribal nations, without any formal status or only a limited independent political status.

Donald Fixico reiterates Federal policy effectively developed “as a problem to be solved.”9 Tribal nationalism has not been acknowledged in that tribal sovereignty has been reduced to something less than a national experience. Sadly, the problem has been effectively resolved in favor of colonizing agents such as the federal government. While Federally recognized today work toward sovereign self-determination in line with U.S. policy, they appear to be emerging as a new sort of political community to be ordered in the ranks of U.S. federalism next to municipalities and states. Concurrently, many non status tribes continue to seek entry into

\footnotetext{
${ }^{G}$ For the purpose of this study, Colonial Trans-Appalachia is also referenced as the interior or the western country. ${ }^{\mathrm{H}}$ Scholar Gross (2002) suggests that colonialism in North America had such a relatively immediate, profound, and lasting effect that it resulted in the large scale disintegration of Amerindian society ranging from such general institutions associated with governance to the severe breakdown of the family unit.
} 
the new federal order as witnessed by the letters of intent filed by different groups with the Bureau of Indian Affairs (BIA) of the U.S. Department of Interior. While Federally recognized tribes hack out their existence in the courts and lobbies of Congress, non-status tribes continue to contend with accusations denying their status as a tribe, a people, and so forth. From this situation the concept of Amerindian nationalism has remained a contested, fluid, and undefined. There has never been one prevailing notion.

We can revisit the origins of this so called problem to indeed discern the nature of Amerindian nationalism in the context of a Trans-Appalachia history. From this framework the means to distinguish the motives at work will be achieved by exploring the range of tribal political strategies that developed with the introduction of European authority in TransAppalachia and concomitantly, how the outcomes of these strategies bear on tribal populations today. The situation of these non-status groups may be reconciled through a critical examination of Trans-Appalachia history in the terms of a Postcolonial critique. The key issues addressed and reported on from the backdrop of Postcolonial Theory include unknown or hidden histories of indigenous groups, identity politics, state endorsed violence, and nationalisms born of the colonial experience. ${ }^{10}$

Since at least the 1930s to the current day, the United States has seen a number of Amerindian nations attempt to establish formal political ties with either the federal government or local state governments. During the 1930s the Indian Reorganization Act effectively began returning local control to tribal nations. In other words the IRA established the legislative trend towards self-governance for Amerindian nations. Self-governing Amerindian nations today hold a legal status descriptively known as Federal recognition. Federal recognition is a formal legal 
relationship between a tribal government and the U.S. government primarily administered through the BIA. Historically, the Bureau of Indian Affairs originated in the U.S. Department of War. Currently federal recognition conveys a sovereign to sovereign government relationship in theory, in practice it may be described more accurately as a relationship between a greater sovereign and a lesser sovereign.

Incidentally, a number of Amerindian nations have chosen to forsake a relationship altogether with any government entity. For example, one such tribe is the Independent Traditional Seminole Tribe of Florida associated with Danny Billie. ${ }^{11}$ The number of non status tribes is unknown but there are acknowledged to be dozens of these groups that vary greatly in their demographics and organization. Why these tribes choose not to seek government recognition is open to speculation. I would consider it arrogant to speak on their behalf without first having established a dialogue with them. However, I hope my exposition of the history of western expansion will assist in understanding these sorts of decisions.

Debates concerning non-status tribes, are grounded in the unnerving practices of identity politics and the politics of recognition. ${ }^{\mathrm{I}}$ These inevitably hinge on the question of legitimacy of tribal groups that exist outside the federated order in contrast to the groups of tribal nations officially recognized by the U.S. federal government. The issue of these "non-status" tribes is far reaching and often provokes sharp dialogue focused on "ethnic fraud" by members of groups who have recognition. ${ }^{12}$ A critical history of North America may disclose a record of the

\footnotetext{
${ }^{\text {I }}$ For a quick overview of the subject of identity politics see the Stanford Encyclopedia of Philosophy @ http://plato.stanford.edu/entries/identity-politics/ \& For a good discussion on the subject of recognition politics see the article written by Glen Coulthard in the online magazine-New Socialist @ http://newsocialist.org/newsite/index.php?id=1011
} 
existence of numerous non-status tribes, bands, families and so on. This can be achieved by close examination of the practices and effects of early policies toward Amerindian societies, and the conflicts that arose within Amerindian societies in the context of aggressive colonial intervention.

Recognition schemes that are a product of colonialism ensures variation in tribal status politically, socially, and culturally. Some groups hold a non-Federally recognized status due to a long history of the United States employing a policy of non-recognition ${ }^{J}$ to achieve its goals associated with territorial expansion. Explicative More particular to this study is the early Republic's agenda to establish an "Indian-free zone” in the region known as Trans-Appalachia. ${ }^{13}$ Other non-recognized groups, for example, such as the Delaware, Shawnee, Wyandot, and Miami families of northeastern Kansas are remnants left over from the calamity of the former U.S. removal solution; a solution that was more palatable to government humanists than actual extermination. Extermination as a solution was actually considered by at least three U.S. Presidents including George Washington, Thomas Jefferson, and William Henry Harrison. ${ }^{14}$ Some relevant dialogue by George Washington reads, "It is much to be doubted whether these wretches will ever suffer our Frontiers to enjoy tranquility till they are either exterminated, or removed to a much greater distance." 15

Given this last, it is surprising that some wonder why some tribal groups chose to go it alone and forsake any sort of relationship with the federal government. There are many reasons,

\footnotetext{
${ }^{\mathrm{J}}$ In classic usage and in international law, non-recognition refers to the act of one government's diplomatic choice not to recognize the legitimacy of another government. In the context of post-colonialism non recognition as a state's diplomatic choice can compound the issue even further by not even acknowledging a legitimate claim to an ethnic, cultural, or national identity.
} 
most due to active strategies towards their extinction. Some individual tribes were forcibly placed under the authority of larger tribes such as was the case with the Loyal Shawnee and the Cherokee Nation of Oklahoma. Only later would the Loyal Shawnee gain an independent Federally recognized status. ${ }^{16}$ In consideration of the frenzied creation of the United States driven by its early nationalist goal of expanding its territorial dominion to the Pacific Ocean, there is much to uncover in examining its creation. Some tribes seek only limited recognition or have failed to achieve their recognition goals. These sorts of groups included the Miami Nation of Indiana or the Shawnee Nation United Remnant Band of Ohio who sought and obtained relationships with their local state governments. ${ }^{17}$

It would be beyond the scope of this thesis to review every application for federal recognition submitted in the past 30 years and it would be unrealistic to think that a series of smoking gun documents would be found in every case. Non-status tribes are unlikely to have been documented on government rolls as they were not historically beneficiaries of public annuity programs or land tenure schemes in many cases. Rather the evidence for their existence rests in other actions taken by government agents and recorded historical events. For example the 1817 Fort Meigs treaty rewarded those Shawnee bands who had aided the United States during the war of 1812 with annuities and land entitlements while barring those Shawnee associated with Tecumseh's band from the treaty process. ${ }^{18}$ The Shawnee associated with Tecumseh had not only defended their homes and Canada by virtue of their reluctant partnership with the British, but had invaded the territorial claim laid by the United States in the Congressional passage of the Northwest Ordinance in 1787. At the Treaty of Ft. Meigs and in the commissioners own language: 
That in consideration of the faithful services of the Shawnees in the late war with England, and for divers of other considerations, the government of the United States settle on the Shawnees an annuity of two thousand dollars annually, forever, to be paid to them at Wapaughkonetta. ${ }^{19}$

Ohio became a refugee region of non-recognized Indians who were rejected from the reservation system of the annuity chiefs and the U.S. social order during the years following the War of 1812. The annuity chiefs who controlled the reservations denied rights of citizenship to non-status Indians. ${ }^{20}$ But Amerindian refugees or dislocated populations may date to an even earlier decade when a traveling missionary in far western Pennsylvania in 1753 noted from his visit in the Amerindian town of Shamokin, "it is uncomfortable for Indians there, for if they plant they cannot enjoy it, so many strange Indians pass through the town whom they must feed.”21

Today, no less than sixty-two tribes are currently recognized by sixteen states in which at least five of those states host tribes originating in Trans-Appalachia where additional states have developed some type of "recognition scheme.”22 In a key respect, many of these tribal polities, families, etc, can probably be viewed as tribes that were in former times endured something similar to termination whether it was the result of an official act of the Federal government or not. In some cases Amerindian polities lost formal political status to negotiate several decades prior to the official policy of termination. Termination was an official policy during the 1950s and 1960s in which the federal government sought to integrate tribal citizens into society at large by ending their status as a Federally recognized tribes and extending to them a single exclusive citizenship in the United States. Similar sorts of schemes were applied during Oklahoma’s statehood in which the government of the Cherokee Nation in Oklahoma was dissolved by 1906. The Cherokee Nation of Oklahoma loss of tribal status is associated with the General Allotment 
Act of 1887. ${ }^{\mathrm{K}}$ It would take until the 1970s before they would regain their federal recognition. The early practice by the U.S. of nonrecognition as a diplomatic tool, also practiced earlier by England and France, gave rise to a long history of tribal termination whether it occurred in the field of conquest or in the halls of the executive, congressional, and judicial branches of government. For example the U.S. government would routinely only negotiate with certain tribal polities based on how those polities happen to fit into U.S. policy schemes or affect U.S. tribal allies. Similarly England and France were reluctant to recognize the authority of tribes who existed outside established trade networks.

Between the 1740s and 1850s the struggle for the North American interior is highlighted by a number of apparently distinctive conflicts that hold some common underlying threads. Wars of this era include the French and Indian War, the American Revolution, and the War of 1812. Other wars of this era include Pontiac’s War, Cornstalk’s War more commonly known as Lord Dunmore’s War, the Wars for the Ohio River Valley beginning in the 1780s, the Chickamauga Resistance, the Red Stick Resistance, Black Hawk’s War, and the Seminole conflicts of the Old Southwest among other conflicts associated with time frame. The status of Colonial society relative to that of Amerindian society was consistently at issue even when a specific war involved Colonial societies in conflict primarily with each other.

What arose from mandates were an eventual colonial rebellion and a series of wars that marginalized Amerindian society as their homelands were usurped in the march westward. After

\footnotetext{
${ }^{\mathrm{K}}$ The General Allotment Act or Dawes Act ended tribal legal status by breaking up tribally held lands and distributing land allotments to individual Amerindians. The act further opened up tribal lands to non-Amerindians for settlement or commercial development. The Dawes Act was followed by the Burke Act of 1906 which prompted further tribal land loss and fostered Amerindian assimilation through exclusive U.S. citizenship.
} 
the French and Indian War the British attempted into issue in a new era of colonial administration with King George’s Royal Proclamation of 1763. A significant tenant of that new administration included an arrangement of borders that demarcated colonial populations from Amerindian populations. In this aspect the attempt at a new colonial administration was designed to maintain colonial dependencies to serve British commercial interests while easing Amerindian concerns over unwarranted land annexation practices. Taken as a whole, these post—French and Indian War conflicts can be grouped together as the Proclamation Wars.

At the end of these wars it was clear as to who would control the future of North America. With the 1830 Indian Removal Act the Mississippi River, the far western boundary of Trans-Appalachia, was gained and the quest to reach the Pacific Ocean was to come with insidious diligence. This is seen in the advance military expedition by Lewis and Clark a mission of intelligence gathering before the invasion of the Trans-Mississippi Region. It is unreasonable to think that Amerindian polities would remain stable and functionally intact under such a scenario. The whole scenario of the Proclamation Wars and Indian Removal Act resulted in a diaspora of tribal populations and remnant tribal polities. To think otherwise would be naïve. While some of these non-Federally recognized groups have maintained more coherent communities over time, such as the Miami Nation of Indiana, others have had to struggle at restoring their communities such as the widely dispersed Chickamauga Cherokee also known as just Chickamauga a tribal nation that entered into an armed resistance movement over activities of the Henderson Land Company. In the region of the Old Southwest the Chickamauga more often than not stood alone in a two decade long resistance after the American Revolution. ${ }^{23}$ The Chickamauga were a key member in an Amerindian regime that stretched to the northern regions 
of Trans-Appalachia and more specifically to the resistance movements occurring in the Ohio region. They developed close associations with the Shawnee and Delaware among other nations as the Chickamauga also participated in the defense of the Ohio Country during the 1790s.

The Amerindian regime that formed to contain western expansion into Trans-Appalachia has can trace its roots with such early leaders as The Mortar of the Creek Nation, individuals from the Shawnee, Delaware, Wyandot, and Miami Nations of the Ohio region, and Pontiaceven though Pontiac also sought the restoration of French power. Later leaders of note included Dragging Canoe, Captain Pipe, and Cornstalk. ${ }^{\mathrm{L}}$ In the 1790s Amerindian regime leaders also included Blue Jacket, Little Turtle, Buckongahelas and the Badger. By the War of 1812 leadership had passed to such individuals as Tecumseh, Roundhead, the Trout, Tenskwatawa, and Main Poc.

Outlining the dispersion of ethnic Cherokee is no easy matter. In 1788 Cherokee migrations west of the Mississippi River into Missouri and Arkansas were becoming more common. So many Cherokee including Chickamauga inhabited villages in the area that Spanish officials were not able discern their numbers. ${ }^{24}$ Dislocated Cherokee populations or refugees reported in central New York and Pensacola, Florida during the opening years of the American Revolution. ${ }^{25}$ During the days of forced removal in 1838, the Ocanluftee Cherokee or Eastern Cherokee of North Carolina were not hiding in the mountains but were instead actively cooperating with the U.S. Army in arresting unruly Cherokee citizens residing in the removal towns. This cooperation led the Ocanluftee gunmen to participate in an impromptu firing squad.

\footnotetext{
${ }^{\mathrm{L}} 1770$ s to 1780 s.
} 
The unruly Cherokee from towns designated for removal were killed for their role in the deaths of some U.S. soldiers. ${ }^{26}$ Earlier, many Chickamauga and other Cherokee voluntarily removed themselves to Arkansas for lands reserved to them by treaty in 1817. Two decades later with the forced removal Cherokee populations still residing primarily in Georgia the Federal government attempted to force the Arkansas government to integrate themselves into the jurisdiction of the new Oklahoma Cherokee government under John Ross. ${ }^{27}$ The migrations associated with the treaty of 1817 were by no means the first migrations to Arkansas as up to a thousand Chickamauga had migrated to Arkansas in $1809 .{ }^{28}$ Cherokee migrations are much more complex than implied by the typical history associated with the story of the Trail of Tears. The typical history of the Trail of Tears itself has come under some recent criticisms. $^{29}$

I urge the reader to consider the nature of the North American colonial project that eventually emerged after the Royal Proclamation as a project in imperial nationalism that created the United States. It is known today through an arbitrary and ubiquitous claim to much of North America along with the Amerindian nationalisms that either sought sanctuary through armed opposition to this claim or who sought relief from the accompanying onslaught of this claim through appeasement - however reluctant it may or may have not been and just potentially necessary.

One significant issue for many of these tribal groups is whether or not the pursuit of federal recognition is really in their best interest. They wonder if the end result of the process will serve to restore their communities even though this choice has been considered and resolved by many Native polities. Federal recognition as a choice should be considered with a risk and reward analysis, but it should be noted that these were unavailable to 18th century Amerindian 
nations. Among contemporary risks, one only needs to observe the invasive role of the B.I.A. amongst other federal and state authorities or the manner in which casino politics has erroneously affected tribal citizenship standards or community stability in some limited cases. ${ }^{30}$

One approach to understanding the status granted by federal recognition can be viewed through the framework of protectionist economic regulation. ${ }^{31}$ The federal government legitimizes tribal authority through licensing tribal governments in which the licensed governments can then pursue the securitization of public entitlements and exploit private economic privileges, e.g. the right to conduct gaming activities. Such licensed governments can then participate in the political process (lobbying) to prevent admission into the system by potential competitors-non-Federally recognized tribes. Non-Federally recognized tribes are at a distinct disadvantage. They lack the financial parity to compete with Federally recognized tribes in political gaming. While the political process provides a right for all to participate it does not mean that all participate with the same measure of resources. Therefore justice may be untenable - not that federal recognition is necessarily the means to achieve social justice. Critiquing federal recognition through the lens of economic regulation alone is a reductionist approach for it precludes other issues that go along with political autonomy.

Federal recognition eventually became the United States policy choice of preference alongside a policy of non recognition as it fit the needs of the Federal Government and its constituents. Through this choice of internally domesticating tribal authority, the United States has committed itself to an entanglement of affairs that it hopes to endure-as does the tribal party involved in the affair. The problem to understand the damage that was done through colonialism, the damage that continues to be done and the confusion that it promotes. Part of that 
damage can be remedied in an impartial review of history that explains how present conditions came to be to alleviate the confusion accomplished with the direct and collateral damage of colonialism. Part of the problem is the manner in which Amerindian society has been historically interpreted through texts that are either eroticizing or dispassionate.

\section{Methodology}

The study operates within the narrative, topical historical research tradition. Although it was my original intention to do so I do not utilize interviews or operate from oral tradition for several reasons. First and foremost I lacked the funds and the time to conduct a thorough interview process. I initially began this process by spending the summer of 2005 in Ohio traveling on my own finances. However I had also lined up interviews with individuals whose habitats stretched from Arkansas, Missouri, Tennessee, Alabama, Florida, and New Jersey. Unfortunately in these circumstances, telephone, email, or any other long distance interviews were not feasible. I have also found that people are very uncomfortable discussing such personal matters with individuals they have not met in person regardless of who may have referred or vouched for them. While I am an insider into some of these communities, my reach and intimacy only stretched so far.

\section{Temporal and Geographic Scope}

The Appalachian Mountain Range is the dominant landform of the Eastern United States and served initially as a natural barrier to westward expansion. It is politically significant in that the Royal Proclamation of 1763 attempted to establish an international demarcation line between the British Colonies and the Amerindian Interior. The demarcation line was fairly consistent with the physical mountain range itself. For the purpose of this study, the Trans-Appalachian region is 
further divided by four sub regions: 1) the Old Northwest Territory that encompasses the current states of Ohio, Indiana, Illinois, Michigan, Wisconsin and Minnesota, and 2) the Old Southwest Territory represented by the present states of Kentucky, Tennessee, Alabama, Mississippi, 3) and Florida, and 4) the territory of upstate New York and southeast Canada. Granted, Florida would seem to be an unconventional selection but in the Colonial era Florida was divided into western and eastern divisions. The western portion extended across the Gulf of Mexico coast line as far as the port of New Orleans. the Iroquois League, or the Six Nations, is represented in the study for their unique role from the Trans-Appalachia locale of upstate New York and southeast Canada for they had a substantial impact in the affairs of the Old Northwest and Old Southwest geographies.

Trans-Appalachia is defined as the region between the Appalachian Mountain range and the Mississippi River. The range extends itself from southeast Canada to central Alabama and historically was the geographic frontier to the British colonies. Settler movement westward and colonial military campaigns into the region would rely on different roads that cut through the Appalachian Mountains such as the Mohawk Trail of western New York and the Forbes Road that stretched from Philadelphia to Pittsburgh. The latter granted access to the Ohio River which in turn granted access to the Mississippi River. Another example was also Braddock's Road that connected Baltimore to Pittsburgh. Further south, the Cumberland Road adjoined the Potomac and Ohio Rivers. At the far southern end of the Appalachian Mountain Range the Great Valley Road provided access to the Cumberland Gap from which the north-south Wilderness Road provided access to the Ohio and Tennessee Rivers. In addition there was a compliment of roads used by Amerindian nations to conduct movements and trade within the interior. 


\section{Source Materials}

In the process of conducting my research I discovered there is plenty of material available in primary and secondary sources to conduct the study. The study is weighted toward secondary resources but relies on a triangulated analysis of the sources to attain consistency, accuracy, and reliability in reporting. Primary sources such as private journals, diaries, recorded minutes, and recorded personal histories were used when they could be readily accessed. Secondary sources include dissertations, journals, anthologies, and books. Source material publication dates range from 1855 to the present with scholarly accounts from at least the United States, Canada, England, and Japan numbering roughly 150 works cited. This provides a broad array of representation covering the topic from which to verify and analyze emergent and outstanding positions for theoretical propositions and conclusions.

\section{Theoretical Aims}

Dowd suggests the error in understanding the dynamic between various native polities is the manipulation of the tribe or nation as the unit of analysis in that both the intratribal and intertribal element must be acknowledged. ${ }^{32}$ Other scholars have relied on other units of analysis to understand tribal politics. White considers the matter at the level of the village or town noting that village composition was commonly multi-tribal in its citizenship. ${ }^{33}$ Further delineation points towards the clan as a worthwhile unit of analysis. ${ }^{34}$ I will use the generic concept of polity as a unit of analysis because it essentially identifies what is at issue. Simply put, a polity is significant in that its members regardless of tribal, village, or clan citizenship shared the same values and goals; but that is not to say that the units tribe, village, or clan did not have a 
significant role in political affairs. I suspect kin networks also held a role but that this role should not be overstated. ${ }^{\mathrm{M}}$ For the purpose of this thesis polity will signify strategy and vice versa.

Four predominant polities emerge from the research. First a containment polity that sought to maintain a national existence and prevent colonial expansion into the interior of North America through dedicated hard power discourses and intertribal affiliations who participated reluctantly in security regimes with European kingdoms. Secondly, an appeasement polity that favored soft power dialogues with Colonial authorities and later the American Republic primarily through land concessions, trade agreements, and annuity subsidies with the expectation of maintaining a diminished national experience as agreements entered often afforded colonial authorities undue influence into the domestic affairs of Amerindian polities. Third, a free rider polity that actively used both hard and soft power engagements to gain status, trade benefits, and territorial benefits by manipulating the balance of power between the containment/appeasement polities and the colonial establishment much in the same manner as a colonial power would have done. This polity at times appears more as a possible cooperative polity that sought full partnerships resulting in regime making with Colonial authorities. The final polity that attempted by choice or circumstance to maintain a non-alignment posture and resist entry into any standing or burgeoning regime. These strategies were not necessarily static in application. As regional

\footnotetext{
${ }^{\mathrm{M}}$ From the discipline of anthropology Amerindian society has been described as "kinship states" noted for a sociopolitical structure organized through extended familial relationships such as clans that were incompatible with European bureaucratic state forms. (Jennings, 1975) Yet, in the contemporary politics of America we can observe how some families are forces to be reckoned with such as the Kennedys or the Clintons, for example. So in retrospect, some Amerindian leadership organizations may parallel this sort of phenomena rather than be indicative of hereditary title or privilege. Besides the turnover rate of Amerindian leadership due to disease, warfare, and slavery substantially reduces the likelihood of a hereditary system and places sever limitations on an overly familial system of leadership. Let alone a historical record that indicates otherwise.
} 
political dynamics changed so did the strategies employed by some Amerindian polities. Other Amerindian polities remained more or less consistent with certain strategic themes. 
${ }^{1}$ Graves, William Hilton. (1982). "The Evolution of American Indian Policy." Dissertation at Florida State University. Ann Arbor, Michigan: UMI.

${ }^{2}$ Savelle, Max. (1940). The Diplomatic History of the Canadian Boundary 1749-1763. New Haven: Yale University Press.

${ }^{3}$ Connelly, Thomas Lawrence. (1964). "Indian Warfare on the Tennessee Frontier, 1776-1794: Strategy and Tactics." The East Tennessee Historical Society’s Publications. No 36: 3-22.

${ }^{4}$ Ropes, Arthur R. "The Causes of the Seven Years' War.” Transactions of the Royal Historical Society. 1889. Vol 4 New Series pp 143-170. Royal Historical Society.

${ }^{5}$ Nester, William R. (2000). The First Global War Britain, France, and the Fate of North America, 1756-1775. Westport, Connecticut \& London: Praeger.

${ }^{6}$ Emmanuelli, Loliannette. (1990). "Spanish Diplomatic Policy and Contribution to the United States Independence 1775-1783.” Dissertation at the University of Massachusetts. Ann Arbor, Michigan: UMI.

${ }^{7}$ Hatheway, G.G. (1957). "The Neutral Indian Barrier State a Project in British North American Policy 1754-1815." Dissertation at the University of Minnesota. Ann Arbor, Michigan: UMI.

${ }^{8}$ Gross, L. "The Comic Vision of Anishinaabe Culture and Religion.” American Indian Quarterly, 2002: Vol 26 No 3 pp 436-459.

${ }^{9}$ Fixico, D. (2002). Federal and State Policies and American Indians. In A Companion to American Indian History. Edited by Philip J. Deloria and Neal Salisbury. Malden, Massachusetts: Blackwell Publishers. Page 379.

${ }^{10}$ Young, R. J. (2001). Postcolonialism: An Historical Introduction. Malden, Massachusetts: Blackwell Publishers.

${ }^{11}$ La Duke, W. (1999). All Our Relations Native Struggles for Land and Life. Cambridge, Massachusetts: South End Press.

${ }^{12}$ Indianz.com (2009). Chad Smith: Cherokees of Alabama not legitimate. July 1, 2009.. http://64.38.12.138/News/2009/015317.asp. Retrieved July 2009.

${ }^{13}$ Warren, Stephen. (2000). “The Emergence of Shawnee Nationalism 1800-1870.” Dissertation at the University of Indiana. Ann Arbor, Michigan: UMI. Page 127.

${ }^{14}$ Chalou, George Clifford. (1971). "The Red Pawns Go To War: British-American Indian Relations, 1810-1815.” Dissertation at Indiana University. Ann Arbor, Michigan, USA: UMI

\& Maulden, Kristopher. (2005). "The Arts of Conquest: The Rise of Federal Authority in Ohio 1783-1795.” Dissertation at the University of Missouri, Columbia. Ann Arbor, Michigan, USA: UMI.

\& Wallace, Anthony F. (1999). Jefferson and the Indians The Tragic Fate of the First Americans. Cambridge, Massachusetts. The Belknap Press of Harvard University Press.

${ }^{15}$ Maulden, Kristopher. (2005). Page 25. 
${ }^{16}$ Indians.com (Dec-2000) Clinton signs a final Indian bill. http://www.indianz.com/News/show.asp?ID=law/12292000-1 (accessed April 2009)

${ }^{17}$ Rafert, S. J. (1982). “The Hidden Community: The Miami Indians of Indiana 1846-1940.” Dissertation at the University of Delaware. Ann Arbor, Michigan, USA: UMI.

\& Waters, J. G. (2002). View From the Medicine Lodge. Santa Ana, California: Seven Locks Press.

${ }^{18}$ Harvey, Henry. (1855). History of the Shawnee Indians, From the Year 1681 to 1854, Inclusive. Ephraim Morgan and Sons: Cincinnati, Ohio.

${ }^{19}$ Harvey, Henry. (1855). Pages 164-166.

${ }^{20}$ Warren, S. (2000).

${ }^{21}$ No Author. “A Missionary’s Tour to Shamokin and the West Branch of the Susquehanna 1753.” Pennsylvania Magazine of History and Biography. 1915. Vol 39. No 4. pp 440-444.

${ }^{22}$ Koenig, Alexa and Jonathan Stein. (2007). Federalism and the State Recognition of Native American Tribes: A Survey of State-Recognized Tribes and State Recognition Processes Across the United States. Santa Clara Law Review. Vol 48 pp 153. Page 84.

${ }^{23}$ Coker, William S. and Thomas D. Watson. (1986). Indian Traders of the Southeastern Spanish Borderlands; Panton, Leslie and Company and John Forbes and Company 1783-1847. University of West Florida Press: Pensacola, Florida.

${ }^{24}$ Haggard, Dixie Ray. (2006). “Their Own Way of Warring”: The Making and Persistence of Cherokee and Muscogulge Identity, 1500-1800. Dissertation at the University of Kansas: Lawrence, Kansas.

${ }^{25}$ Piecuch, James R. (2005). Three Peoples, One King: Loyalists, Indians, Slaves, and the American Revolution in the Deep South 1775-1782. Dissertation at the College of William and Mary: Virginia.

\& Sheidley, Nathaniel J. (1999) "Unruly Men: Indians, Settlers, and the Ethos of Frontier Patriarchy in the Upper Tennessee Watershed, 1763-1815." Dissertation at Princeton University. New Jersey. 1999.

${ }^{26}$ Appalachian Summit, (2004). History, Mar 2004. http://appalahciansummit.tripod.com/chapt31.htm

${ }^{27}$ Vickers, Paul Thomas. Chiefs of Nations: Review Copy. (2005-06). "The Cherokee Nation: 1730 to 1839,109 Years of Political Dialogue and Treaties." (www.arkansascherokees.com: IuniversePublishers.)

${ }^{28}$ Dowd, G. E. (1986). "Paths of Resistance: American Indian Relgion and the Quest for Unity, 1745-1815, Volumes 1 \& 2." Dissertation at Princeton University . Ann Arbor, Michigan, USA: UMI.

${ }^{29}$ McMillion, Ovid Andrew. (2003). "Cherokee Indian Removal: The Treaty of New Echota and General Winfield Scott." Dissertation at East Tennessee State University: Johnson City, Tennessee.

30 See tribalcorruption.com 
${ }^{31}$ Peretz, Paul. (1996). The Politics of American Economic Policy Making, $2^{\text {nd }}$ Ed. Armonk, New York. M.E. Sharpe, Inc.

${ }^{32}$ Dowd, G. E. (1986).

${ }^{33}$ White, R. (1991). The Middle Ground: Indians, Empires, and Republics in the Great Lakes Region 1650-1815. New York, New York: Cambridge University Press 1991. Page XIV.

${ }^{34}$ Boucher, C. J. (2001). "The Legacy of Iouskeha and Tawiscaron: The Western Wendat People to 1701." Disseration at the University of Kansas . Ann Arbor, Michigan, USA: UMI. 


\section{Chapter 2 - Amerindian Nationalism: A Theoretical Foundation}

One of the things I hope to demonstrate in this thesis is that the conflicts that occurred in Trans-Appalachia roughly between 1750 and 1830 were primarily a result of incompatible nationalist expressions by Amerindian polities and the British colonies of the Atlantic Seaboard. The contemporary effects can be discernable in current tribal status and condition, and range from unrecognized Diaspora tribal populations, to tribes that are state and/or Federally recognized. Some of these tribes have more recently faced the prospects of termination and integration that would ultimately ensue with the Termination Policy of the Federal government during the 20th Century. ${ }^{\mathrm{A}}$ Whereas, some unrecognized tribes have come through the other end of integration as a result of nonrecognition policies, state actions, and self directed tribal choices, to again emerge with reconstituted communities. One factor in the general status issue is the inequity of the national relationship between status tribal nations with their state and federal counterparts. A clearer understanding of the $18^{\text {th }}$ and early $19^{\text {th }}$ century roots of tribal status policies reveals how current issues came into existence long ago.

\section{Cook-Lynn and Anti-Indianism}

The John Hopkins Guide to Literary Criticism begins its Native Theory review of 2005

by highlighting the dimensions of the contemporary debate regarding tribal identity significant of national North American borders, treaty relations, historical differences, questions of authenticity, colonization, and ideology in line with the tenets of Postcolonialism. The text identifies Elizabeth Cook-Lynn, a scholar of Sioux ancestry, as the foremost advocate of an

\footnotetext{
${ }^{\text {A }}$ Most notably during the 1950s and 1960s.
} 
Amerindian nationalist perspective. ${ }^{1}$ Cook-Lynn’s point of view cuts to the heart of the matter. In "Anti-Indianism in Modern America a Voice from Tatekeya’s Earth" she explains, “... America's First Nations find themselves with the myths of their own national status against a long history of enforced denationalization." ${ }^{2}$ Cook-Lynn extends her analysis by cautiously warning of flighty themes and dialogues with which many Amerindian authors are preoccupied. These include the seemingly never-ending quest for identity and the inevitable helplessness of tribal peoples in the face of institutions that intervene in Amerindian life. ${ }^{3}$

From my perspective, Cook-Lynn’s discussion could have been written in 1830 . Although her Dakota identity is comes from the Northern Plains, her words strikingly and accurately speak to the process and aftermath of westward expansion into Trans-Appalachia. This expansion was in conflict with Amerindian nationalism through the mechanism of a rogue agenda that still seeks to nullify Amerindian nationalism. Cook-Lynn's work cuts through selfserving issues of tribal politics to address the broader concerns of the community at large within the ongoing systematic and literal deconstruction of tribal nations. For Cook-Lynn, this is not an event that is adequately addressed by Postcolonial scholarship, but instead as a largely unrecorded event of genocide. ${ }^{4}$ Using a similar rationale the Arikara/Hidatsa scholar Michael Yellow Bird contends that a general "infatuation” with genocide by civil society in the U.S. can be seen in Indian-themed sports mascots, the media's consistent portrayal of America as benevolent in spite of evidence to the contrary, and the retelling of uncritical histories that ignore or deny genocidal processes. ${ }^{5}$ 
The denationalization of tribal nations occurred in part through the Federal organization of tribes as racial groups rather than as nations. Definition of "blood quantum” and its relationship to government rolls became narrow standards for tribal citizenship. This confused biological with political categories. As a Chickamauga elder once conveyed to me, “The Cherokee were not a race, they were a nation!” He felt that the application of blood quantum criteria was “convenient” for the Federal government. It provided new and abundant opportunities to create division and strife in tribal communities_-abetting a doctrine of "divide and conquer." The terms "full blood" and "mixed blood" are disingenuous, living relics of the Colonial era. They manage to betray the concepts of family, clan, and — in due course - the nation itself. However, these terms served and continue to serve a colonial establishment quite well. In skewing the conceptual and practical implementation of citizenship within reified “nations," they do not emancipate so much as abet processes of domination and control.

\section{Dowd's Paths of Resistance}

Gregory Dowd's Paths of Resistance: American Indian Religion and the Quest for Unity-1745-1815, is a seminal study of Trans-Appalachia. It weighs in on the subject through examination of the ethnic Shawnee, Creek, Cherokee, and Delaware nations in TransAppalachian border regions. Dowd's work is admirable for its scope in considering multiple tribal polities and broad geographic coverage. He states that his dissertation "suggests” and "interprets" the resistance to western expansion with a dual view point: first a "Western" or “modern” point of view to understand tribal discontent from a growing economic dependence on colonial agents. ${ }^{6}$ Here the Amerindian and European regional trade economy was heavily 
invested upon a singular fur or peltry commodity and to a lesser degree-the regional slave trade.

Additional context to consider in reference to the state of affairs that prevailed to the detriment of tribal polities occurred with regime change. At the time of the French and Indian War a strong bi-polarization of European spheres of influence operated in Trans-Appalachia through the British and the French that included considerable political ties to regional Amerindian nations. To say the least, Amerindian participants like their European counterparts attempted to manipulate these trade and security regimes to their advantage. During the French and Indian War the Spanish aligned themselves with the French and while the Spanish had an influence their role was not as decisive. Regional changes turned more so on the British and French and less on Spanish intentions.

For a little over a decade the British held a uni-polar influence, but not a hegemonic influence, on the region. But the region's European element transformed into a multi-polar order after the American Revolution in which the British, the early Colonial Republic, and the Spanish competed for supremacy in the area. Any successful British or Spanish attempt to thwart the expansion of the early Colonial Republic occurred only with the participation of their Amerindian allies. Likewise the expansion of the early American Republic did not occur without vital Amerindian allies. These sorts of political arrangements reflect a changing balance of power that has been described through the political polarities or distribution of power in the region. To 
this point I have not discussed the role of Amerindian nations in the regions balance of power politics. $^{\text {B }}$

In the first point of view, Dowd defines the "nativist," a theoretical individual of indigenous ancestry "who rejected the increasing Euro-American influence in tribal government." ${ }^{\text {7 }}$ The alternative to the nativist, identified as the "accommodationist” (or even “collusionist”) accepted Euro-American influence on tribal governance that allowed individual tribal leaders to expand or maintain their domestic constituency. The latter categories of individuals were more strongly influenced by European authority and increasingly sought to identify with it. However, appeasement or accommodation on the part of the accommodationist was no long-term guarantee of acceptance or reward by the dominant Europeans.

In Dowd's second point of view, presented from an Amerindian perspective, offers a reductionist interpretation of Amerindian resistance movements as journeys in search of "sacred power". ${ }^{8}$ While Dowd recognizes how trade both internally and externally affected tribal polities as it became a tool to undermine Amerindian nationalism; his hypothesis is otherwise chalked with ambiguous abstractions. One could just as easily entertain a hypothesis that states, "Western expansion can be viewed in pre-modern terms that identify manifest destiny as the realization of sacred power. In modern terms, the American Republic’s westward expansion was

\footnotetext{
${ }^{\text {B }}$ Balance of Power politics are significant for describing the distribution of political, economic, cultural, military power classically within the states of the international system but for the purposes of this study the examination is looking at the distribution of power within a regional system with no clearly defined state actor. This sort of distribution of power is typically described by the number of polarities of power operating within the system.
} 
a savage, genocidal precursor to successful state building." However, this point of view is not uniquely indigenous.

The so-called modern nation-state’s development begins with the Treaty of Westphalia in 1648 that ended the religiously driven Thirty Years War. This preceded the American Revolution by only 130 years. ${ }^{9}$ Therefore, modern nation-states were a relatively new phenomenon, appearing early on the scene-and during the process--of Colonial history in North America. ${ }^{10}$ The Westphalia treaty gave rise to principles of state sovereignty, self-determination, legal parity with other states, and supposedly a principle of non-intervention with the affairs of other states. However, none of the treaties associated with Westphalia mention "sovereignty” and they left the German principalities under the authority of the Holy Roman Empire. ${ }^{11}$ Furthermore, the treaty guaranteed rights of intervention to France and Sweden should the treaty be violated. The treaty recognized the rights of both Protestants, including Calvinists, and Catholics. ${ }^{12}$ Significantly, the Westphalia event seems to be another temporary truce among European imperialists in which certain religious rights were obtained. These included the right to worship the same divinity within different theologies but not the right to practice religion outside a God-centered monotheism.

Dowd's study brings much needed clarity on other issues. He identifies the character of intratribal or internal hostilities as an additional precursor dilemma to successful intertribal resistance while also observing intertribal dilemmas. He draws a dichotomy between nativist and accommodationist polities, in which the contrasting dynamics of the two camps strained Amerindian nationalism. Dowd also points out that nativist leaders such as Tecumseh and 
Pontiac operated as the result of a long-standing tradition of intertribal resistance. They did not represent the start of the tradition. ${ }^{13}$

Dowd's commentary stands in contrast to Edmund's provocative article, “Tecumseh, The Shawnee Prophet, and American History: A Reassessment” in which Edmund explains how Tecumseh was a "white man’s Indian.”14 His position is based on the idea that Tecumseh’s leadership represented a centralization of authority as conceptually foreign to Amerindian politics just as intertribal confederations or regimes were. Edmund identifies Tecumseh’s leadership style as one that appealed to whites because it was the kind of solution they themselves would have pursued. ${ }^{15}$ However, Edmund is attempting to co-opt or redefine the very traditions that fueled intertribal nationalism.

Edmund's position can be interpreted as a thinly veiled attempt to undermine a clear expression of Amerindian nationalism. In presenting this, he upholds a scholarly tradition of ignoring or denying certain forms of indigenous political organization. Colonial Europeans never recognized any form of indigenous polity that they did not have a hand in creating. A common error is discrediting the validity of indigenous polities by describing them as something other than "Indian". It is common for scholars articulating a "Postcolonial script" to suggest that the U.S. has had and still has a heavy hand in deciding what is Indian and what is not or who is Indian and who is not. The Comanche scholar Pierotti also notes that, "tribal politics can also often lead to exclusion and termination [of identity] at the personal level an issue often not addressed by scholars because they are recognized by their tribal governments."16 
One common view of Tecumseh as considered by white Americans of his era reported in the Indiana Centinel of Vincennes in December of 1820 records:

He was truly great - and his greatness was his own, unassisted by science or the aids of education. As a statesman, a warrior and a patriot, take him all in all, we shall not look upon his like again.”17

Tecumseh’s appeal to whites rests in his character, charisma, talents, and his choice to stand tall in the face of great odds - all of which have cross-cultural appeal as an archetypal hero. This neutralizes Edmunds arguments on this point. However, many other Amerindian leaders also appealed to colonial figures and populations, e.g. Black Hawk, Sitting Bull, Crazy Horse, Geronimo, etc. Tecumseh was not unique in this respect.

In regards to Tecumseh's cultural orientation he was not an empire builder but rather a consensus builder. He did not use his influence to create an Amerindian empire by conquering villages and incorporating captive males into an army to conquer more villages. He did not seek to build a martial empire or even a chiefdom. He used his skillful oratory to draw like-minded individuals into a consensus that sought to resurrect a cross national, supra-cultural, polycentric, intertribal regime that had collapsed after the failure of the Battle of Fallen Timbers in Ohio and the corresponding defeats suffered by the Chickamauga after the death of Dragging Canoe. Even in his dialogues with colonial authorities such as with Governor, and later President, William Henry Harrison, it is evident that other Amerindian leaders also rose to the occasion and spoke their concerns. His leadership maybe better characterized as primus inter pares: a first among equals. Those who aligned themselves with Tecumseh did so by choice and in so doing supported an intertribal response to prevent the annexation of the remaining Amerindian lands in 
Trans-Appalachia. Tecumseh's success was less than total as many Amerindian nations wholly rejected his efforts, e.g. the slave holding Choctaw swayed by one of their leaders, Pushmataha.

Tribal polities became increasingly polarized along the frontier. ${ }^{18}$ Dowd's proposal of a dual response to the looming border crises is grounded on one side in a nativist camp that rejected foreign interventions that relied on self-directed approaches to reverse the rising tide of "social stratification that accompanied economic dependence" resulting from a one-sided fur trade. "Economic dependence" should not be understood in absolute terms but rather the result of social engineering and political maneuvering to create dependencies. Whether it was Amerindian nations, French, British, or Spanish colonists, they were all dependent upon European trade. Logistic lifelines from European manufacturing and finance seem to have had more influence on outcomes than other local factors. This would remain an issue all the way up to the U.S. Civil War. The other side, an accommodationist camp that remained more traditional as it stressed the individual tribal unit as a point of reference and provided a counterpoint to intertribal associations that benefited from their access to Europeans and Euro-Americans who, in turn, would usually recognize these accommodationist agents as legitimate representatives. ${ }^{19}$ This provided for one method in which tribal authority became more centralized.

This polarization of tribal polities between nativist and accommodationist orientations is frequently the basis for numerous assumptions about Amerindian identity. Dowd considers the "traditional" orientation of the accommodationist camp a "critical issue of Indian identity.",20 What was so critical about it? Dowd contends that the intratribal strife that occurred within individual tribal polities due to trade relations with Europeans was more problematic for 
intertribal unification than was intertribal aggression. Furthermore, Dowd asserts that while tribes did not necessarily share the same political structures, the new corporate structure of intertribal confederation was affected by the same ritual and custom practiced by its citizens before this structure emerged.$^{21}$ Advocates for intertribalism didn’t have to invent a theory of polygenesis. It already existed in the dialogues of their ancestors for decades standing.

Another explanation for intertribal aggression rests in the mutual advantage condition or nature of trade before contact which shifted towards overly hegemonic or monopolistic or oligarchic trade that mimicked the hegemonic aspiring qualities of European trade. In this qualitative shift in trade practices some tribal nations attempted to insert themselves into the structure as brokers or middlemen between other tribal nations and Europeans. ${ }^{22}$ This explanation for intertribal aggression also provides an avenue to explain organizational change in Amerindian society. Not all tribal nations attempted a monopoly on trade but rather sought intertribal partners to negotiate trade reform with Europeans.

Dowd offers an excellent introductory discussion of how "Indian notions of power" and religious affinity may have provided ideological foundations for resistance movements. The indigenous leaders of that era knew they were facing a world of change it was all around them, yet the hallmark of many of those leaders was to address that change by approaching it through their cultural traditions. Cultural traditions that were chalked with not only a repertoire of religious values but also considerations for practical, self-interested statecraft along with an awareness to the high politics associated with a national interest. ${ }^{23}$ Eliades' "The Indian Policy of Colonial South Carolina 1670-1763" records the comments from Edmond Atkin, the acting 
Superintendent of British Indian Affairs of the Southern Colonies, who stated, "No people in the World understand and pursue their true National Interest, better than the Indian.” ${ }^{24}$ In 1755, Atkin pursued a policy aimed at forming a British sponsored intertribal trade and security regime to aid the British in banishing the French from North America. This organization was similar to the Covenant Chain enjoyed by the northern British colonies with the Iroquois League. ${ }^{\mathrm{C}}$ British Indian officials often failed to gain exclusive relationships with tribal nations since Amerindian leadership would attempt to reserve the right to participate in trade relationships with multiple European partners, hence to practice free trade. Furthermore, British officials would also fail to gain the support of their colonies for such ideas. Eliades states that the Colonial governments were opposed to this scheme. ${ }^{25}$ In contrast to Dowd's use of the "nativist" label in the context of Amerindian spirituality, historian David Corkran originally used this label to describe the selfinterest oriented political practices of a Creek headman, The Mortar in the 1967 work "The Creek Frontier." ${ }^{26}$ Corkran portrays The Mortar as high-end user of statecraft whose style relied upon his ability to build practical consensus based solutions that attempted to preempt European designs on the region.

\section{Transformations: Nativists and Accomodationists}

A reexamination of the of the interaction between accomodationist Amerindians and Europeans lay bare any traditional explanations extrapolated from supposed Amerindian cultural

\footnotetext{
C The Covenant Chain's influence did extend to the southern colonies but with the advent of two separate British Indian Departments one for the northern colonies and one for the southern colonies British regime building with Amerindian nations occurred through these two administrative regions with overlapping influence. The Charlestown traders of South Carolina political role had a similar impact on southern tribes as the Albany traders in New York had on the northern tribes.
} 
orientations but rather exposes the risks associated with the interaction. Sara Parker describes an exception to Dowd's interpretation of a traditional approach to identity by accomodationists in Transformation of Cherokee Appalachia, 1755-1808:

Nancy Ward [a noted Cherokee woman] and other Beloveds [national head women] controlled an elaborate network of white men who had married Cherokee women and were acknowledged as Cherokees. Yet these same individuals were on the payroll of James Robertson during the Revolution hired as intelligence gatherers. ${ }^{27}$

Still more, notice Indian agent Hawkins comments before attending his post as Indian agent to the Creek nation:

I believe I shall find no difficulty in establishing a national council, to meet once a year, at the town of my residence, but the expense must be borne by the government, and I think it may be so conducted as not to exceed 700 dollars. $^{28-\mathrm{D}}$

This evidence suggests that the accommodationist camp’s interaction with Europeans challenged and transformed tribal identity at the core in the arena of national politics and in due course ignored domestic tribal boundaries. Cultural implications from foreign influence on tribal polities are apparent. Warren notes how the Post-Removal annuity chiefs or government chiefs on the Shawnee reservation in Kansas continually denied citizenship to tribal applicants and even participated in the termination of another Shawnee band despite protests based on cultural precepts from yet another Shawnee band. ${ }^{29-\mathrm{E}}$ The annuity system also suggests that economic

\footnotetext{
D Jennings (1975, Page 21) reports the position that the transformation of Amerindian society by foreign agency was an unlikely "if not impossible" task unless one factors in the broad and intense decline of indigenous American populations due to disease.

${ }^{\mathrm{E}}$ Post-Removal refers to the timeframe after the Indian Removal Act of 1830 along with the subsequent removal treaties that resulted in the relocation of Trans-Appalachian Amerindian nations to the states of Kansas and Oklahoma. during the 1830s and 1840s.
} 
dependence has been overstated in that the annuity system undermined vigorous Amerindian economic activity resulting in the creation of dependent nations.

Both camps, nativist and accommodationist, reconfigured tribal identities with distinctive differences. The nativist camp did so by finding common ground among tribal traditions and acknowledging the reality that they held a common enemy. While the accommodationist camp did so by absorbing foreign culture indiscriminately. Dowd notes how accommodationists often took up arms alongside nativists when the conditions were favorable to do so, but inevitably utilized their "clout" with Europeans or Americans to cooperate with an agenda that ran counter to the nativist camp. This resulted in a great deal of discord and conflict among the two camps. ${ }^{30}$ This state of affairs suggests that accommodationist leaders occasionally held reservations and doubts about both their European connections and their intertribal counterparts. The accommodationist camp may have preferred not to entrust their future to co-alignment with Europeans, but still saw no other viable alternative. Even so the accommodationist position may simply have been the resulted from a successful colonial parlay for allies. Whether it was French, British, Spanish, or British colonies, they were all adamant about acquiring allies to secure their own interests, or to at least secure the neutrality of tribal polities in order to advance their agendas in the interior. While in some cases Europeans sought the subjugation if not extermination of Amerindian nations that could not be incorporated into their interests or who could not be drawn from their association with other rival Europeans.

In some cases, the reconfiguration of indigenous identity became irreconcilable in that one camp identified with European authority and one camp did not. However, in many cases the 
issue may have been trivial. The means by which colonial authorities secured potentially reluctant Amerindian allies came through various methods, including the wholesale destruction of unarmed and unattended villages in which the adult male population may have been absent (in hunting or other activities). Another means by which European agents may have condition tribal relations in their favor came through medical technology. Sir William Johnson made it a point to address the dangers of small pox to tribal nations by having the Mohawks undergo preventative treatment through inoculations. ${ }^{31}$ This factor I came upon late in my research and requires further investigation.

\section{Intertribal Confederacies and Resistance}

Many scholars regard intertribal resistance as originating in the policy goals of European or colonial agencies rather than tribal polities. Timothy Willig, in "Restoring the Thin Red Line: British Policy and the Indians of the Great Lakes 1783-1812," examines the issue through the perspective of British strategy. He argues that British policy goals of creating security regimes to contest the American Republic were responsible for creating a united intertribal movement. ${ }^{32}$ Willig claims that tribes fought in the War of 1812 exclusively as "British allies"33 and that the Tippecanoe affair in 1811 ended tribal support for nativist unification. ${ }^{34}$ Or one might argue British zealousness or arrogance over their involvement, and their often over stated pledges to their so called Amerindian allies complicated matters greatly to the detriment of Amerindian security.

Warren offers another view in his text "Between Villages and Nations: The Emergence of Shawnee Nationalism 1800-1870." He argues that the destruction of Prophetstown in November 
1811 served to "reinvigorate" the intertribal confederacy as the "Communal bonds in the old Northwest were too strong to relinquish power to any one man...,35 Warren suggests intertribal resistance was identified with public figures like Tecumseh but that their lasting organization relied on more than the leadership or influence of one individual. ${ }^{36}$ He contradicts Willig's British hypothesis but also contends that the fundamental elements to intertribal partnership moved beyond the leadership of single individuals. This supports a hypothesis of Amerindian regime formation based on Amerindian polities and leaders that held similar geo-political views about European intrusions into the region. ${ }^{\mathrm{F}}$

A fine distinction is missing from the dialogue: European kingdoms were at times seeking to bring about collective trade and security regimes in which tribal agents actively participated in such a process. Colonial authorities tried to incorporate tribes into unified partnerships for fear that if they did not, they would be at a disadvantage when other colonial counterparts did. This was not the source of Amerindian nationalist movements, but rather as a byproduct of mutual security and economic interests. Amerindian-European security regimes were born of necessity as each benefited the other in the pursuit of its own agendas. At times their agendas were in line with each other while at other times they diverged. Both European and Amerindian participants in these alliances were aware of their own and their partner's strong points as well as their own vulnerabilities, and each probably viewed themselves in these security associations as the superior party.

\footnotetext{
${ }^{\mathrm{F}}$ Another factor to consider in the success of Amerindian regime building was the relationship between Tecumseh and his brother, the Prophet.
} 
Another example of an international security compact reported by Coker and Watson in "Indian Traders of the Southeastern Spanish Borderlands; Panton, Leslie and Company and John Forbes and Company 1783-1847." They describe the 1793 Treaty of Nogales wherein the Spanish, through the authority of Carondelet, entered into a compact with tribes of the Old Southwest to thwart westward expansion. Carondelet, the local colonial administrator, obligated tribal participants to initiate a war in the event that no agreement could be obtained with the United States over border issues. In contrast, the Nogales Treaty obliged Spain to enter into diplomatic efforts on behalf of Amerindians. The Nogales Treaty also made it possible to end, for a time, the ongoing Creek and Chickasaw conflict. Therefore, these Amerindian-European agreements reflected the national interests of both parties and seem to be a result of consensus efforts. ${ }^{37}$ Richter notes, in "The Ordeal of the Longhouse: Change and Persistence on the Iroquois Frontier 1609-1720," that tribal participation in wars amongst European actors reflected a function of intertribal and cultural processes that valued alliances with Europeans rather than a function of European “squabbling”. 38

\section{Dragging Canoe and Chickamauga Leadership}

Amerindian participants in the Treaty of Nogales included the Chickamauga Cherokee of the Old Southwest. Much more attention has been given in historical literature to intertribal confederations commonly associated with Pontiac, Blue Jacket, Little Turtle, and Tecumseh of the Old Northwest. More attention is given to the Old Southwest in an examination of the forced removal of Trans-Appalachian tribes that began in the 1830s. James Pate’s "The Chickamauga: A Forgotten Segment of Indian Resistance on the Southern Frontier" documents in great detail 
the experiences of the secessionist Cherokees who became known as the Chickamauga associated with the leadership of Dragging Canoe among others. This group served as the cornerstone of resistance in the Old Southwest from 1774 through 1792. Pate outlines the scope of Chickamauga activity from participation in broader Trans-Appalachia native nationalist campaigns that ranged from Ohio, Kentucky, Virginia, Tennessee, to the Carolinas and Georgia. The Chickamauga maintained alliances with the northern tribes of the Ohio River Valley, also with the British and the Spanish through contacts in Detroit, Pensacola, and New Orleans. ${ }^{39}$

Dragging Canoe’s influence was powerful. This is clear from John Brown’s "Old Frontiers," which recounts how former Tennessee governor William Blount, upon hearing of Dragging Canoe’s death in 1790s stated, “Dragging Canoe stood second to none in the Nation.”40 Chief Black Fox, in a foreboding statement, remarked:

The Dragging Canoe ...was a man of consequence in his country. He was a friend both to his own and the white people. His brother is still in his place, and I mention it now publicly... for he promises fair to possess sentiments similar to those of his brother, both with regard to the red and the white. It is mentioned here publicly that both red and white may know it, and pay attention to him. $^{41}$

Dragging Canoe left a powerful impression on colonial America. It was rumored: ...that White settlers and soldiers feared that Dragging Canoe had supernatural powers, and even possibly the ability to resurrect. When Dragging Canoe was buried... it was said that white soldiers confiscated his body, and divided it into two halves...This was done to prevent Dragging Canoe from coming back... ${ }^{42}$

Brent Cox’s "Heart of the Eagle Dragging Canoe and the Emergence of the Chickamauga Confederacy" broadly outlines the political dynamics at work during the era. He makes a distinction between the Old Northwest, where the Iroquois League clashed with the Shawnee for preeminence, and the Old Southwest, in which the Cherokees were initially beset by the designs 
of the Creek, Choctaw, and Chickasaw, noting that these intertribal intrigues occurred in the midst of an expansionary oriented frontier nationalism contrasted against the ineffectiveness of British colonial authority. ${ }^{43}$ Cox offers an interpretation of the Chickamauga resistance as a response to imperialism through "fight, flight, and reform” that represented the "high tide of Cherokee resistance». ${ }^{44}$ Cox demonstrates that military resistance to imperialism was the true nature of the Chickamauga Cherokee polity as opposed to a savage response to imperialism. ${ }^{45}$ What I think Cox is trying to convey is that Chickamauga resistance is significant for an organized effort involving strategic considerations indicative of a modern label as opposed to a primitive uncoordinated belligerent response without considerations for consequences.

Tom Holm, in "American Indian Warfare: The Cycles of Conflict and the Militarization of Native North America," describes differences between modern warfare equated with the modern state and primitive "savage warfare” equated with pre-states. For him, the issue revolves around civilized interpretation and the nature of organization as it relates to intentions along with outcomes. ${ }^{46}$ Both modern terms and putative pre-modern terms must be closely scrutinized. They too easily operate in the self serving guise of one-dimensional state theory. Too often, structural social change is hastily equated with progress or progressive evolution without considering the costs it entails or the impact of change. Holm notes that after John Watts, a successor to Dragging Canoe, established a peace in 1794 with the American Republic, a number of Chickamauga had already migrated west of the Mississippi River. Some continued to migrate 
to Arkansas in 1817 only to become engaged in a long war with the Osage. The Chickamauga became the Cherokee Nation West. ${ }^{47} \& \mathrm{G}$

\section{The Nature of the Amerindian State, Tribe, Nation, Polity}

We have not gone far enough in the analysis to draw too many conclusions but the issues

presented above should be kept in mind by the reader as they progress through the text and conduct their own analysis. We can say that the issue of Amerindian nationalism has been skewed in the literature. The non-critical interpretations of Amerindian motive, interest, and socio-political orientation indicate a gross misrepresentation. Amerindian political discourse was copiously engaging and self-directed with the capacity to introduce their agency into the realm of European political systems. By the same token this prior statement is a fairly accurate statement of European capabilities.

One difference being is the manner in how the internalized agency of the other was effective in securing high priority goals. The effective manner for Europeans was indeed the trade system itself. For Amerindians it was their ability to effect military outcomes between Europeans or directly affect military outcomes between themselves and Europeans. Amerindians could not positively affect the trade system as a tool of agency with Europeans with great measure for its competitive nature placed tribes in direct competition with each other resulting in intertribal trade wars, despite intertribal attempts at trade reform. These dynamics worked to aggravate successful Amerindian nationalism or multi-ethnic nationalism while in turn creating

\footnotetext{
G Holm's abbreviated sketch of Chickamauga polity mistakenly identifies John Ross, Major Ridge, and John Walker as coming into leadership through their associations with Chickamauga Cherokee polity.
} 
paradoxical interpretations or expressions of Amerindian identity. Other constraints working to the detriment of Amerindian society included technological and environmental factors like disease. It should also be noted that as a general principle Amerindian society wanted trade with Europeans-Europeans wanted trade and much more and this is reflected in the high priority goals of their polity. 
${ }^{1}$ Pulitano, E. (2005). Native Theory and Criticism-1. United States. In The John Hopkins Guide to LiteraryTheory and Criticism, 2nd Ed. Edited by Groden, Martin and Szeman. Baltimore, Maryland: The John Hopkins University Press.

${ }^{2}$ Cook-Lynn, E. (2001 ). Anti-Indianism in Modern America A Voice from Tatekeya's Earth. Chicago, Illinois: University of Illinois Press. Pages 86 \& 168-169.

${ }^{3}$ Cook-Lynn, E. (2001).

${ }^{4}$ Cook-Lynn, E. (2001).

${ }^{5}$ Yellow Bird, Michael. (2004). Cowboys and Indians: Toys of Genocide Icons of American Colonization. University of Minnesota Press: Wicazo Sa Review Vol 19 No 2 pp 33-48.

${ }^{6}$ Dowd, G. E. (1986). "Paths of Resistance: American Indian Relgion and the Quest for Unity, 1745-1815, Volumes 1 \& 2." Dissertation at Princeton University . Ann Arbor, Michigan, USA: UMI. Page 4.

${ }^{7}$ Dowd, G. E. (1986). Page 4.

${ }^{8}$ Dowd, G. E. (1986). Page iii.

${ }^{9}$ Beaudry, P. (2003, May). The Treaty of Westphalia, 1648 The Benefit of the Other. Retrieved 2008, from The Schiller Institute: www.schillerinstitute.org/index.html

${ }^{10}$ Young, R.J. (2001). Postcolonialism: An Historical Introduction. Malden, Massachusetts: Blackwell Publishers.

${ }^{11}$ Quoted in New World Encyclopedia. (2009). Peace of Westphalia. http://www.newworldencyclopedia.org/entry/Peace_of_Westphalia. Retrieved 2009.

${ }^{12}$ New World Encyclopedia. (2009). Peace of Westphalia. Retrieved 2009. http://www.newworldencyclopedia.org/entry/Peace_of_Westphalia

${ }^{13}$ Dowd, G. E. (1986).

${ }^{14}$ Edmunds, D. R. (1983). Tecumseh, The Shawnee Prophet and American History: A Reassesment. The Western Historical Quarterly, Vol. 14 No. 3 pp. 261-276. Pages 275 \& 276.

${ }^{15}$ Edmunds, D. R. (1983). pp. 261-276.

${ }^{16}$ Pierotti, Ray. (2010) Conversation with @ University of Kansas. Lawrence, Kansas.

${ }^{17}$ Cultural: Tribal Historic Preservation Office. (2008). Retrieved 2008, from Absentee Shawnee Tribe: www.astribe.com/

${ }^{18}$ Dowd, G. E. (1986). Page 2.

${ }^{19}$ Dowd, G. E. (1986). Pages 5 \& 6.

${ }^{20}$ Dowd, G. E. (1986). Pages 6 \& 7. 
${ }^{21}$ Dowd, G. E. (1986).

${ }^{22}$ Jennings, Francis. (1975). The Invasion of America Indians, Colonialism, and the Cant of Conquest. Chapel Hill: The University of North Carolina Press.

${ }^{23}$ Stevens, Paul Lawrence. (1984). His Majesty's "Savage" Allies: British Policy and the Northern Indians during the Revolutionary War: The Carleton Years, 1774-1778. Dissertation at State University of New York at Buffalo.

${ }^{24}$ Eliades, D. K. (1981). "The Indian Policy of South Carolina 1670-1763." Dissertation at the University of South Carolina . Ann Arbor, Michigan, USA: UMI. Page 231.

${ }^{25}$ Eliades, D. K. (1981). Page 228.

${ }^{26}$ Corkran, David H. The Creek Frontier 1540-1783. Norman: University of Oklahoma Press. 1967.

${ }^{27}$ Parker, S. G. (1991). “The Transformation of Cherokee Appalachia, 1755-1808.” Dissertation at the University of California Berkely. Ann Arbor, Michigan, USA: UMI. Pages 157-159.

${ }^{28}$ Otis Ashmore, J.F. Minis, W.W. Mackall, and T.J. Charlton. Letters of Benjamin Hawkins 1796-1806 Collections of the Georgia Historical Society, Vol IX. Savannah, Georgia: The Morning News, 1916. Page 57.

${ }^{29}$ Warren, S. (2000). "Between Villages and Nations: The Emergence of Shawnee Nationalism 1800-1870." Dissertation at the University of Indiania . Ann Arbor, Michigan, USA: UMI.

${ }^{30}$ Dowd, G. E. (1986). Pages 5 \& 6.

${ }^{31}$ Stevens, Paul Lawrence. (1984).

${ }^{32}$ Willig, T. D. (2003).

${ }^{33}$ Willig, T. D. (2003). Page 295.

${ }^{34}$ Willig, T. D. (2003).

${ }^{35}$ Warren, S. (2000). Pages $61 \& 62$.

${ }^{36}$ Warren, S. (2000).

${ }^{37}$ Coker, William S. and Thomas D. Watson. (1986). Indian Traders of the Southeastern Spanish Borderlands; Panton, Leslie and Company and John Forbes and Company 1783-1847. Pensacola, Florida: University of West Florida Press. Pages 180 \& 181.

${ }^{38}$ Richter, D. K. (1984). "The Orderal of the Longhouse: Change and Persistance on the Iroquois Frontier 16091720." Dissertation at Columbia University . Ann Arbor, Michigan, USA: UMI. Page 63.

${ }^{39}$ Pate, J. P. (1969)." The Chickmauga: A Forgotten Segment of Indian Resistance on the Southern Frontier." Dissertation at Mississippi State University . Ann Arbor, Michigan, USA: UMI. 
${ }^{40}$ Brown, J. P. (1938). Old Frontiers; The Story of the Cherokee Indians from Earliest Times to the Date of Their Removal to the West, 1838. Kingsport, Tennessee: Southern Publishers, Inc. Page 331.

${ }^{41}$ Brown, J. P. (1938). Page 331.

${ }^{42}$ Cox, B. (1999). Heart of the Eagle Dragging Canoe and the Emergence of the Chickamauga Confederacy. Milan, Tennessee: Chenanee Publishers. Page 9 \& 10.

${ }^{43}$ Cox, B. (1999).

${ }^{44}$ Cox, B. (1999). Page ix.

${ }^{45}$ Cox, B. (1999).

${ }^{46}$ Holm, T. (2002). American Indian Warfare: The Cycles of Conflict and the Militarization of Native North America. In A Companion to American Indian History. Edited by Philip J. Deloria and Neal Salisbury. Malden, Massachusetts. USA: Blackwell Publishers.

${ }^{47}$ Holm, T. (2002). 
Chapter 3 - An Analysis of Conflicts, Proclamations, and Consequences

\section{Amerindian-Colonialist Conflicts Over Land}

Bacon's Rebellion of 1676 in Virginia resulted from land grant recipient Nathaniel

Bacon's desire to drive tribal peoples off their lands. However, he did not receive the consent of Virginia Governor Berkeley to do so. When Bacon was denied a commission in the colonial militia he continued working out his plans on his own. ${ }^{1}$ Individuals like Bacon whose lands directly bordered tribal nations often had disputes with tribal officials over hunting areas, trade, domestic animals, and the continual annexation of land by frontier peoples; while individuals further east of the frontier and relatively free of frontier conflict preferred at times diplomatic efforts to resolve conflicts as it was cost effective in contrast to raising militia forces among other reasons. A decade later, Jacob Liesler a prominent New York land developer seized control of colonial New York for three years. An ethnic German immigrant, Leisler rebelled against the authority of England with the support of Dutch merchants and landowners. Land riots occurred in New York and New Jersey. In 1734 a royal surveyor was beaten by rioters pertaining to England's right to the forest in New Hampshire. ${ }^{2}$

England's administration over land was concerned not only with agricultural commodities like tobacco but also the harvesting of timber for its ship building industry. ${ }^{3}$ Exceedingly over time the personal ambitions of individuals seeking to reap the economic benefits associated with the proprietorship of land would forego any structural attempt by imperial authorities to bring or retain North America into an existing integrated political regime. Rather quickly land speculation companies emerged operating in the traditions originally established by colonial charters. ${ }^{4}$ The eminence of land companies and the impact of individual 
land owners shaped land policy. ${ }^{5}$ For example, provincial Georgia and South Carolina were both recipients of regulatory reform from the Crown for landholders in that both colonies were home to a number of individuals that claimed disproportionate amounts of land which they had neither settled nor cultivated for agricultural purposes. ${ }^{6}$ Here the potential for private financial gain interfered with the Crown’s goal of developing their colonies. Land speculation would eventually drive westward expansion in Trans-Appalachia. Overtime the Crown's exclusive right to appropriate lands would continually fall under scrutiny and resentment from it colonial citizens if it had not already become a point of contention. During Bacon’s Rebellion, a contemporary of Bacon provided a critique of the episode and stated that elements of Virginia's citizenry:

...endeavors to get tracts of Land...some take 2000 acres, some 3000 Acres, others ten thousand Acres...many have taken up thirty thousand Acres of Land, and never cultivated any part of it...thereby preventing others seating, so that too many rather than be Tenants, seat upon the remote barren Land, whereby contentions arise between them and the Indians...then they exclaim against the Indians beat $\&$ abuse them. ${ }^{7}$

\section{Colonial Land Companies}

The two principal land companies in colonial Virginia were the Ohio Company and Loyal Company. Their actions and experiences were followed by formation of the Mississippi Land Company. Land companies would organize and lobby the Crown for a grant of land and then use surveyors to mark their allotment. They lobbied and enrolled all sorts of colonial authorities to gain favor for their schemes. They participated in the fur trade and acted as frontier military organizations. Their initial contact with Amerindian authorities were covert as they often hid their real agendas. Land companies had no problem securing title to Amerindian lands 
through deceit as this had been common practice from the inception of the colonies. One of the older methods to defraud an Amerindian from his land was for a local colonial authority to impose a fine on him for some trumped up violation of the law. In which a private citizen would pay the fine on behalf of the Amerindian in return for a mortgage on the Amerindian's property. The altruistic Euro-American citizen would then proceed to foreclose on the property. ${ }^{8}$

\section{The Ohio and Loyal Companies}

The Ohio Company organized by Judge Thomas Lee in 1747 (also the head of the Virginia Company) whose members included George Washington, George Mason, and Governor Robert Dinwiddie. ${ }^{9}$ Other affluent local families and London merchants endowed this land cartel with their membership such as John Hanbury, Thomas Nelson, Colonel Cressup, James Woodrop, Nathaniel Chapman, Jacob Giles, Augustus Washington, George Fairfax, William Thornton, and so on. ${ }^{10}$ The second company was known as the Loyal Company who held close ties with Virginia House Speaker John Robinson. Both companies were staunch rivals. Early in the 1750s, in a gambit in what may be considered one of the opening salvos to the French and Indian War, Governor Dinwiddie dispatched George Washington with Virginia militia to evict the French from the Ohio and more specifically company lands. ${ }^{11}$ Colonial governors at the time had the authorization of the Crown to prepare a defense in the event of war with France but did not have the authority to initiate any acts of aggression.

In 1748 the Ohio Company had acquired claim to 600,000 acres on the Ohio River while the Loyal Company in 1749 secured a grant for 800,000 acres of land while the less substantial Greenbriar Company gained a grant for 100,000 acres. ${ }^{12}$ During the French and Indian War, 
defense appropriations for the Virginia frontier was undertaken in consideration of company and government affiliations. Land companies emerged in other colonies too. The Susquehanna Company became the entity in which colonial Connecticut pursued its claim to the Wyoming Valley (also claimed by Pennsylvania) according to the provisions of its 1662 sea-to-sea royal charter. ${ }^{13}$ Colonial charters as issued from the Crown of England constituted the executive legislative device by which land companies would attempt to fulfill a mandate of sea-to-sea westward expansion across the North American continent. While the companies acted in a classic colonial model whereby they sought to acquire new lands, settle them, and to exploit the economic opportunities presented by their actions they did so under provisions provided by a greater imperial authority. $^{14}$

Conversely, the events of the French and Indian War did not facilitate these sorts of land schemes. In October of 1758, colonial Pennsylvania entered the Treaty of Easton with the Shawnee, Delaware, and other Ohio tribal nations. Simply, Pennsylvania agreed not to expand its settlements beyond the Allegheny Mountains upon the conclusion of the war so long as the tribal nations did not aid the French during the war. By October of 1761 Colonel Bouquet, Commandant at Fort Pitt (Pittsburgh) ordered a declaration based on the Treaties of Easton that forbid hunting and new settlements by whites in the western country providing exceptions by the authority of colonial governors or the commander-in-chief. The proclamation was not received well in Virginia for many Virginians were holding patents to lands under the authority of His Majesty, nor was it popular among settlers who seemingly fought the war with the expectation of acquiring their own lands in the interior for services rendered. ${ }^{15}$ 
Bouquet's proclamation also threatened the Virginia’s landed gentry’s long standing tradition of land acquisition as it had been officially altered. ${ }^{16}$ Nevertheless, upper class planters, in addition to petitioning His Majesty, attempted to continue to maneuver through the exceptions provided by Bouquet's proclamation to secure the possession of large frontier tracts of land. These large tracts of land as with previous land development practices were to be populated with slaves and "landless" tenants or indentured servants. ${ }^{17}$

\section{The Mississippi Company}

Following the cession of past and any future claims to the entire Trans-Appalachia region by France at the Treaty of Paris new land companies emerged; for one-the Mississippi Land Company. Organized by planters and merchants from Maryland and Virginia that again included the membership of the Virginia Lee family and of course George Washington. ${ }^{18}$ By the time of the American Revolution, the cartel of land companies entertained designs that carved up nearly the entire interior region as far west as the Mississippi River.

The Mississippi Company sought a colony along a cross section of land broadly ranging across the drainages of the Mississippi, Ohio, Wabash, and Cherokee Rivers consisting of an estimated 2.5 million acres. Land distribution in accordance with such huge tracts of land would conveniently serve to reinforce the colonial social order with those holding rights to land sitting at the top of the political/economic chain. Further company officials surmised that the Treaty of Easton had no bearing on their designs, as the treaty was only concluded with a limited number of Ohio River Valley tribal nations, long term plans involved the settlement of the vast land tract with new European immigrants. ${ }^{19}$ Returning to the subject presented by the Treaty of Easton, 
Colonel Thomas Cressup went about trying to recruit Colonel Bouquet into the Ohio Company probably as a means to gain Colonel Bouquet’s favor. But Bouquet went about reminding Cressup that the Treaty of Easton had indeed been accepted and recognized by the English ministry at home and hence the colonies were bound by its restrictions on settling lands in the Ohio territory until the tribal nations of Ohio sanctioned such actions. ${ }^{20}$

By this time the Lords of Trade and Plantations had issued orders that no grants of land were to be authorized regarding the Ohio region. The matter was a delicate one with potentially severe political ramifications. Hence, General Amherst (notorious for his 'small pox decision' during hostilities with tribal nations at Fort Pitt) warned Colonel Bouquet to shun measures that would give the colonies an opportunity to find fault with the military's presence on the colonial

frontier for reasonably it might provoke unwarranted hostilities. ${ }^{21}$ Therefore the Mississippi Land Company’s labors to secure a land grant from his Majesty were fruitless and further complicated by the issuance of the Royal Proclamation of 1763. As late as 1767 Mississippi Land Company officials were recommending to company share holders the recruitment of influential British citizens to carry out a successful lobby with the Crown to acquire the land grant they so desired. $^{22}$

\section{Amerindians and the Royal Proclamation of 1763}

Beyond the land speculation companies and their ties with bankers and other influential peoples, the Indian Agents of North America also had a substantial role in the demise of the administration of the Royal Proclamation of 1763. The Northern Department of Indian Affairs headed by Sir William Johnson under pretext of bureaucratic duplicity out rightly disregarded 
the policy course prescribed by the Proclamation and implemented it where his personal interest and the private interests of other individuals overweighed the broader public interest addressed by the Proclamation; and I am including the native interior as part of the public interest. On the other hand, the Southern Department of Indian Affairs seemingly tried in earnest to implement the designs of the Proclamation as Edmund Atkin originally provided a report with recommendations to Lord Shelburne during Atkin's administration over the Southern Indian Department. ${ }^{23}$ But the Southern Indian Department was not without its problems either for its jurisdiction also hosted a number of land companies, speculators, and illegal land squatters that it had to contend with, but this office seems to have been more concerned with fulfilling its mandated duty. But at times the Southern Department's administrators were less than genuine.

In November of 1763 John Stuart, the new superintendent of the Southern Indian Department organized the Augusta Congress attended by the governors of the four southern colonies and the corresponding five southern tribal nations including the Catawba, Creek, Cherokee, Choctaw, and Chickasaw. The purpose of the conference was to confer upon the terms of trade as well as the confirmation of territorial dispositions for the creation of a boundary line. The conference also provided for a public order in that all settlers residing on tribal lands were obligated to return to their colonies. ${ }^{24}$ The invitation to the Augusta Congress stated;

As an incontestable Proof of his Majesty's most benevolent and upright Intentions and Disposition towards you and the Other Indian Nations, I enclose you a copy of Orders which he has lately sent to his Governors in America relating to your Lands; and which I am ordered to Communicate with You, that you may cause them to be read and Published thro'out your Nation, to the End that all men may know his Majesty['s] determines resolution of maintaining you and the Other Indian Nations in Your just Rights and Priviledges and Observing inviolably his Engagements. ${ }^{25}$ 


\section{Antecedents: The Proclamation of 1761}

The Crown had actually issued a proclamation in December of 1761 that declared a boundary line of sorts which required illegal land squatters to be removed from Amerindian lands. It was available to the colonies six months prior to the Royal Proclamation of $1763 .^{26}$ As far back as the mid-1750s provincial New York and Virginia were under orders to end the practice of purchasing lands from tribal nations by private citizens who had neither a license nor sanction form duly appointed agents of the Crown. But the colonial governors or commander in chief were still able to approve land acquisitions, however, as long as they met these requirements:

1) The lands in question had to be formally surveyed and recorded.

2) An interpreter had to be present at the negotiations.

3) A land acquisition cap of one thousand acres was to be observed.

4) The survey itself had to be confirmed through written or verbal certification by the tribal counterparty in the transaction. ${ }^{27}$

The 1761 Proclamation “Settlements Interfering with Frontier Indians Forbidden” provided punitive measures in that colonial governors and other royal agents would stand to lose their office if they proceeded with any new grants of land. This proclamation further provided for the prosecution of individuals who were currently holding lands without a license. ${ }^{28}$

The Southern Indian Department, in July 1763, sent copies to the southern tribal nations in advance of the formal invitation to the congress. ${ }^{29}$ Even though British intentions were clearly 
articulated not every issue was resolved without some tribulation. The Creek Nation had continued their commercial relations with the French during the war. Some Creek factions were active allies of the French during the war. ${ }^{30}$ The Creek Nation intended to maintain relations with the French and Spanish. The Creek Nation was therefore suspect of the English attempt to monopolize trade relations so a number of chiefs failed to attend the Augusta Congress; in this manner Stuart initially failed to gain full consent over the new territorial dispositions confirmed at the congress. ${ }^{31}$

While English authorities might have considered their victory in the war a legitimate basis to exclude the French and Spanish from the activities on the continent it was probably a mistake to attempt a trade monopoly with the tribal nations of the interior. This action may have been interpreted or received as an excessive measure or instep on the authority of tribal nations. In theory, the English did create an open trade system in which anyone who qualified could gain license to trade under the terms of the Royal Proclamation as long as they were peddling English manufactured goods. ${ }^{32}$ The system was designed to operate under the tenants of Mercantile Theory in which colonies and tribal nations were to serve the purpose of providing the mother country with raw materials to support the domestic manufacturers and then to act as the primary consumer of the manufactured goods derived from the mother country. ${ }^{33}$ This sort of economic motivation is a definitive feature of the imperial scope of the Royal Proclamation in that it was constructed to serve the interests of the Crown and the broader empire rather than the stand alone interests or the self-perceived needs of the colonies themselves. ${ }^{34}$ The fur trade from Canada alone would eventually produce 200,000 lbs. sterling in annual revenue. ${ }^{35}$ 
The trade system was based heavily on credit facilities. Merchants would acquire their goods from firms in London on credit. These goods would then be forwarded to trade posts. In the spring, a trader would bring his furs to the trade post and acquire a new bundle of goods on credit and set out again in the fall to obtain more furs from tribal hunters. The credit facility reached as far as the hunters who received goods from the trader also on credit. The trader often used the proceeds from his spring sales at the trading posts to pay for the previous season's goods. Great financial success would be obtained by large fur trade companies who directly partnered with traders. $^{36}$

\section{The Royal Proclamation of 1763}

The Royal Proclamation of 1763 outlined the administration of England's North American colonies, and extensively increased the role of the English Parliament in this governance. ${ }^{37}$ In this respect the Royal Proclamation sought to exert imperial control of the colonies and retain their status in the formal global order to serve in the broader hegemonic interest of British Imperialism. ${ }^{38}$ Henry Ellis, former governor of provincial Georgia, is responsible for the original draft that was submitted to the Board of Trade and Plantations. The document was titled Hints relative to the Division and Government of the conquered and newly acquired Countries in America. ${ }^{39}$

Lord Shelburne mulled over the document for weeks while working in close association with Maurice Morgan. Morgan considered the role of colonists in North America as minor organizations in the greater scope of the empire’s economic trade. Morgan felt colonial sea-tosea charters should be abandoned while taxes on existing trade should be utilized to finance the 
operation of colonial governance in order to consolidate the gains achieved by the Seven Years War. ${ }^{\mathrm{A} \&}{ }^{40}$ Morgan further advocated military escalation on the frontier for the purpose of protecting Crown interests:

...under the pretence of regulating Indian trade a very straight line be suddenly drawn on the back of the colonies... The provinces being now surrounded by an army, a navy, and by hostile tribes of Indians... and being thus limited and distressed in their finances and wanting an executive for the purpose of resistance, it may be time...to exact a due deference to the just and equitable regulations of a British parliament. ${ }^{41}$

In August of 1763, during the creation of the Royal Proclamation, Pontiac of the Ottawa, the Seneca of the Iroquois League, the Shawnee and Delaware of Ohio, and elements of the southern Creek Nation among others began a border war to expel the British from their newly acquired military and trade posts. The Cherokee had formerly been involved in a war with England over its borders that served as a sort of preamble to the broader escalation of conflicts emerging in the frontier lands of the interior country after the French had been defeated. While the tribal nations were probably not privy to the on goings of the British government they were nevertheless growing weary of the British occupation of forts in their territories. Hoping to defer future conflicts the Board of Trade and Plantations, a policy arm of British foreign affairs, insisted upon the public transmission of the Royal Proclamation to relieve the tribal nations of their ongoing troubles with settlement into their territories. ${ }^{42}$ However, other events, such as the resignation of Lord Shelburne an acting Lord of Trade would continue to delay its release. ${ }^{43}$ The

\footnotetext{
${ }^{\text {A }}$ The original charters gave each colony differential rights and the cancelation of the charters would provide for the opportunity to create a uniform colonial system under the discretion of British Parliament.
} 
Royal Proclamation was eventually completed in October of 1763 under the direction of Lord Halifax. $^{44}$

The Proclamation of 1763 established an Indian dominion or reserve west of the Appalachian Mountain Range while also prohibiting any land grants into the area except by the direct authority of the Crown of England. This act stood in direct opposition to the traditions of the early colonies where New England and New York for example operated under the directive to pursue the acquisition of large tracts of land from tribal nations. ${ }^{45}$ Tribal nations of the interior had no direct input in the articulation of the Royal Proclamation-their input would come later at conferences where terms of trade and the actual boundary line were negotiated between agents of the Crown and tribal agents. In addition, a regulated trade system was authorized for use within the native territories that incorporated licensing and taxing considerations. ${ }^{46}$ Four new colonies were created-Quebec, Eastern/Western Florida, and Grenada in attempt to control or at least influence the direction of future colonial settlement. ${ }^{47}$ The Proclamation stipulated the form of civil administration and judicial services for the new colonies. In addition it immediately opened the new colonies for settlement; although the Proclamation did not consider nor address the former French communities in the Illinois region of the interior. ${ }^{48}$ As a final point, the Royal Proclamation in terms of the western legal tradition did acknowledge a "new policy" in which indigenous claims to lands were "recognized as valid” by the British government. ${ }^{49}$

The boundary line, according to Lord Shelburne’s personal notes was to generally apply with noted exceptions. Exceptions included Cherokee, Creek, and Catawba claims to lands on the east side of the Appalachia Mountains, the Six Nations claim on the Susquehanna River, the 
military and trade complex at the Forks of the Ohio River, and the settlements already having occurred under the governorship of Virginia. Otherwise, no other exceptions were to be applied to the issue of the boundary line. These limited exceptions were based on the Treaty of Lancaster, $2^{\text {nd }}$ Treaty of Easton, and the Treaty of Detroit. ${ }^{50}$ One specific case or exception provided by the Easton Agreements occurred when a group of lawyers representing a band of Delaware in September of 1758 arranged the release of title to Delaware lands and obtained land in provincial New Jersey for the Delaware; although these lands would eventually be forfeited too. As late as the 1950s the Sand Hill Band of Delaware was recorded as to still be residing in the New Jersey coastal regions. ${ }^{51}$ Today at least one Delaware band in New Jersey has obtained state recognition. ${ }^{\mathrm{B}}$ These exceptions are unique as they stand in contrast to the typical western movements of tribal populations. By November of 1763 Thomas Gage sent copies of the Royal Proclamation to the commanders of the colonial and frontier forts ordering the dissemination of its contents. ${ }^{52}$ On a side note, Canassatego an Iroquois League representative during the discussions at the Lancaster Treaty urged the representatives of the British colonies to enter into a permanent union or confederacy in the same manner as the Iroquois had as to achieve the same sort of power enjoyed by League member nations. ${ }^{53}$

Not surprisingly, the Royal Proclamation of 1763 was not a perfect instrument of imperial policy. For example, this proclamation included a provision permitting Colonial Governors and British Officials in the Army to provide land grants beyond the boundary line to soldiers and officers who served during the French and Indian War. Arthur St. Clair, a former

\footnotetext{
${ }^{\text {B }}$ See www.nanticoke-lenape.org
} 
British Army lieutenant, received a grant in proximity to Fort Ligonier, an auxiliary post in the Fort Pitt trade and defense network. This provision in all likelihood upset the landed gentry whose own plans of land acquisition had been thwarted by the Royal Proclamation. The Penn family alone who formerly had a monopoly on the buying and selling of land in Pennsylvania was locked out by the new regulations. Soon enough the military grant provision of the Proclamation would be abused. For example, Lord Dunmore of Virginia used the military provision to provide land grants to civilians such as the noted Thomas Jefferson. ${ }^{54}$ Such uses of this provision undercut the integrity and purpose of the royal decree.

The Royal Proclamation served as a primary factor behind the Revolutionary War movement through its policy of terminating territorial expansion. ${ }^{55}$ Individuals such as George Washington never really conceded to the authority and designs of the Proclamation and insisted that the Ohio region remained within the bounds of Virginia's colonial charter. ${ }^{56}$ Revolutionary War advocate, Patrick Henry bought the rights to thousands of acres in Kentucky and advocated “coerced” measures to modify land regulation. ${ }^{57}$ Officials, such as Virginia’s Lieutenant Governor protested directly to the Board of Trade and Plantations while the Governor himself responded by resisting the implementation of the Proclamation's decrees. ${ }^{58}$ Speaker of the House of Burgesses-Virginia, David Robinson noted the uselessness of land claims as the land was “...given as compliment to our good friends and faithful allies, the Shawnee Indians."

Pressure would continue to mount against the authority of the Proclamation as more companies were organized. Benjamin Franklin and other family members in 1763 formed the Illinois and Indiana land companies, however, without success as they were not able to obtain 
grants of land despite far-reaching lobbying efforts with the Crown nor could they gain

compensation for trade losses amassed during the French and Indian War. ${ }^{60}$ Indian agent George Croghan sought to petition the Crown to adjust the boundary line through his affiliation with the Indiana Company but to no avail. ${ }^{61}$ In any event, in violation of the Royal Proclamation of 1763, in 1768 the Indiana Company entreated with the Six Nations to obtain a 2 million acre tract below the Ohio River for compensation due to the losses incurred by the company's trade activities during the border wars of $1763 .^{62}$

\section{The Future Management of Indian Affairs Plan (1764)}

By 1764, the Future Management of Indian Affairs Plan was introduced by the Board of

Trade and Plantations to assist in the administration of the Royal Proclamation of 1763. The plan articulated new trade and land regulations while also, in theory, centralizing the management of Indian affairs with the Northern and Southern Indian departments, thus relegating colonial governments and military administrators to a subordinate role. The plan also placed restrictions on Indian agents who were forbidden to conduct trade directly or as representatives of other parties with tribal nations. The same rationale was applied to members of the military. ${ }^{63}$ Some members of the military began their own land companies, such as General Phineas Lyman’s land company, the Military Adventurers. ${ }^{64}$ Regulations were enacted in consideration of future land purchases by corporations with the vested authority of the Crown within the geographical confines of established colonies. ${ }^{65}$ However, for the time being:

...Article 41 [of the 1764 Plan] prohibited any person, society, corporation, or colony from acquiring any property in Indian lands, either by purchase or other conveyance from the Indians...66 
As with the Royal Proclamation of 1763, the Southern Indian Department under John Stuart went about the business of addressing the contents of the 1764 Plan to create a boundary. However, Sir William Johnson, head of the Northern Indian Department continued with his bureaucratic craft as he was accountable for many of the tenants contained in the plan ${ }^{67}$ - Sir William himself was a member of the Illinois Land Company. ${ }^{68}$ The Illinois Land Company also had the backing of New York as the governor was also a company shareholder. ${ }^{69}$ The Board of Trade and Plantations sought to avoid any renewed warfare with tribal nations. ${ }^{70}$ Warfare on the frontier was highly disruptive to the lucrative fur trade and for other issues such as England's control of her colonies. ${ }^{71}$ The new plan centralized all negotiations between tribal nations and colonial authorities through the Indian Departments. However, the British Parliament undermined the plan by failing to enact a tax on trade conducted with the tribal nations of the interior therefore, failing to create an independent source to finance the operations of the Indian departments. The 1764 Plan was also undermined by members of the Board of Trade and Plantations whereas Lord Halifax singularly advocated for a standalone administration of Indian Affairs. $^{72}$

Basically at issue was the creation of an independent regulatory agency that was insulated from the influence of local colonial authorities. What was at stake was the creation of a fortified foreign affairs department to maintain relations with the indigenous population of North America. Such a department would respond to the Crown's imperial orders through a select number of administrators compared to weak foreign affairs departments that essentially acted as front organizations for the interests and lobbyists of trade companies and land speculation 
companies at the level of the colony. Except in this case, the plan was foiled as the lead administrator in the Northern Indian Department— Sir William Johnson, was performing his duties under the influence of land speculators. In classic political science terms the issue at hand was regulatory capture in which a regulating agency cannot successfully carry out its mission because its purpose has been subverted through the influence of those it is designed to regulate.

To correct this situation, in the late spring and early summer of 1765, John Stuart of the Southern Indian Department held another congress, whose goal was to promote peace, trade, and the demarcation of a new boundary line. Stuart advocated the establishment of a trade tax to be exercised exclusively within the confines of tribal jurisdictions. Prohibitive regulations were also created regarding the sale of rum and armaments. Despite Stuart's efforts, the colonies would not observe his administration's goals and continued their trade with tribal nations to the detriment of the centralized trade system established by Stuart. They accomplished this through selling goods at cost, thus undercutting the pricing provided by licensed traders. By 1766 Lord Shelburne near his final days as an acting Secretary of State authorized Stuart to enact any provisions in line with the Rationale of the Royal Proclamation of 1763. Stuart responded with tougher trade licensing requirements—-with the exception of the governor of Virginia, colonial governors responded with surface compliance. ${ }^{73}$

The labors of individuals like agent Stuart and Secretary of State Lord Shelburne were immediately run amuck by the Chancellor of the Exchequer, Charles Townshend who ordered an abrupt military withdrawal from the Appalachia frontier along with a round of investigations into colonial finances, land settlement issues, and trade. In defiance, Shelburne, sought to uphold the 
existing framework of the Royal Proclamation of 1763 by ordering a stringent adherence to its tenants and the formation of a boundary line. In the fall of 1767, the Board of Trade and Plantations began formulating a plan that would grant authority over Indian affairs to the colonial governors while authorizing three additional colonies on the Illinois River and at Detroit with the intention of maintaining only strategic military trade complexes to lessen the costs of operations in the interior. By winter the plan was abandoned. ${ }^{74}$ Speculatively, this plan represented the interests of London financiers, colonial trade companies, and the land speculators.

To compound the issue of territorial expansion addressed by Royal Proclamation, during the same winter colonial newspapers began running articles describing the fertile lands of the Ohio Valley, in effect promoting westward migration and raising the expectant fervor of settlers wanting to partake in the great move west. ${ }^{75}$ In consequence the Braddock and Forbes Roads, military and trade routes, began to be filled with settlers seeking new fortunes. ${ }^{76}$ Within the year the Board of Trade and Plantations adopted convenient parts of Lord Shelburne's plan and fore went the fundamental elements of his policy centered on establishing a firm boundary line. ${ }^{77}$ In all, these events had a destabilizing effect on the frontier and on the boundary line that separated colonial populations from tribal populations. These various plans seem to represent the compromises and struggles between the expansionary and non-expansionary interests in British government.

\section{Consequences: The Walpole Company}

Eventually the Crown would authorize certain land speculation designs west of the Appalachians. By 1766 the Walpole Company was organized and lobbied for a 2.5 million acre 
tract of land that was eventually approved by the Crown in August of $1772 .^{78}$ Land speculation fever involved a consortium of lobbyists in London who even resorted to bribery of cabinet officials as a means to achieve their goals. In due course Lord Shelburne would be relieved of his duties in colonial matters either because the political maneuvering of land speculators cast an unfavorable hue on his policies or maybe because his policies didn’t favor the land company’s interests enough. ${ }^{79}$ Lord Shelburne's own thoughts on the matter seemed to sway. Lord Shelburne’s removal would only provide a temporary respite. The Mississippi Company renewed its efforts as a Walpole Company rival but achieved little. ${ }^{80}$ Implementation of the Proclamation of 1763 was compromised from the outset, because of the differences between those in British government who favored expansion and non-expansion.

The Walpole land company was led by London banker, Thomas Walpole who in consort with Benjamin Franklin, a representative of Pennsylvania, actively pursued the company’s interest with the Crown. Simultaneously in colonial America, Sir William Johnson and New Jersey Governor Franklin, the son of Benjamin, worked towards the company’s goals by dispatching Indian agent Croghan to negotiate with the tribes of the Illinois region. The final goal of the Walpole Company was to gain control of the entire territory between the Ohio River and the Allegheny Mountains, a northern range of the Appalachians, and establish another Crown sponsored colony. The company recruited a number of influential individuals to aid in its efforts and even managed to gain hesitant consent from Lord Shelburne to proceed with its plans. Nevertheless, the company experienced stringent opposition from the Board of Trade and Plantations that was now headed by Lord Hillsborough. Hillsborough surmised and suspected 
that the opening of the Ohio region to settlement would attract an enormous influx of Irish immigrants. Hillsborough was further concerned that a manufacturing industry could develop at the expense of England's domestic industry. Hillsborough also described the potential expense of maintaining a colony so far inland from the coastline. ${ }^{81}$

\section{The Treaty of Fort Stanwix (1768)}

The basic structure of the Proclamation of 1763 endured an unsound tenure as events like the 1768 Treaty of Fort Stanwix in effect nullified the Proclamation’s goal of bringing stability to the region by integrating the former colonies of New France, Amerindian society, and the British colonies under the administration of the empire. Nonetheless, the Royal Proclamation of 1763 was still being cited for the basis of royal directives to colonial governors all the way up to the American Revolution. ${ }^{82}$

In 1768, behind the backdrop of irresolute and chaotic colonial policy, Sir William Johnson of the Northern Indian Department set about obtaining a huge land cession on behalf of his own interests under the guise of creating the sort of boundary line dictated by the Royal Proclamation of 1763 and the Plan of 1764. Sir William held intimate relations with the Mohawk of the Iroquois Confederacy, in large part because he was married to the sister of Mohawk Chief Joseph Brant. ${ }^{83}$ Mary Brant and Sir William would have eight children. ${ }^{84}$ Sir William proceeded with his extension of the boundary line by relying on claims of the Iroquois League to the whole interior stretching from the Mississippi River to the Appalachian Mountains. The Iroquois claims, whether accurate or not, would serve to legitimize Sir William's land transactions. ${ }^{85}$ 
At the Treaty of Fort Stanwix in November of 1768, at Rome, New York-Sir William exceeded the boundary line authorized by Lord Hillsborough by going as far as the Tennessee River. ${ }^{86}$ So the boundary line issue fell into disarray as the northern Stanwix Line did not fall into alignment with the southern line created by Stuart and the Cherokee just a month earlier with the Treaty of Hard Labour; a line intended to settle territorial dispositions between Virginia and the Cherokee. ${ }^{87}$ Lord Hillsborough's original authorization would have brought these two lines into agreement at the mouth of the Kanawha River. The two largest beneficiaries of the Stanwix negotiations were the Penn family who obtained the outstanding lands according to the precincts of their colonial charter; and the Indiana Company who gained two million acres plus in the Ohio River Valley. As a side note, due to his efforts in the affair, Indian agent Croghan was awarded a 200,000 acre grant at Fort Pitt that is today known as downtown Pittsburgh from one of the companies he was involved in. ${ }^{88}$ The Stanwix Treaty also observed the sovereign rights or hegemony of the Iroquois League over other tribal nations residing in the ceded lands. The Delaware and Shawnee Nations rejected League claims of sovereignty over their affairs and the Treaty of Stanwix itself. ${ }^{89}$

In a politically motivated provocation, representatives of Virginia were disregarded at the negotiations despite their presence. ${ }^{90}$ Nevertheless Virginia would gain the Kentucky region for settlement due to the Tennessee River extension. ${ }^{91}$ This area south of the Ohio River included hunting grounds claimed by both the Shawnee and Cherokee Nations. In turn, the Southern Indian Department would be forced to seek new land cessions to form a coherent boundary line as the Stanwix debacle led to new settlements in the river valleys of Watauga, Holston, and 
Clinch. ${ }^{92}$ In later years, these settlements were heavily contested in open warfare by the Chickamauga.

The Illinois Land Project (1772)

The Crown's goal of establishing a boundary line was further damaged by the continous maneuvering of land company officials and their allies holding positions in colonial governments. By 1772, the Illinois land project was approved against the recommendations of Lord Hillsborough who understood that the lands in question were within the jurisdiction of Virginia and within the jurisdiction of tribal nations. Benjamin Franklin had won the Crown's favor. Franklin's success can be attributed to the company's agreement to pay a onetime fee for the land, to collect land taxes, and to provide for the cost of maintaining a local colonial government. Lord Hillsborough resigned over the matter and was replaced by Lord Dartmouth. ${ }^{93}$ Lord Dartmouth was himself the recipient of a land grant in $1770 .^{94}$

Almost immediately the Dartmouth administration ran into trouble with the ambitions of Virginia’s Governor Lord Dunmore. Dunmore had requested a personal land grant totaling around 100,000 acres, but was denied. Governor Dunmore also received communications from the Crown directing him and all other colonial governors to cease approving new land patents or initiating new land surveys according to the tenants of the Royal Proclamation. Dunmore ignored these instructions and continued the work of issuing new land surveys and grants by enlarging the counties in western Virginia. Dartmouth further instructed Dunmore to stop issuing grants of land to Virginia's veterans of the French and Indian War who as local provincial militia soldiers were not entitled to the same benefits as soldiers who served in an official capacity as members 
of the Crown’s army; again a position determined by the Royal Proclamation of 1763.

Dartmouth continued such actions by nullifying Virginia land grants and placing any open lands on the auctioneer's block in which revenues from sales would be deferred to the Crown. ${ }^{95}$ In the same year, Dartmouth approved the formation of a new colony to be known as Vandalia that was situated south of the Ohio River and north of the Greenbriar River, though the project, the Walpole Company project, ultimately failed. The project had been discussed with the southern tribal nations at the Augusta Congress. ${ }^{96}$ Lord Hillsborough was somewhat vindicated as the Walpole grant that had been authorized by the Board of Trade in 1772 was never issued by the Crown as it was tied down with conspicuous administrative delays ${ }^{97}$ In this manner no new colonies were chartered by the Crown of England except for the four colonies enumerated in the Royal Proclamation of 1763.

Events continued to destabilize the entirety of the border regions. In 1773, the Illinois Company reached an agreement with the Illinois Nation for land north of the Ohio River and East of the Mississippi River. In due course the Illinois Company and the Wabash Company would merge their operations and lay claim to over 50 million acres. ${ }^{98}$ In the meantime, Governors Dunmore and Penn, using militia forces, began fighting over land claims in the Ohio region in which Pittsburgh served as a focal point of the contest. Lord Dunmore ordered militia forces into Pittsburgh and initiated the formation of a local government. In doing so, Lord Dunmore made a claim that the region rested under Virginia’s jurisdiction. Dunmore also sought to apprehend and take into custody Arthur St. Clair, a military agent of Pennsylvania. ${ }^{99}$ During the summer, Virginian George Washington, in a Maryland publication, began advertising land 
for sale in the Ohio River Valley. ${ }^{100}$ Late in the year the Virginia High Court of Chancery nullified all claims that impeded upon the territory of Virginia according to the constructs of his Majesty’s imperial government. ${ }^{101}$ Soon enough, events like Pontiac’s War, the latter stages of the Revolutionary War and further legislative attempts by the Crown to place restrictions on land acquirement would put a temporary end to the grand designs of land speculators.

\section{The Quebec Act (1774)}

If there is any doubt to the Crown's commitment of prohibiting new colonies it was removed by the Quebec Act. The Quebec Act of 1774 put an abrupt halt to existing land acquisition operations. The passage of the Quebec Act by British Parliament placed the territory of the Illinois region as far east as the Ohio River under the civil jurisdiction of British Canada denying the land companies access. But the Quebec Act does not sufficiently address the nature of this civil jurisdiction in regards to the Amerindian nations residing in those lands but rather addresses the French inhabitants. Accordingly the act severely reduces the lands reserved to Amerindians by the Royal Proclamation of 1763, however, it is unlikely that this stop gap legislation would have been the final determination regarding the matter. Furthermore, many Amerindian nations in this sub-region had historically held amiable relations with the French.

The Rationale for the Quebec Act can be traced as far back as 1763, when Charles Wyndham the $2^{\text {nd }}$ Earl of Egremont and then acting Secretary of State for the Southern Department in communications with the Board of Trade and Plantations stated that the interior of North America should be left to the tribal nations who inhabited it, but that a civil jurisdiction should be erected over the territory and assigned to Quebec. ${ }^{102}$ The Quebec Act, like the Royal 
Proclamation of 1763, effectively amended colonial charters such as Connecticut's whose previous western boundary was defined as the Pacific Ocean. Another significant factor involved in the passage of the Quebec Act was the influence asserted by the fur trading houses of Quebec and Montreal who wanted to lock out their competitors in Albany, New York. ${ }^{103}$

New land companies ignored the Quebec Act and began direct negotiations with tribal nations for the purchase of new lands. One such company, the Henderson or Transylvania Company negotiated a land sale involving the majority of the Kentucky region with the Cherokee Nation. ${ }^{104}$ This agreement would lead to serious divisions in the Cherokee Nation, but perhaps the leadership of the time felt the Kentucky region had already been compromised by the previous Stanwix Treaty and thought this was an opportunity to receive compensation for something it could not undo without conducting a costly war.

Henderson, who had consulted with Boone [a company agent] and reflected deeply over the subject, foresaw that the Western land, though ostensibly thrown open for settlement by the aegis of Virginia, could only be legally obtained by extinguishing the Cherokee title. ${ }^{105}$

In reality, the Henderson Company had no legal standing in the western dynamic to extinguish title to land from either the Crown or Virginia.

Following the storyline three policy trends seem to emerge from the political milieu of the Royal Proclamation of 1763. Two of the trends had highly similar goals in that they both wanted the interior of North America opened to settlement. Between these two factions an ambiguous arrangement emerges as too who was involved with which camp. Between the two one policy goal sought to maintain the Crown's authority over new and existing North American colonies along with Indian affairs in the fashion of an imperial administration while the other 
policy construct was not concerned with the Crown's objectives except in the manner in which those goals interrupted local colonial ambitions. In 1767 an amended plan by the Board of Trade was considered that favored local colonial ambitions but was never officially adopted. That plan would have granted the control of Indian affairs over to the colonies while also dissolving the Indian Departments, ordering a military withdrawal of the frontier, establishing three new colonies in the Old Northwest, and opening the Mississippi River Valley to settlement. ${ }^{106}$

Instead, the 1768 plan was adopted; a plan that in many respects nullified the Royal Proclamation of 1763 and began a territorial expansion that, in theory, was under the exclusive control of the Crown. This plan left land purchases, the boundary line issue, and Indian affairs under the authority of the Indian departments wherein a military presence would be maintained at forts Niagara, Mackinac, and Detroit. ${ }^{107}$ The third policy construct sought to maintain an Amerindian interior though probably not for the reason of recognizing native authority for the Proclamation of 1763 measured Amerindian lands as falling under the sovereign authority of England; although it is not perfectly clear that this recognition of sovereign authority was to act as a counterweight to local colonial ambitions or to place Amerindian populations under the governance of the Crown or both. This policy trend attempted to secure a native interior to protect England's economic interests and to help maintain control over its own seaboard colonies while diverting future conflicts with tribal nations. On the other hand, following the success of Pontiac's War, the British began to modify their policy “...to acknowledge and accommodate native authority...”108 
Today, the Royal Proclamation is considered a dead letter in the canons of U.S. law and therefore has no bearing in the field of Federal Indian Law. In Canada the Royal Proclamation of 1763 survives and serves as a basis for indigenous land claims and other acknowledged rights. The Royal Proclamation is codified in Section 25 of the 1982 Canadian Constitution Act. It is also known as the "Indian Bill of Rights” or the "Indian Magna Carta”. 109

\section{Conclusions}

In the end, what the French and Indian War accomplished was a further deterioration of Trans-Appalachia borders in that there was no longer a French counter threat to English ambitions, and as events would reveal, more so the ambitions of the English colonies. Under the previous state of affairs where a bi-polar European authority existed at the edges of TransAppalachia perhaps Amerindian nationalism would have succeeded in the retention or formation of some sort of state(s) free of European subjugation and occupation. To clarify the position of Amerindians on the status of land, Sir William Johnson communicated to the Board of Trade and Plantations:

That it is a difficult matter to discover the true owner of any lands among the Indians is a gross error, which must arise from the ignorance of the matter or from a cause which does not require explanation. Each nation is perfectly well acquainted with its exact original bounds; the same is again divided into due proportions for each tribe and afterwards subdivided into shares to each family, with all which are most particularly acquainted. Neither do they ever infringe upon one another or invade their neighbour's hunting grounds. ${ }^{110}$

Regardless the French and Indian War induced a quickening pace for a rising nationalist movement in the thirteen colonies and also among the indigenous nations of the interior for upon conclusion of the war the British no longer sought unmitigated western expansion. Not until after the American Revolution would there exist again a bi-polar displacement of European authority 
between the early American Republic along the Atlantic seaboard and the English situated in Canada. But British Imperialism lacked the institutional coherency and consistency in decision making to follow through with its North American project or to maintain control of its own citizenry. When the English colonies began to identify less and less with their mother country and more and more with their own ambitions as British policy swayed one way then another on key issues such as territorial expansion the English lost control of their empire and for the most part would prove to be unreliable allies in the abiding contest that ensued in Trans-Appalachia. This seemingly left tribes with the choice of either engaging in intertribal confederation or reluctantly identifying with colonial power. Finally, the French and Indian War also did not explicitly determine the Spanish or French role in Trans-Appalachia either but it placed formidable restrictions upon them.

Needlessly to say, the grueling contest for Trans-Appalachia that began with such personally motivated measures from individuals like trader George Croghan operating in the Ohio River Valley during the 1740s. A trade operation like Croghan's fed the escalation between the French and English in their parlay for tribal allies and in this case led to the Conspiracy of 1747 in which tribal authorities attempted to eradicate all French trade and defense posts like Detroit or at least according to Croghan's personal notes. ${ }^{111}$ And ended with such events as the Creek Removal Wars that lasted well into the 1850s. In all these wars were about boundaries between societies whereas many if not all indigenous nations of Trans-Appalachia sought to maintain a separate existence. The Royal Proclamation has been addressed here because it was the first British government act to address the great border issue between tribal nations and 
colonial immigrants that in its design curtailed the practice of annexing indigenous land or in the least provided a western legal basis to protect indigenous land. In all, tribal polities were devastated, subdued, and otherwise left without the capacity to continue resistance. Today a common form of resistance to the denationalization of tribal nations is the retention of rights to self-determination and autonomy through federal or state recognition; albeit a thorny affair. 
${ }^{1}$ McCulley, Susan. (June 1987). Historic Jamestowne. http://www.nps.gov/jame/historyculture/baconsrebellion.htm. Retrieved January 2009.

${ }^{2}$ Yoho, James. (1999). "Interest Groups in America, 1498-1861." Dissertation at the University of Virginia. Ann Arbor, Michigan: UMI.

${ }^{3}$ Labaree, Leonard Woods. (1935). Royal Instructions to British Colonial Governors 1670-1776, Volume II. New York and London: D. Appleton-Century Company Incorporated.

${ }^{4}$ The Avalon Project. (2008). The Third Charter of Virginia; March 12, 1611. Yale Law Library. http://avalon.law.yale.edu/17_century/va03.asp. Retrieved July 2009.

${ }^{5}$ Yoho, James. (1999).

${ }^{6}$ Labaree, Leonard Woods. (1935).

${ }^{7}$ Reported in Kupperman, Karen Ordahl, editor. (1993). Major Problems in American History Documents and Essays. Lexington, Massachusetts: D.C. Heath and Company. Page 232.

${ }^{8}$ Jennings, Francis. (1975). The Invasion of America Indians, Colonialism, and the Cant of Conquest. Chapel Hill: The University of North Carolina Press.

${ }^{9}$ Yoho, James. (1999).

${ }^{10}$ Labaree, Leonard Woods. (1935).

${ }^{11}$ Abernathy, Thomas Perkins. (1937). Western Lands and the American Revolution. New York and London: D. Appleton-Century Company Incorporated.

${ }^{12}$ Sato, Shosuke; Special Commissioner of the Colonial Department of Japan. (1886). "History of the Land Question in the United States." John Hopkins University Studies in Historical and Political Science, Fourth Series VII-VIIIIX. Herbert B. Adams, Editor. Baltimore, Maryland: N. Murray, Publication Agent and Isaac Friedenwald, Printer.

${ }^{13}$ Yoho, James. (1999). Pages 54-55.

${ }^{14}$ Young, R.J. (2001). Postcolonialism: An Historical Introduction. Malden, Massachusetts: Blackwell Publishers.

${ }^{15}$ Moore, Charles. (1900). The Northwest Under Three Flags 1635-1796. New York and London: Harper and Brothers Publishers.

${ }^{16}$ Baar, Daniel P. (2001). “Contested Land: Competition and Conflict Along the Upper Ohio Frontier, 1744-1784.” Dissertation at Kent State University: Ann Arbor, Michigan USA:UMI.

${ }^{17}$ Baar, Daniel P. (2001). Page 200.

${ }^{18}$ Carter, Clarence E. (Jan 1911). "Document Relating to the Mississippi Land Company, 1763-1769." The American Historical Review, Vol 16 No 2 pp 311-319.

${ }^{19}$ Carter, Clarence E. (Jan 1911). 
${ }^{20}$ Moore, Charles. (1900).

${ }^{21}$ Moore, Charles. (1900).

${ }^{22}$ Carter, Clarence E. (Jan 1911).

${ }^{23}$ Graves, William Hilton. (1982). "The Evolution of American Indian Policy." Dissertation at Florida State University. Ann Arbor, Michigan: UMI.

${ }^{24}$ Eliades, D. K. (1981). "The Indian Policy of South Carolina 1670-1763." Dissertation at the University of South Carolina . Ann Arbor, Michigan, USA: UMI.

25 Stuart, John. "John Stuart to the...” Virginia State Papers, Papers of the Continental Congress, Volume II. Washington, D.C: The National Archive. M247 R85. Page 218.

${ }^{26}$ Hagy, J.W. and S.J. Folmsbee. (1972). The Lost Archives of the Cherokee Nation (Part 1, 1763-1772). The East Tennessee Historical Society's Publications, No 44 pp 114-125.

${ }^{27}$ Labaree, Leonard Woods. (1935). Page 467.

${ }^{28}$ Labaree, Leonard Woods. (1935). Page 477.

${ }^{29}$ Hagy, J.W. and S.J. Folmsbee. (1972).

${ }^{30}$ Braund, K. E. (1986). "Mutual Convenience--Mutual Defense: the Creeks, Augusta, and the Deerskin Trade 17331783." Dissertation at Florida State University. Ann Arbor, Michigan, USA: UMI.

${ }^{31}$ Haan, R. L. (2003). Covenant and Consensus Iroquois and English 1676-1760. In Beyond the Covenant Chain, The Iroquois and Their Neighbhors in Indian North America 1600-1800. Daniel Richter and James Merrell, Editors. University Park, Pennsylvania: The Pennsylvania State University Press.

${ }^{32}$ Stevens, W. E. (Sep 1916). The Organization of the British Fur Trade 1760-1800. The Mississppi Valley Historical Review, Vol 3 No 2 pp 172-202.

${ }^{33}$ Stevens, W. E. (Sep 1916).

${ }^{34}$ Young, R.J. (2001).

${ }^{35}$ Stevens, W. E. (Sep 1916).

${ }^{36}$ Stevens, W. E. (Sep 1916).

${ }^{37}$ Yoho, James. (1999).

${ }^{38}$ Young, R.J. (2001).

${ }^{39}$ Reported in Humphreys, R. (Apr 1934). Lord Shelburne and the Royal Proclamation of 1763. The English Historical Review, Vol 49 No 194 pp 241-264. Page 246. 
${ }^{40}$ Humphreys, R. (Apr 1934).

${ }^{41}$ Reported in Humphreys, R. (Apr 1934). Page 247 \& 248.

${ }^{42}$ Humphreys, R. (Apr 1934).

${ }^{43}$ Humphreys, R. (Apr 1934).

${ }^{44}$ Carter, C. E. (1918). British Policy Toward American Indians in the South 1763-1768. The English Historical Review, Vol 33 No 129 pp. 37-56.

${ }^{45}$ Labaree, Leonard Woods. (1935).

${ }^{46}$ Humphreys, R. (Apr 1934).

${ }^{47}$ Baar, Daniel P. (2001).

${ }^{48}$ Humphreys, R. (Apr 1934).

${ }^{49}$ Abernathy, Thomas Perkins. (1937). Page 11.

${ }^{50}$ Humphreys, R. (Apr 1934).

${ }^{51}$ Larrabee, Edward McM. (1976). "Recurrent Themes and Sequences in North American Indian-European Culture Contact.” Transactions of the American Philosophical Society. Vol 66 No 7 pp 1-52.

${ }^{52}$ Hatheway, G. (1957). “The Neutral Indian Barrier State a Project in British North American Policy 1754-1815.” Dissertation at the University of Minnesota . Ann Arbor, Michigan, USA: UMI.

${ }^{53}$ Lancaster Treaty of 1744. (2009).

http://cc.msnscache.com/cache.aspx?q=treaty+of+lancaster\&d=75625919239725\&mkt=en-US\&setlang=enUS\&w=8bc6a691,c1931f71. Retrieved July 2009.

${ }^{54}$ Baar, Daniel P. (2001).

${ }^{55}$ Goltz, J. H. (1973). “Tecumseh, The Prophet, and the Rise of the Northwest Indian Confederation.” Dissertation at the University of Western Ontario. London, Canada.

${ }^{56}$ Moore, Charles. (1900).

${ }^{57}$ Baar, Daniel P. (2001). Page 201.

${ }^{58}$ Sheidley, N. J. (1999). "Unruly Men: Indians, Settlers, and the Ethos of Frontier Patriarchy in the Upper Tennessee Wateshed 1763-1815". Dissertation at Princeton University. Ann Arbor, Michigan: USA.

${ }^{59}$ Quoted in Baar, Daniel P. (2001). Page 199. 
Brief summary available in Quaife, Milo M. (1915). The Preston and Virginia Papers of the Draper Collection of Manuscripts, Vol 1. Madison, Wisconsin. State Historical Society of Wisconsin. Page 56.

${ }^{60}$ Yoho, James. (1999).

${ }^{61}$ Baar, Daniel P. (2001).

${ }^{62}$ Yoho, James. (1999).

${ }^{63}$ Hatheway, G. (1957).

${ }^{64}$ Humphreys, R. (Apr 1934).

${ }^{65}$ Hatheway, G. (1957).

${ }^{66}$ Hatheway, G. (1957). Page 200.

${ }^{67}$ Abernathy, Thomas Perkins. (1937).

${ }^{68}$ Humphreys, R. (Apr 1934).

${ }^{69}$ Abernathy, Thomas Perkins. (1937).

${ }^{70}$ Hatheway, G. (1957).

${ }^{71}$ Stevens, W. E. (Sep 1916).

${ }^{72}$ Hatheway, G. (1957).

${ }^{73}$ Carter, C. E. (1918).

${ }^{74}$ Humphreys, R. (Apr 1934).

75 Moore, Charles. (1900).

${ }^{76}$ Baar, Daniel P. (2001).

${ }^{77}$ Humphreys, R. (Apr 1934).

${ }^{78}$ Sato, Shosuke; Special Commissioner of the Colonial Department of Japan. (1886).

${ }^{79}$ Hatheway, G. (1957).

${ }^{80}$ Sato, Shosuke; Special Commissioner of the Colonial Department of Japan. (1886).

${ }^{81}$ Moore, Charles. (1900). 
${ }^{82}$ Labaree, Leonard Woods. (1935).

${ }^{83}$ Moore, Charles. (1900).

${ }^{84}$ Walker, M. G. (Dec 1916). Sir John Johnson. The Mississippi Valley Historical Review, Vol 3 No 3 pp 318-346.

${ }^{85}$ Moore, Charles. (1900).

${ }^{86}$ Moore, Charles. (1900).

${ }^{87}$ Hagy, J.W. and S.J. Folmsbee. (1972).

${ }^{88}$ Baar, Daniel P. (2001).

${ }^{89}$ Fierst, J. T. (2000). "The Struggle to Defend Indian Authority in the Ohio Valley-Great Lakes Region 17631794." Dissertation at the University of Manitoba (Canada) . Ann Arbor, Michigan, USA: UMI.

${ }^{90}$ Baar, Daniel P. (2001).

${ }^{91}$ Fierst, J. T. (2000).

${ }^{92}$ Hagy, J.W. and S.J. Folmsbee. (1972).

${ }^{93}$ Moore, Charles. (1900).

${ }^{94}$ Hagy, J.W. and S.J. Folmsbee. (1972).

${ }^{95}$ Baar, Daniel P. (2001).

${ }^{96}$ Hagy, J.W. and S.J. Folmsbee. (1972).

${ }^{97}$ Marshall, Peter. (1965). “Lord Hillsborough, Samuel Wharton and the Ohio Grant 1769-1775.” The English Historical Review. Vol 80 No 3 pp 717-739.

${ }^{98}$ Yoho, James. (1999).

${ }^{99}$ Baar, Daniel P. (2001).

${ }^{100}$ Sato, Shosuke; Special Commissioner of the Colonial Department of Japan. (1886).

${ }^{101}$ Dillon, J. B. (1879). Oddities of Colonial Legislation in America, as Applied to the Public Lands, Primitive Education, Religion, Morals, Indians, Etc., Etc., with Authentic Records... with a Summary of the Territorial Expansion, Civil Progress and the Development of the Nation. Indianapolis, Indiania: Robert Douglas, PublisherElectrotyped at the Indianapolis Electrotype Foundry, Ketcham and Wanamaker, Proprietors.

${ }^{102}$ Macfarlane, P. (1999). “Two French Threats to North America 1760-1783 as seen by British Colonial Officials.” Dissertation at Concordia University, Montreal, Quebec, Canada. 
${ }^{103}$ Innis, Harold A. The Fur Trade In Canada. New Haven, Connecticut: Yale University Press. 1930.

${ }^{104}$ Henderson, A. (Oct 1914). The Creative Forces in Westward Expansion: Henderson and Boone. The American Historical Review, Vol 20 No 1 pp 86-107.

${ }^{105}$ Henderson, A. (Oct 1914). Page 105.

${ }^{106}$ Graves, William Hilton. (1982).

${ }^{107}$ Graves, William Hilton. (1982).

${ }^{108}$ Fierst, J. T. (2000). Page 100.

${ }^{109}$ Hall, A. J. (2008). Royal Proclamation of 1763. The Canadian Encyclopedia HISTORICA:http://www.thecanadianencyclopedia.com/index.cfm?PgNm=TCE\&Params=A1ARTA0006990. Retrieved April 2008.

${ }^{110}$ Reported in Mershon, S.L. (1918). English Crown Grants the Foundation of Colonial Land Titles Under English Common Law. New York, New York: The Law and History Club Publishers 39 Cortlandt Street. Page 91.

${ }^{111}$ Wainwright, Nicholas B. George Croghan and the Indian Uprising of 1747. Lancaster, Pennsylvania: Presentation at the annual meeting of the Pennsylvania Historical Association: October 24, 1953. 


\section{Section II Historical Briefs}

\section{Chapter 4-The Ohio Frontier}

On October 31, 1753 Major George Washington, commissioned by the provincial government of colonial Virginia for militia service, journeyed to the French Fort Le Boeuf in the Ohio country on behalf of Lieutenant Governor Dinwiddie to demand the complete withdrawal of French troops. ${ }^{1}$ Significantly, Major Washington and the provincial government of Virginia acting under the authority of its sea-to-sea charter to acquire new lands, was taking the first steps into the French and Indian War, a war that would essentially hasten the impetus for settlement of the Trans-Appalachia interior. In his even earlier days, George Washington was a land surveyor employed by Virginia land owner Lord Fairfax. ${ }^{2}$ Although the French Crown would continue to involve itself in the affairs of North America even with a future plot to reestablish New France during the American Revolution, this war was the critical factor to ending its imperial ambitions in North America.

Eleven weeks later in the winter of 1754, Major Washington returned and advised the Virginia Council to erect a fort at the Forks of the Ohio River, where the Monongahela and Allegheny rivers join to form the Ohio River. From there, Washington maintained that the Ohio River Valley could be controlled in its entirety. That same winter the Virginia council conspired to eject the French from the Ohio country with the creation of a militia regiment consisting of six companies; units were dispatched to build Fort Prince George (Pittsburgh). By mid-spring a Franco-Amerindian force captured the fort and renamed it Fort Duquesne. ${ }^{3}$ 
While Major Washington was carrying out the Virginia Council’s and Ohio Company’s territorial expansion program in the interior of North America, the English and French Crowns had been, since 1750, attempting to negotiate, in Paris, a suitable North American boundary to distinguish their distinct territorial dispositions. The English pursued their objectives through previous agreements established by the treaties of Utrecht and Aix-la-Chapelle. They also relied on the dubious right of discovery in conjunction with the charters of their respective colonies. ${ }^{4}$ The English further augmented their claims through their standing alliance with the Iroquois and additional claims that regarded certain tribal populations of the interior as rightfully subjects to the English Crown. At one point in the negotiations a French official stated, "The Indians in question are free and independent, and none of them can be termed subjects of either crown.” 5 By 1755 the negotiations entered a stage wherein the proposed stipulations included the removal of British and French forces from:

...the Countries upon the Ohio, and a total Demolition of all Forts and Settlements in those Parts: so that the said Country, from the Back of His Majesty's Colonies to the Lakes, and as far as the River Oubash, may be left in the same state as It was by the Treaty of Utrecht. ${ }^{6}$

Subsequently the proposal called for this vast area to be considered a neutral country for the exclusive possession by tribal nations where the respective European powers could participate in free trade and enjoy open passage for trade reasons on primary waterways such as the Great Lakes and other navigable rivers. In addition the final proposal called for the cancellation of all land grants into the region. However, the compact was never entered into as neither France nor England could compromise over certain strategic locations such as Fort Duquesne at the Forks of the Ohio. ${ }^{7}$ 
The Ohio River eventually merges with the Mississippi River thus granting trade advantages to whoever controlled it. These negotiations should not be mistaken as a European acknowledgement of sovereign tribal rights just for the sake of acknowledging such rights; rather these rights were considered by the manner in which they also served European interests for at one point in the negotiations, "France, like England, insisted on leaving the tribes between Canada and Louisiana neutral and independent, to serve as a barrier [state].”8 In this respect the tribal nations would remain available for future alliance seeking and security designs rather than risking a diplomatic failure by forcing the issue. During these negotiations the Crown of England ordered the colonial governors to prepare for a defense against a French invasion, but were also instructed not to engage in any acts of aggression themselves. ${ }^{9}$

Generally speaking, European authorities acknowledged Amerindian status in the context of their own quarrels and how that status could be manipulated to reflect upon inter-European issues, but Amerindian status was also recognized in the context of internal European politics. Often Amerindian status was only recognized with advantageous prejudice when Amerindian polities affected positive outcomes for themselves from successful martial adventures. Other contexts in which Amerindian status held sway with European authorities occurred in trade and security issues in which colonies were dependent upon their Amerindian allies. The nature of European acknowledgement of Amerindian status has a very provisional feature to it, but less so with Franco-Amerindian relations.

Fort Duquesne at the Forks of the Ohio was not the only contested strategic ground among the French and English, but was also contested between the colonies of Pennsylvania and 
Virginia as understood in the design of their independent and separate colonial charters. ${ }^{10}$ By the virtue of the colonial charters a divide occurred between British Imperial policy and the goals of British colonial provinces in North America. While the colonial charters themselves were a creation of British Imperial Policy, their existence became the institution that would no longer respond in accordance to His Majesty’s directives and simultaneously became the device from which colonial rebellion would develop. Here the local ambitions of colonies undermined the Crown's ability to exercise its authority unilaterally. Not until May of 1756 would England and France formally declare war on one another. Nonetheless, the actual war, as noted before, had begun years earlier in a manner that reflected local actors involved with the fur trade and land. Both France and England had made an attempt to avoid renewed warfare, but without success. Accordingly, the French would ally themselves with primarily Algonquian tribal nations while the English primarily allied with Iroquoian peoples such as the Six Nations and the Cherokee. ${ }^{11}$

By 1750, Christopher Gist was commissioned by the Ohio Company to survey lands along the Ohio River. ${ }^{12}$ Gist travelled as far as the Great Falls of the Ohio River, modern day Cincinnati, while operating covertly. He never revealed the purpose of his travels to tribal authorities. The company’s structure was organized to act in multiple capacities that included military, population settlement, and trade roles; its charter required it to construct forts and provide for settlement of 200 individuals before proceeding with any further developments. As early as the summer of 1752, company representatives had negotiated an agreement with local tribal authorities to construct a fort. However, the tribal authorities did not consent to any land cessions or settlements. During this time the French and their tribal allies countered the 
Virginians’ presence into the Ohio Country by attacking Miami villages hosting British traders. ${ }^{13}$ Forts acted as regional trade, diplomatic and communication centers and were therefore valued by both tribal and European authorities.

In due course, land acquisition and territorial expansion emerge as the germane issue, even at this early time for the English colonies and it would become a definitive and substantive feature of the thirteen colonies’ movement towards a nationalist state. The Loyal Company commissioned Joseph Martin to investigate as far west and south as the Cumberland Gap where he was to begin his land survey after erecting a company station for future operations. The Loyal Company's land grant was centered in the proximity of the Virginia-Carolina border and boasted a roster of recognizable figures such as Edmund Pendleton. ${ }^{14}$ Other prominent members included Peter Jefferson, father of Thomas Jefferson, and Thomas Meriwether, the grandfather of Meriwether Lewis. ${ }^{15}$ The story of American nationalism unfolds as a mad self-serving scramble for land despite the initial and probable long term consequences. In the 1750s, Jacob Martin and others established themselves on the waterways of what is now West Virginia. By 1764, these settlements ceased to exist due to the action of tribal authorities who kept settlers out of the region until 1769. Families risked severe outcomes when they did not heed to orders from their own government to remove themselves from tribal lands. ${ }^{16}$

Japanese scholar, Shosuke Sato suggested, "Perhaps slavery and the public domain are the two most important factors in the politico-economic history of the United States."17 He points out that public lands were used as bounties to veterans stretching from the Revolution to the Civil War, provided a basis for national finance and public revenue, and often held center stage 
in national diplomacy through the purchase of territories. Boundary negotiations were highlighted by the involvement of statesmen ranging from Pinckney, Livingston, and Monroe. Additionally, the administration and survey of public lands were begun by Jefferson as a committee chairman in Congress in 1784, and by Secretary of Treasury Alexander Hamilton in 1790. ${ }^{18}$ Hamilton proposed the selling of western lands to pay off the government's debt obligations to European nations. ${ }^{19}$ Public land grants have been the method by which to improve the public infrastructure through canals, levees, highways, and railroads while also providing the means to promote public education via state universities or other public schools. Public land grants created mechanical and agricultural institutions. Public land grants also provided for the development of mineral resources creating benefits for the general economy. ${ }^{\mathrm{A}}$ Slavery served a similar purpose. Christopher Columbus, in part, used indigenous American slaves that were sold in European and African markets to finance his voyages. The American export slavery market was also a manner that provided revenue to develop the British colonies. ${ }^{20}$ Sato concluded: Lastly, the relation of public lands to immigration suggests an important economic problem. 'No State without people' should be the political maxim of statesman in encouraging foreign immigration. Free homes and free institutions, free labor and free soil, are the best capital for the development of the resources of the Great West ... Such is the scope of the land question in the

\footnotetext{
${ }^{A}$ The subject matter of land and slavery also provides a basis to understand identity standards that developed during the Colonial era. Forbes (1993, Page 5) points out that indigenous people of the Americas were arbitrarily assigned to racial categories in conjunction with the emergence of Colonial era social ranks or castes. Indigenous Americans often were inappropriately misidentified as black or African by government institutions and "powerful outsiders." Forbes considers these events as racist and hopes that research into this topic will aid in the development of human rights. Counterpoise, indigenous Americans also manipulated government institutions at the risk of convoluting outsider perceptions of their identity. Scholar Foster (2003) reports on the involvement of ethnic Cherokee in the territorial courts of Arkansas in the early 1800s. One Cherokee individual known as Connitue also known by his Anglo name John Hill had served on two juries, a right reserved to white males. One case involved assault and battery charges while the other case involved robbery allegations. But John Hill or Connitue was no longer able to serve in the jury system when a civil case brought against him was dismissed as he claimed the court held no jurisdiction over him as he was a Cherokee. The court happened to agree.
} 
general economy of the United States. In this and all other questions, the public interest is deeply concerned with the administration and disposition of the public domain. Notwithstanding the rapid disposition of the public lands, there yet remain scattered all over the southern, the western, and the Pacific regions, vast tracts of unoccupied lands, the aggregate area which is almost twice the as great as that of the national domain in 1783. Tides of immigration still flow from across the ocean. Millions of homes can be created. An immense wealth and vast resources can be developed. Towns will multiply; counties will grow; free institutions will spring into life. This material advance and prosperity will be due to the public domain and its judicious disposition. ${ }^{21}$

Such is the critical scope of American nationalism. The evidence presented by the role of land in the affairs of those who created the American state confounds other explanations to the national unification of the thirteen colonies and their concurrent rebellion against their mother country England. Some scholars have acknowledged the ancillary role of "some powerful democratic tendencies” while regarding the Revolution as primarily an "elitist movement” in which the role of "western expansion” necessitates further investigation ${ }^{22}$. Other scholars have also maintained that the fundamental character of the revolutionary nationalist was territorial expansion. $^{23}$

Consider for a moment at what point did Amerindian nations or European kingdoms become a threat to the liberty and livelihood of the English colonies? Amerindian nations and European kingdoms became threats only at the intersection of continual westward expansion. From the paradigm of American nationalism would arise three government directives of U.S. foreign policy to navigate these contrived threats. The first being the Northwest Ordinance, the second, Federal Indian Policy and the third, the Monroe Doctrine that transformed a series of land company projects into a nationalist movement. The original architects of Federal Indian Policy were none other than President George Washington and the Secretary of War Henry Knox. ${ }^{24}$ From the institution of Federal Indian Policy within the framework of American 
nationalism centered in an ethic of territorial expansion, then this policy (or this institution) can be branded with the goals of defeating, controlling, and eventually reinventing Amerindian nationalism. Meanwhile, the Monroe Doctrine preempted any further European intrusion into the affairs of the American Republic or with the Amerindian nations within its claimed jurisdiction. The Northwest Ordinance established the first U.S. territory in the Trans-Appalachia region.

Events accelerated rather quickly in the Old Northwest. The Ohio Company failed to secure the Forks of the Ohio, and Major Washington's plans to recapture Ft. Duquesne, with the help of a thousand Cherokee and Catawba warriors, never materialized. ${ }^{25}$ From Fort Necessity in Great Meadows, Pennsylvania, Major Washington began offensive operations by attacking a unit of French regulars. Major Washington would continue with an unsuccessful attack on Fort Duquesne. By mid-summer, a Franco-Amerindian force numbering over a thousand warriors forced Washington to surrender Fort Necessity. Washington unknowingly confessed to the murder of a French officer when he signed the papers of capitulation. Later on in the year 1754, Major Washington resigned his Virginia militia position, and without success requested a commission into His Majesty’s British Army. Subsequently in the summer of 1755, Washington would gain a new commission with the rank of colonel in Virginia's reformed militia regiment, all this at the age of twenty-three. ${ }^{26}$

All told, framing American nationalism in the necessary terms of land abrogation, it is a mistake to consider the actions of George Washington, the Land Companies’ and the colonial legislatures as a reflection of British Imperialism because it necessitates a diverging point where British Imperialism and the British colonies of North America no longer saw eye-to-eye in the 
provisions of their North American affair. By 1761 the authority to procure Amerindian lands was exclusively returned to the authority of the British Crown and removed from the colonies. ${ }^{27}$ In subsequent years the American rebellion was the result of diverging interests over territorial expansion and, at first, the European relationship to the Amerindian nations inhabiting that land. 
${ }^{1}$ Bluhm, J. C. (2004). U.S. Army a Complete History. Arlington, Virginia: Hugh Lauter Levin Associates, Inc.

${ }^{2}$ Hamilton, Peter J. Colonial Mobile. USA: University of Alabama Press. 1976.

${ }^{3}$ Bluhm, J. C. (2004).

${ }^{4}$ Hatheway, G.G. (1957). "The Neutral Indian Barrier State a Project in British North American Policy 1754-1815." Dissertation at the University of Minnesota. Ann Arbor, Michigan: UMI.

${ }^{5}$ Pease, Theodore Calvin, ed. (1936). Anglo-French Boundary Disputes in the West 1749-1763. French Series, Vol II: Collections of the Illinois Historical Library, Vol XXVII. Springfield, Illinois: Trustee of the Illinois State Historical Library. Page 223.

${ }^{6}$ Reported in Hatheway, G.G. (1957). Page 92.

${ }^{7}$ Hatheway, G.G. (1957).

${ }^{8}$ Pease, Theodore Calvin, ed. (1936). Page cxvi.

${ }^{9}$ Beer, George Louis. (1933). British Colonial Policy 1754-1765. New York: Peter Smith. (Reprinted by Special Arrangement with the MacMillan Company: 1907)

${ }^{10}$ Hatheway, G.G. (1957).

${ }^{11}$ Graves, William Hilton. (1982). "The Evolution of American Indian Policy." Dissertation at Florida State University. Ann Arbor, Michigan: UMI.

${ }^{12}$ Camenzind, K. (2002). "From the Holy Experiment to the Paxton Boys: Violence, Manhood, and Race in Pennsylvania during the Seven Years War.” Dissertation at the University of California, San Diego. Ann Arbor, Michigan, USA: UMI.

${ }^{13}$ Hatheway, G.G. (1957).

${ }^{14}$ Egnal, M. (1980). The Origins of the Revolution in Virginia: A Reinterpretation. The William and Mary Quarterly, 3rd Ser. Vol 37 No 3 pp. 401-428.

${ }^{15}$ Lewis \& Clark. 16. Loyal Company Grant. July 12, 1749. 2007. University of Virginia Library. http://www.lib.virginia.edu/small/exhibits/lewis_clark/exploring/ch3-16.html. Retrieved April 2007.

${ }^{16}$ Moore, Charles. The Northwest Under Three Flags 1635-1796. New York and London: Harper and Brothers Publishers, 1900.

${ }^{17}$ Sato, Shosuke; Special Commissioner of the Colonial Department of Japan. "History of the Land Question in the United States." John Hopkins University Studies in Historical and Political Science, Fourth Series VII-VIII-IX.

Herbert B. Adams, Editor. Baltimore, Maryland: N. Murray, Publication Agent and Isaac Friedenwald, Printer., 1886. Page 264.

${ }^{18}$ Sato, Shosuke; Special Commissioner of the Colonial Department of Japan. 1886. 
${ }^{19}$ Alexander Hamilton and Finance in the Washington Administration. Sparknotes. 2010. http://www.sparknotes.com/history/american/statebuilding/section9.rhtml. Retrieved February 2010.

${ }^{20}$ Forbes, Jack. (1993). Africans and Native Americans The Language of Race and the Evolution of Red-Black Peoples, 2nd Edition. Urbana and Chicago: University of Illinois Press.

${ }^{21}$ Sato, Shosuke; Special Commissioner of the Colonial Department of Japan. 1886. Pages 265 \& 279.

${ }^{22}$ Greene, J. P. (1968). The Reinterpretation of the American Revolution 1763-1789. New York, New York: Harper and Row, Publishers. Pages 36 \& 53.

${ }^{23}$ Egnal, M. (1980).

${ }^{24}$ Graves, William Hilton. (1982).

${ }^{25}$ Hatheway, G.G. (1957).

${ }^{26}$ Bluhm, J. C. (2004).

${ }^{27}$ Carter, C. E. (1918). British Policy Toward American Indians in the South 1763-1768. The English Historical Review, Vol 33 No 129 pp. 37-56. 


\section{Chapter 5-Six Nations a Frontier Broker}

In 1754 Half-KingTenachrissan, leader and acting authority for the Iroquois League in Ohio, murdered Jumonville, a French soldier, after Washington's attack on a French unit. He proceeded to communicate to French officials of a British directed slaughter in an attempt to motivate the French toward open warfare with the British. ${ }^{1}$ Tenachrissan, or the Seneca HalfKing, habitually offered resistance to a French presence in the Ohio country and was now trying to also resist English authority. In prior months, Tenachrissan had informed French Commander Pierre Paul Marin that the region belonged to the Six Nations, upon which Marin informed Tenachrissan that the region rested under the authority of the French. ${ }^{2}$ The Seneca Half-King conspired to weaken both European authorities through initiating a conflict between the two. Here, the Six Nations would also be able to re-establish a persuasive authority over the Ohio tribal nations. ${ }^{3}$ Such extra political measures taken by Six Nations’ representatives, at a time when the Iroquois League was bound to an agreement of neutrality in conflicts between the two Crowns, is reminiscent of the politics pursued by the Huron leader The Rat decades earlier. The Rat's political endeavors resulted in the Six Nations agreement to neutrality.

The Iroquois League, or the Six Nations, officially maintained a non-alignment posture as late as 1759, although they were heavily invested in the campaigns during the early years of the war. Six Nations leaders accompanied English and French military forces in Ohio Valley and Canadian campaigns in an attempt to maintain their non-alignment posture, but eventually these escort commitments turned into combat commitments. These martial entanglements placed the 
Six Nations at odds with other Iroquois populations. During the 1660s some Iroquois immigrated to Montreal and would later be distinguished in a separate entity as part of the Seven Nations of Canada who often aligned themselves with the French. The Six Nations may have attempted to deploy an elaborate strategy to keep both the French and English dependent upon League status as a diplomatic intermediary and buffer. ${ }^{4}$ In this respect the League’s access to both the Montreal and Albany fur trade would have been secured. Past events and conflicts suggest the League was divided over its inclinations to act multi-laterally with the French. However, the League in its entirety was obligated to some degree to act in a multi-lateral fashion with the English, as the Six Nations was the pivotal Amerindian nation in the Covenant Chain regime.

This sort of free rider strategy carried significant risks to the national interest of the Six Nations, for by its nature it eventually alienated both the English and French, not to mention the client native states the Iroquois were presumably providing for. This was a free rider strategy in that the League relied on the commitment of resources by other actors than itself to achieve its goals. Their strategy, if successful, would have left the English, French, and other tribal nations more dependent on the backing of the Six Nations. Further, it appealingly assumed that, as in previous colonial conflicts, there would be no clear victor between the English and the French, thus preserving the status quo of Six Nations ascendency. Ultimately in the French and Indian War, the Six Nations Confederacy would begin to unravel as it would ultimately commit its own resources into the war. Eventually the Mohawk actually fought alongside the English while the 
Seneca participated in joint war parties against the Crown. ${ }^{5}$ At the Battle of Lake George both League Seneca and League Mohawk would fight on opposite sides.

Furthermore, the Iroquois claim to holding authority over the Shawnee and Delaware, a position that allowed them to grasp more influence with colonial authorities, also began to come under strain. Nonetheless the Iroquois would continue well into the future to exploit this claim while bargaining with colonial authorities at the expense of other tribal nations. Herein again, the resources of others were manipulated to achieve League goals without ever committing a significant resource of their own, a free rider method of negotiating wherein the League was able to manipulate the stakes and goals of other parties to advance its own security. This was achieved by a purported claim of regional authority that did not necessarily represent the actual political demographics of the region.

During the winter of 1755 the Susquehanna Valley Nations, consisting primarily of Delaware and Shawnee, rejected the governing Onondaga Council of the Six Nations and began raiding settlements. The Shawnee and Delaware began breaking formal ties with the League by kidnapping one of their own representatives in the League council and threatening the lives of others on that council. Formal ties to the League were further extinguished when the Delaware sachem Teedyuscung began cooperating with the English colonies directly to form a peace; he did so without regard for the Onondaga Council. Despite his efforts, the Munsee Delaware would continue to war against the English. Consequently, many Shawnee and Delaware of the Susquehanna Valley, living under the indistinct sphere of Six Nations authority, would depart to the Ohio River Valley. ${ }^{6}$ 
In 1756, French General Marquis de Montcalm, captured Fort Oswego, the only British post of significance on the Great Lakes. From this point on, the Mohawks alone of the Six Nations would retain an allegiance with the English or at least to Sir William Johnson, future Superintendant to the Northern Indian Department. ${ }^{7}$ Closer scrutiny uncovers a Mohawk tradition of operating independently at times in reflection of their own commitment to the Iroquois League Council, or rather they may have considered their nation proprietors to the League Council, thus granting them more freedom in diplomatic action. To understand the Six Nations national interest, and equally, to understand the dynamics of nationalism in TransAppalachia, the Covenant Chain must be examined. The likely origins of the Silver Chain or the Covenant Chain date back to the 1670s when New York Governor Edmund Andros solicited the Mohawk and the then Five Nations Iroquois League to assist in the New England campaign against Metacom of the Wampanoag. The Wampanoag were a threat to the territorial expansion of New England. By 1677 the Iroquois League was invited to Albany by officials of Maryland to converse further over the war raging about the Chesapeake provinces. Arguably, the Onondaga leader Garakontie, through the process of these meetings, established the initial terms of a Silver Covenant Chain. ${ }^{8}$

Metacom's War is significant in that 11,000 native people participated in the conflict with thousands of natives and colonists losing their lives. Starvation and disease were devastating to Metacom's efforts. As the war turned for the worse, the English hunted down the various remaining defenders, executing some, and selling others into slavery for service in the West Indies. The Abenaki, along with others, migrated to St. Francis in Quebec, which provided 
shelter to the refugee peoples of Metacom’s War. Other peoples took sanctuary in a Mahican community provided by Governor Andros in New York. Still others would flee elsewhere, while some would stay and endure. ${ }^{9}$ The Six Nations responded to the colonial call for aid, and an exclusive party of Mohawk engaged Metacom’s forces in 1676. By the 1680s the coordinated efforts of New York Governor Thomas Dongan and Lord Howard of Effingham of Virginia expanded upon the institution of the Covenant Chain with the then Five Nations through an arrangement that expanded the Albany trade further west, prescribed divisions of control over the native peoples on the borders of Virginia, and elaborated on sovereign English claims to North American territories. $^{10}$

The Six Nations found in the English an opportunity to thwart French designs against them. In 1665 the French sent the Carignan-Sallieres Regiment to New France in which they executed a devastating campaign against the Five Nations so that New France could institute regional control of the fur trade. By 1690 the Iroquois League, as cohort to the English, began campaigns against the Saint Lawrence River Valley and Quebec City. By 1693, French regulars, accompanied by Mission Iroquois and militia, had defeated the League Mohawk. Richter suggests that by the turn of the century, the Iroquois League faced the possibility of extinction from continual war. ${ }^{11}$ In 1701 the League of Iroquois were obligated to sign a treaty whereby they declared their neutrality between the European Kingdoms of France and England. ${ }^{12}$ That summer, the League signed two treaties: one in Montreal with New France, and one in Albany with New England. From then on, the Five Nations would continue in a relationship of duplicity with the English, French, and tribal nations as would English and French authorities who sought 
to maintain Iroquois non-alignment with economic and political concessions. Rarely would France or England exercise the obligations of an exclusive alliance with the League. ${ }^{13}$ From here perhaps the League developed their non-alignment and free rider strategies. ${ }^{\mathrm{A}}$ The League from then on would hesitate to side with any one European power against another European authority. The Rationale expressed by an Onondaga leader to Governor Robert Hunter in 1711:

...we are not like you Christians for when you have taken Prisoners of one another you send them home, by such means you can never route one another. We are not of that nature, when we have war against any nations we endeavor to destroy them utterly. ${ }^{14}$

The Covenant Chain, over its duration, is questionably proposed to best have served the interest of British Imperialism; nevertheless, it served the League interest also. For example, during the French and Indian War, the Crown ordered both Virginia and New York to not issue any land grants into League territory, but to aid the League in maintaining the integrity of their territory. Its general structure tied New York and other colonies of New England to the League and its tribal adherents. ${ }^{15}$ More so, the Covenant Chain required certain commitments upon its participants. On the part of the colonies, it required them to acknowledge the leadership of the League in the affairs of other tribal nations, which the colonies were happy to indulge, for it often aided them in extinguishing Amerindian claims to lands.

In the 1710s, the League’s influence grew as Nanticoke, Conoy, Shawnee, and Delaware (to name a few) began migrating to the Susquehanna Valley where they would settle under the increasing southern sphere of Iroquois influence. Here in the Susquehanna Valley, tribal nations

\footnotetext{
${ }^{\text {A }}$ Prior to 1701 The League actively pursued the expansion of its control of the fur trade through the direct conquest of other tribes. In this respect, The League could maintain its position as a trade broker between other tribes and the merchants of Albany with the additional goal of placing restrictions on the Montreal trade network.
} 
lived under the authority and protection of the League. In the League's southern expeditions they suppressed the Yamasee nation on behalf of requests from officials in New York and South Carolina who had been warring with the Yamasee. Furthermore, the League absorbed the southern Tuscarawa Nation who were being devastated by slavers, new settlers, and the Cherokee, Catawba, and Creek, as well as colonial provincials of North Carolina who were conducting a vicious war upon them. The Tuscarawa became the sixth member of the Iroquois League, hence the more common moniker—Six Nations. ${ }^{16}$ By 1717 the Covenant Chain grew to include the Creek Nation as they decided to ally themselves with the League. ${ }^{17}$ In the same year the League continued with its free rider strategy by declaring allegiance to both the British and French Kingdoms who were collectively at war with Spain. ${ }^{18}$

Yet, by the 1730s, the Six Nations would endure another exodus as League Seneca, among others, and in addition to Seven Nations emigrants, relocated to the Ohio River Valley in which two new nations were erected independently of the League, these being the Mingo and the Sandusky Seneca nations. ${ }^{19}$. The tribal nations of the Susquehanna Valley in Pennsylvania were also weary of the Six Nations and the Covenant Chain and began migrating to Ohio. By the late 1730s, approximately 2500 ethnic Abenaki, Ottawa, Ojibwa, and Delaware, along with ethnic members from the original five member nations of the Iroquois League the Mohawk, Oneida, Onondaga, Cayuga, and Seneca settled on the Cuyahoga River in northern Ohio. By the early 1740s, the Beaver, Muskingum, Ohio, Tuscarawa, and Scioto rivers hosted Shawnee, Mingo, and Delaware communities. ${ }^{20}$ 
These ex-Covenant Chain nations in Ohio produced an intertribal polity that became the basis for a containment nationalist movement that eventually reached beyond the confines of the Ohio River Valley as the Shawnee related a personal invitation to tribal nations of the Illinois country including the Wea, Miami, Kickapoo, and others, "Come to see us all, my brothers, and to be united as one people». ${ }^{21}$ On a significant level, tribal nations were driven into a containment nationalist strategy and polity as they sought to avoid national integration into a foreign order engineered by an ensemble of agents seeking to employ grand designs of subjugation, territorial expansion, and wealth creation upon and through the tribal nations.

Covenant Chain mediation in practice offered an illusion of protection for the clients of the Six Nations and an illusion of equity for member nations interests. In 1736 the Six Nations strengthened its partnership with Pennsylvania by entering into a treaty with undisclosed provisions wherein Pennsylvania would recognize the Six Nations as the official representatives of the Delaware and any other tribal nation on Pennsylvania's borders. ${ }^{22}$ While the colonies courted the Six Nations, they did not extend any diplomatic courtesies nor politesse to other tribal nations. Notice in 1732, a treaty process between Governor Belcher of Massachusetts Bay and the Penobscot and other nations in which premature responses were demanded and deliberation for consensus was prohibited. Common Amerindian protocol such as gift exchanges or ceremonial use of wampum were also barred from the negotiations. ${ }^{23}$

In the summer of 1742, Pennsylvania hosted a treaty session in Philadelphia that included League Onondaga, Cayuga, Oneida, Seneca, and Tuscarawa. League client nations were represented by the Shawnee, Nanticoke, and Delaware. The central issue to resolve was land 
claims by both native and colonial parties. One such assertion by colonial authorities involved a claim to the Forks of the Delaware River that had been allegedly purchased decades before. The declined the offer to vacate the territory. The issue was considered and League representative and Onondaga headman Canassatego resolved:

You ought to be taken by the Hair of the Head and shak'd severly till you recover your Senses and become Sober...Your Cause is bad, your Heart far from being upright, and you are maliciously bent to break the Chain of friendship with our Brother Onas [Thomas Penn]... ${ }^{24}$

But how came you to take upon you to sell land at all? We conquered you; we made women of you; you know that you are women and can no more sell land than women; nor is it fit that you should have the power to sell land since you abuse it. This land that you claim is gone through your guts. You have been furnished with clothes, meat and drink by the goods paid you for it; and now you want it again like children as you are... ${ }^{25}$

Canassatego continued to embarrass Nutimus of the Delaware council by declaring League rights to lands south of the Kittatinny Mountains. Despite the Six Nations overarching influence on Delaware affairs, if one were to peer back further into North American history one would find that the Iroquois League was initially created in response to Delaware power as suggested through Delaware oral traditions. ${ }^{26}$ Therefore the storyline may be more complex when considered from a longer timeline which may also be true for the entire region of TransAppalachia. In other words, the apparent autocrat of the moment may have formerly been the exploited recipient and vice versa, but not necessarily so. Regardless, free rider nationalism in lieu of the Covenant Chain and the Iroquois League operated from an intertribal orientation with varying degrees of membership ranging from complete participation in the decision making process to a subjugated role that relegated certain tribal polities to respite their own affairs to the authority of other parties. The benefactors of the Covenant Chain, the Six Nations and the 
colonies of England, practiced a diplomatic form of nonrecognition to preserve their mutual and exclusive interests. In this manner the League’s free rider and non-alignment strategy was possible, as they provided legitimacy to colonial directives with other tribal nations. In other words, western legal traditions were upheld through the Covenant Chain, but these legal practices should not be mistaken for just and equitable practices.

During the 1740s, in the Ohio Country, the League had granted widespread trading courtesies to the English and authorized the construction of trade facilities on the Cuyahoga, Sandusky, and Miami Rivers. The Miami Nation was even brought into the trade network. Trade operators included George Croghan. The League began institutionalizing governance over the Ohio country by appointing local Mingo leaders to positions of rank and assigning specific land tracts to the various native inhabitants. ${ }^{27}$ By 1745 the benefactors of the Covenant Chain met in Albany to treat with one another. Representatives from the League, Massachusetts, Connecticut, Pennsylvania, and New York aimed to secure native participation in the enduring trade conflict with the French. Mohawk Chief Hendrick reported his thoughts to the various native peoples of the Covenant Chain:

We, the Mohawks, are your fathers and you are our children. If you are dutiful and obedient, if you brighten the chain with the English our friends and take up the hatchet against the French our enemies, we will defend and protect you; but otherwise if you are disobedient and rebel you shall die every man, woman, and child and that by your hands. We will cut you off from this earth as an ox licketh up the grass. ${ }^{28}$

Hendrick’s speech marks a turning point in League leadership from the Onondaga to that of Mohawk headsmen operating in close association with Sir William Johnson. What emerged from this relationship was a new Covenant Chain. ${ }^{29}$ In due course the new order would favor the 
English and betray the League's diplomatic preference for insistent non-alignment between England and France. This was probably the primary factor in the eventual collapse of the League. William Johnson obtained more influence than previous colonial officials as he went about building separate covenant chains, in the 1750s, with other League members and the tribal nations of Ohio and Pennsylvania. By 1760 Johnson had established a separate council fire of deliberation in Detroit with the nations of the interior without consulting League officials. Alas, Sir William Johnson, on the surface and in appearance to other colonial officials, began enlarging the Covenant Chain by bringing in new member nations. In reality, however, he was building new diplomatic institutions attached to him and not typical of previous diplomatic configurations involving the League. ${ }^{30}$

However, the League's ability to follow through with the implementation and management of the Covenant Chain has probably been historically overstated. ${ }^{31}$ The League intervention into the Ohio trade with the English effectively motivated the French to attempt a dismantling of the League's ability to continue with a strategy designed to curtail both French and English authority in the region. In 1752 the English trading post hosted by the Miami was sacked and pro-League Miami Chief Old Britain was killed by Franco-Amerindian forces. Three years earlier the French, with great technological sophistication and cunning, buried their lead plates into the soil of the Ohio country — the plates themselves proclaiming title to the land for King Louis. ${ }^{32}$ The French had plans for the Ohio country, plans that was free of League and English interference 
Through the month of June in 1754, the English colonies hosted a conference at Albany to build upon their alliance with the Six Nations and gain favor with other native nations per instructions from the Board of Trade, although colonies such as Virginia would forsake attendance at the conference. ${ }^{33}$ Nonetheless, much of the conference was dedicated to Benjamin Franklin's Plan of Union. The Plan of Union hoped to achieve a unification of the English colonies to provide for an integrated defense in the event of war with France. The colonies were in a state of disarray, having never jointly cooperated to frustrate French schemes. "The problem was to overcome the jealousies of the various colonies and to get them to unite...”34

Recommendations from the Albany Conference included an organized expansion beyond the Appalachian Mountains wherein current colonial borders would be restricted for the creation of new colonies. Conference attendees also issued a reprimand concerning the inability of some colonies to contend with any concentrated effort against the French. Other agenda items included temporarily suspending western expansion by placing a restrictive border along the backside of the colonies, and the potential reorganization of Indian diplomatic affairs. Sir William Johnson recommended fortifying Six Nations lands with garrisons to protect from French intrusions, and notified other colonial authorities of League expectations in expelling the French from the Ohio Country. ${ }^{35}$

In the meantime, the Lords of Trade in England were in the midst of creating yet another version of a colonial plan. This plan called for the King to appoint a single person as Commander in Chief, and for Indian Affairs to rest under this authority. Furthermore, this plan detailed the creation of additional frontier forts, and a method to recruit additional soldiers in the event of an 
attack upon the colonies. British Imperial Policy originating in the events of the colonies and of various governmental agencies in England itself where a myriad of interests, events, and indecisiveness prevented a coherent consensus. The crucial interests to consider in British policy originated in private enterprises such as corporate land charters, incorporated colonial charters, and so on. In part, these layers of policy explain the discontinuity among the colonies themselves, and with their home government in England. ${ }^{36}$

Pennsylvania, in 1758, made an offer to return all lands purchased from the Six Nations at the 1754 Albany Conference with the hope of ending the raids being conducted by native forces in the Ohio country and made further overtures concerning a hunting preserve in Ohio. ${ }^{37}$ Pennsylvania had been making such offers as early as 1756, as the war had not been going well for the colonies. At the conclusion of the $2^{\text {nd }}$ Treaty of Easton, George Croghan left Pennsylvania and joined Sir Johnson in the Mohawk Valley to repair the Covenant Chain with the Six Nations so that the chain of friendship could again be employed in future deliberations with the Ohio natives. ${ }^{38}$ The Covenant Chain, as once engineered through League diplomatic maneuvering, would never again serve the Six Nations as it had in the past. The French were to be defeated; hence the League could no longer stage-manage the French and English with misleading claims and actions. Even so, the League through the Covenant Chain would still serve the colonial goal of western expansion. The structure of the struggle changed after the war. No longer were the French a frontier threat and no longer would the colonies need to rely so heavy upon the League as a buffer to New France. The new frontier diplomatic structure would increasingly involve the Amerindian leadership of the western interior. 
With the defeat of New France in 1760, Six Nations, through Sir William Johnson, attempted to reinstitute the Covenant Chain in terms of Six Nations supremacy over other tribal nations. This worked to a very limited degree as the strategic reality forced Superintendant of Indian Affairs Sir William to conduct diplomatic labors and trade regulation directly with Ohio natives who had been victorious in preserving their position during the war, and with the former members of the Franco-Amerindian regime. The military, trade, and diplomatic posts of Detroit, Fort Pitt (Pittsburgh), and Michilimackinac became the new centers of Indian affairs as Six Nations' influence waned. The new state of affairs also left Britain with a multitude of problems as Britain now claimed title to all previous French settlements and presumed to have a vested authority over the natives located west of the Appalachian Mountains. Simply, the British just did not have the institutional structure in place, nor the manpower to execute colonial authority over such a broad area. ${ }^{39}$ Nor did the British, as later events would reveal, have the means to quell the appetite of its own colonial subjects for the resources and land of the North American interior.

The events of 1761 highlight the growing division among the League’s member nations. League Seneca began plans to launch an attack of Fort Detroit. ${ }^{40}$ In the interim, Sir William Johnson hosted a meeting with the Mohawk at his house to inform them of his forthcoming trip to Detroit where he was going to call upon the Ottawa Confederacy, along with other local nations, to settle a treaty of peace and trade on behalf of General Amherst. ${ }^{41}$ Before leaving, Sir William also parlayed a conference with some Onondaga chiefs of the League who stated:

We are surprised at your going to call a council at Detroit, when you know that the chief and only council fire burns at your house and Onondaga; besides these Indians you are going to, 
ought rather, as being aggressors, to come to you. You recommend it to us to mind our hunting and trade, and live in friendship with our brethren at the several posts. It is what we would be very desirous of, but they, by their behavior to us at the several posts, seem not to have any liking for us, and use us very ill at times without any cause, taking our women from us by violence, using them and us ill besides, and hindering us from fishing and hunting on our own grounds near the posts, and often taking what we catch or kill from us. This is not agreeable to the promises made us, or the friendship so long establishing between us and you. We beg, brother, you will interpose and see justice done us... ${ }^{42}$

Later during the actual trip to Detroit, a pair of Mohawk pleaded with Sir William not to continue into what they considered to be inhospitable country. They further warned of a potential attack on his party due to Sir Williams' association with the Mohawk who were regarded as Englishmen by the tribal nations in the vicinity of Detroit. ${ }^{43}$ In the meantime, Guyasuta, an uncle to the prophet Handsome Lake, and a number of other Seneca, took a wampum belt of war from the Council of the Onondaga to Detroit. In Detroit, they called upon the Ottawa, Huron (Wyandot), Ojibwa, and Potawatomie to come together with the League in a synchronized surprise campaign to capture British garrisons at Detroit, Fort Pitt, Presqu’le Isle, Niagara, and Venango. The Delaware and Shawnee were also invited, but refused to participate and foiled the plans by revealing the scheme to the British commander at Detroit. The Seneca revived the plan in 1763 by sending red wampum belts to the Miami on the Wabash River, the Shawnee and Delaware on the Ohio River, and the tribal authorities located in the vicinity of Detroit. ${ }^{44}$ 
${ }^{1}$ Camenzind, K. (2002). "From the Holy Experiment to the Paxton Boys: Violence, Manhood, and Race in Pennsylvania during the Seven Years War.” Dissertation at the University of California, San Diego. Ann Arbor, Michigan, USA: UMI.

${ }^{2}$ Dowd, G. E. (1986). "Paths of Resistance: American Indian Relgion and the Quest for Unity, 1745-1815, Volumes 1 \& 2." Dissertation at Princeton University . Ann Arbor, Michigan, USA: UMI.

${ }^{3}$ Camenzind, K. (2002).

${ }^{4}$ Wallace, Anthony F.C. with the assistance of Sheila C. Steen. (1972). The Death and Rebirth of the Seneca. New York: Vintage Books, a Division of Random House.

${ }^{5}$ Wallace, Anthony F.C. with the assistance of Sheila C. Steen. (1972).

${ }^{6}$ Dowd, G. E. (1986).

${ }^{7}$ Hatheway, G.G. "The Neutral Indian Barrier State a Project in British North American Policy 1754-1815." Dissertation at the University of Minnesota. Ann Arbor, Michigan: UMI, 1957.

${ }^{8}$ Haan, R. L. (2003). Covenant and Consensus Iroquois and English 1676-1760. In Beyond the Covenant Chain, The Iroquois and Their Neighbhors in Indian North America 1600-1800. Daniel Richter and James Merrell, Editors. University Park, Pennsylvania: The Pennsylvania State University Press.

${ }^{9}$ Angela Goebel Bain, Lynne Manring, and Barbara Mathews. (2008). Lesson Two Native Peoples in New England. Retrieved 2008, from Memorial Hall Museum Online American Centuries: www.memorialhall.mass.edu/classroom/curriculum_6th/lesson2/bkgdessay.html

${ }^{10}$ Haan, R. L. (2003).

${ }^{11}$ Richter, D. K. (1984). "The Orderal of the Longhouse: Change and Persistance on the Iroquois Frontier 16091720." Dissertation at Columbia University . Ann Arbor, Michigan, USA: UMI.

${ }^{12}$ Freeman, S. (2004). "The Land Systems of Colonial America, European and Native American Land Tenure Issues in the Colonial Eras of the Americas.” Dissertation at West Virginia: Morgan Town, West Virginia . Ann Arbor, Michigan, USA: UMI.

${ }^{13}$ Wallace, Anthony F.C. with the assistance of Sheila C. Steen. (1972).

${ }^{14}$ O’Callaghan, E. B., ed. (1855). Documents Relative to the Colonial History of New York; Procured in Holland, England and France by John Romeyn Brodhead, Esq., Vol V. Albany, New York: Weed, Parsons, and Company, Printers. Page 274.

${ }^{15}$ Edward, D. (1988). "Colonial Indian Wars." In Handbook of North American Indians Volume 4. William C. Sturtevant \& Wilcomb E. Washburn, Editors: Smithsonian Institution: Washington, D.C.

${ }^{16}$ Richter, D. K. (1984).

${ }^{17}$ Freeman, S. (2004). 
${ }^{18}$ Richter, D. K. (1984). "The Orderal of the Longhouse: Change and Persistance on the Iroquois Frontier 16091720." Dissertation at Columbia University . Ann Arbor, Michigan, USA: UMI.

${ }^{19}$ Benn, C. E. (1995). "The Iroquois in the War of 1812." Dissertation at York University . North York, Ontario, Canada: UMI.

${ }^{20}$ Dowd, G. E. (1986).

${ }^{21}$ Dowd, G. E. (1986).

${ }^{22}$ Wallace, P. A. (1996). Conrad Weiser Freind of Colonist and Mohawk 1696-1760. Lewisburg, Pennsylvania: Wennawoods Publishing.

${ }^{23}$ De Puy, H. F. (1917). A Bibliography of the English Colonial Treaties with the American Indians: Including a Synopsis of Each Treaty. New York: Printed for the Lenox Club.

${ }^{24}$ Original Document. Canasatego’s Speech to the Delaware, 1742. 2003. ExplorePAhistory.com. http://explorehistory.com/odocument.php?docId=266. Retrieved July 2009.

${ }^{25}$ De Puy, H. F. (1917). Page 17.

${ }^{26}$ Grimes, R. S. (2005). "The Emergence and the Decline of the Delaware Indian Nation in Western Pennsylvania and the Ohio Country 1730-1795." Dissertation at West Virginia Univeristy. Ann Arbor, Michigan, USA: UMI.

${ }^{27}$ Wallace, Anthony F.C. with the assistance of Sheila C. Steen. (1972).

${ }^{28}$ De Puy, H. F. (1917). Page 25.

${ }^{29}$ Haan, R. L. (2003).

${ }^{30}$ Haan, R. L. (2003).

31 Jennings, F. (2003). Pennsylvania Indians and the Iroquois . In Beyond the Covenant Chain. The Iroquois and Their Neighbors in Indian North America 1600-1800. Richter, Daniel K. and James H. Merrell, Editors. University Park, Pennsylvania: The Pennsylvania State University Press.

${ }^{32}$ Wallace, Anthony F.C. with the assistance of Sheila C. Steen. (1972).

33 Beer, George Louis. (1933). British Colonial Policy 1754-1765. New York: Peter Smith. (Reprinted by Special Arrangement with the MacMillan Company: 1907)

${ }^{34}$ Beer, George Louis. (1933). Page 18.

${ }^{35}$ Hatheway, G. (1957).

${ }^{36}$ Hatheway, G. (1957). 
${ }^{37}$ Parmenter, J. W. (1999). "At the Wood's Edge: Iroqouis Foreign Relations 1727-1768." Dissertation at the Univeristy of Michigan . Ann Arbor, Michigan, USA: UMI.

${ }^{38}$ Hatheway, G. (1957).

${ }^{39}$ McConnell, M. N. (2003). People in Between; The Iroquois and the Ohio Indians 1720-1768. In Beyond the Covenant Chain. The Iroquois and Their Neighbors in Indian North America 1600-1800. Richter, D. K. and James H. Merrell, Editors. University Park, Pennsylvania: The Pennsylvania State University Press.

${ }^{40}$ Camenzind, K. (2002).

${ }^{41}$ Hamilton, M. W. (1962). The Papers of Sir William Johnson Volume XIII. Albany, New York: The University of the State of New York.

${ }^{42}$ Hamilton, M. W. (1962). Page 223.

${ }^{43}$ Hamilton, M. W. (1962).

${ }^{44}$ Wallace, Anthony F.C. with the assistance of Sheila C. Steen. (1972). 


\section{Chapter 6-The Nations of the Ohio}

Many Amerindians lived in the locales of English forts, settlements, and trade stations in western Pennsylvania. These inhabitants were notified to evacuate in advance of upcoming military operations targeted for the region. The notification extolled the Rationale that if Amerindian inhabitants in these areas chose to stay they would be considered kin to the English and suffer the potential consequences. In 1755, Shingas, a Delaware leader from the Ohio Country, proceeded with accompanying Shawnee and Mingo leaders to meet with the British Majesty’s General Braddock to discover British Intentions should they defeat the FrancoAmerindian regime. General Braddock informed that "the English Should Inhabit and Inherit the Land.”1 When Ackowanothic, another Delaware leader during the war, was asked why the Ohio Nations were assaulting the British, he responded that the French could be removed at any time, but that their participation in the war would help offset the numerical superiority of the British. ${ }^{2}$

Other recent events also gave purpose for the tribal nations of Ohio to enter into war with the British. The Shawnee and Delaware suffered a number of depredations. One instance transpired in South Carolina where The Pride, a Shawnee leader who had been warring with the Catawba, was apprehended and later died in prison in 1753. A second instance cropped up when Shawnee and Delaware ambassadors approached Pennsylvania concerning Iroquois League land sales. Pennsylvania exercised great diplomatic skill by taking the ambassadors into custody, whereby they proceeded to hang the delegation of Shawnee and Delaware. In due time, the French reported the circulation of Shawnee and Delaware war belts without deliberation or 
consultation with French authority. ${ }^{3}$ These events, in light of even earlier episodes wherein the Delaware and Shawnee had been politically marginalized by the Covenant Chain, seems to have left them fairly contemptuous of alliances with either the French or the English. Earlier, at the turn of the century, the Shawnee in the Cumberland region of Tennessee had come under great pressure from League attacks. ${ }^{4}$

From the early days of the French and Indian War, nationalist strategies in the borderlands of Trans-Appalachia can be observed to materialize in two prominent and dynamic forms that originate in a vein of self-preservation. Tribal nationalism may be seen to have developed in a prolonged and acute period of crisis brought on by an inequitable trade system with Europeans and a dwindling population base due to disease and famine, keeping in mind that native populations were not buttressed with a constant supply of new members stemming from immigration to offset their losses as were the British colonies. Not to mention the issue of constant warfare, loss of hunting and agricultural lands, or the domestic slave trade. The slave trade cannot be underestimated, for as far back as the early 1700s, census figures indicate that Kingston, Rhode Island of the New England colonies alone contained a population of 233 Indian slaves and 335 African slaves contrasted against a population of 835 free Europeans, for example. $^{5}$

The balance between trade dependency eventually favored colonial authorities. Unavoidably, trade relations translated into a political currency that would empower and alter native polities in an inequitable fashion, giving rise to a host of interesting characters and strange bedfellows. The fur trade, and trade in general, became a source of division among and between 
tribal polities, as it had also served as a source of rivalry among European Kingdoms. The trade itself often lacked equity for tribal participants, which further exacerbated the trade imbalance or dependence in favor of colonial traders. French dominance in the Northwest fur trade ended in 1760. The British would retain control of the Northwest fur trade only temporarily, as it would lose the Great Lakes portion of the trade to the American Republic by the early 1780 s. ${ }^{6}$ On the other side, Europeans and colonials were also dependent on trade with natives, though not in the critical area of manufactured arms and weapons, which acted to the disadvantage of tribal nations. Additionally, the colonies became less reliant on trade with natives as the colonies matured and grew with continual immigration.

*Revisiting the concept of the containment strategy to describe one vein of tribal nationalism, the reader may notice a polity that often valued intertribal participation and communion accompanied with an objective to retain an existence where it could decide its own terms and conditions in maintaining territorial integrity that utilized alliances at times with various European authorities to advance tribal agendas, though initially such alliances would not be entered into until after the French and Indian War. In the case of the Ohio nations, another factor stands out. Many of these nations or bands had restored themselves from unfavorable and marginal status conditions as they had previously suffered significant defeats at the hands of the Iroquois League in earlier decades. While tribal nations needed allies, the crippling reality was to ask if there existed any allies worth having? Eventually, some individual tribal units that operated in this manner would themselves surrender the fight by either voluntarily moving 
further west, typically beyond the Mississippi River, or by taking a nonalignment posture in an attempt to avoid further conflict.

Another vein of tribal nationalism was built around an appeasement or cooperation strategy. Tribes employing this strategy sought to achieve territorial integrity and tribal sovereignty by emphasizing the individual tribal unit, but at the same time providing admission to their internal polity to direct participation by non-native authorities through colonial annuity and trade system. This was sometimes the choice of the tribe, but it also occurred through elicit persuasion, or through diplomatic coercion with the backing of colonial power. Direct participation by foreign agents into native polities provided a primary means by which the American Republic could model, shape, and endorse tribal governments that in return would acquiesce and consequently support the nationalist movement of western expansion consistent with an appeasement stratagem. Tribal nations utilizing an appeasement strategy would also intermittently find cause to support their containment counterparts, while on other occasions they would find cause to counter the designs of the containment regime of the Old Northwest and Old Southwest. The appeasement strategy became more common at the completion of the American Revolution, and was not so much in use during or immediately after the French and Indian War. Moreover, tribal nations practicing appeasement diplomacy attempted, on occasion to also practice a nonalignment style of diplomacy seeking retention of their rights. As the crisis of western expansion became more acute, any non-alignment approaches became extremely difficult. 
From this dichotomy of containment-oriented tribal polities and appeasement polities, a crucial issue of identity arises, an issue that I think still permeates tribal and American culture today. Both polities over the entire course of the Proclamation Wars developed intimate relations with Europeans through marriage, adoption, captive-taking, holding of slaves, trade and security relations. Through these elaborate social practices, the definition of whom and what is Indian, tribal, American, Native American and so on, emerged. Importantly, the definitions that hold the most validity only do so through those individuals and institutions that retained formal sociopolitical power. In this respect, these identities may always remain contested.

It has been suggested that the Delaware and Shawnee, of the Ohio country, participation in an alliance with New France provided the opportunity for an extended tribal consensus. This consensus included other tribal allies of New France, such as the Ottawa, Ojibwa, Wyandot, certain bands of the Miami, and Illinois regional tribes, and even members of the Six Nations League. However, at this time the Franco-Amerindian security regime, and the British equivalent in the form of the Covenant Chain, already existed in which the Ohio nations had established themselves as an independent entity. Shawnee and Delaware members would maintain resistance to an alliance with New France. Earlier in 1749 the Shawnee had contemptuously removed French stakes indicating a Royal claim to the Ohio River Valley. ${ }^{7}$ In 1745 the Shawnee were noted to be the "most restless of all the Indians" and had been in communication with New Spain. ${ }^{8}$ By 1759 the tribal authorities of Ohio sought and requested the removal of both French and English troops from the Ohio River Valley. ${ }^{9}$ Between 1755-1757 the related and simultaneously independent efforts of the Franco-Amerindian Security Regime and 
the Ohio tribal nations had enjoyed great success against the British in the Illinois and Great Lakes regions. However, their cooperation buckled at the moment the French asked and expected native leaders to serve under the command of regular French officers. ${ }^{10}$

In the summer of 1755, forces under British General Braddock, Commander in Chief of British forces in North America, were entirely routed during the Battle of the Wilderness near Fort Duquesne. Braddock’s force consisted of 1,200 British regulars and colonial militia under the command of Colonel George Washington. Approximately 300 would survive the ordeal having been led to safety by Colonel Washington. General Braddock was counted among the dead. ${ }^{11}$ General Braddock’s command had been operating without the assistance of indigenous scouts that may have prevented such a disaster. The "Indian Scout Dilemma" led to the organizational development at the unit level of light infantry. ${ }^{12}$ Native scouts and light infantry, such as colonial ranger units, often served larger forces in crucial reconnaissance roles. By May of 1756 the new Commander in Chief of British forces in North America, Governor Shirley, created the American Ranger Company, more commonly known as Rogers’ Rangers. Eventually the outfit would include a company of Mohican natives. ${ }^{13}$

British administrator, Sir William Johnson, with League Mohawk and a substantial force of colonial militia, established Fort William Henry near Lake George of colonial New York in September of $1755 .{ }^{14}$ Within the next two years both Fort Oswego on the banks of Lake Ontario, and Fort William Henry would also fall to Franco-Amerindian armies. Fort William Henry was surrendered when its troops were offered terms that included safe passage from the fort by General Montcalm. The retreating column included British Regulars, elements of Rogers’ 
Rangers, and colonial militia. Montcalm's Amerindian allies did not agree with his terms of surrender and attacked the column, inflicting heavy casualties while also taking prisoners. However, at this apex of success, the French forts became logistically challenged and in dire need of supplies necessary to continue operations. These unfavorable conditions would persist for the remainder of the war to the detriment of the French.

By July of 1758, a British force consisting of such units as the $42^{\text {nd }}$ Black Watch Highland Regiment, Rogers' Rangers, and some 9000 colonial militia proceeded to capture the key Fort Carillon (later Fort Ticonderoga) whose location granted control of the lakes and waterways of Upper New York. The British force endured a 60\% causality rate. Control for Upper New York was costly, as a year and a half earlier Rogers' Rangers had advanced up to Lake Champaign only to suffer substantial losses at the Battle of Barbue Creek. ${ }^{15}$ The Fort Carillon campaign was part of Prime Minister William Pitt's strategy to make over the war as a contest between regular European forces. Pitt enjoyed additional victories at Louisburg and Fort Duquesne. ${ }^{16}$ His success was due more to the adverse French logistical situation than to his application of strategic aspirations, unless you consider his utilization of the British navy to deprive New France of its supply lines. Yet another potentially equivalent source to French logistical problems was French officials themselves who confiscated and hoarded agricultural products for their own private gain. These officials, such as Bigot, also failed to forward supplies to the French forts. ${ }^{17}$ When British regulars and colonial militia under Colonel Washington marched on Fort Duquesne, they did so to only find it abandoned by the French. ${ }^{18}$ Fort Duquesne 
was renamed Fort Pitt and transformed into an eighteen acre compound. The campaign had cost $1 / 2$ million pounds. ${ }^{19}$

Earlier in the fall of 1755, the tribal nations of Ohio associated with the containment strategy provided the Christian Indians of the Gnadenhutten Mission a forewarning to evacuate before executing the destruction of the mission in which eleven Moravian missionaries were killed. The tribal leaders of Ohio probably viewed the mission as a front for colonial operations. Frontier colonials also held reservations towards the mission. They assumed and accused the native converts at the mission of spying on behalf of the Ohio tribal nations. ${ }^{20}$ These tribal nations probably viewed the Moravian institution as an unwelcomed intrusion upon their internal national affairs. Furthermore, the tribal leaders of Ohio may have considered the Moravian activities as something akin to witchcraft, as the missionaries actively sought to not only erase cultural native affiliations, but to also literally change the spiritual paradigm from which natives understood the world and themselves. Finally, the Moravian missionaries were probably considered to be acting beyond a supposed spiritually benevolent role, and viewed as apparent colonial agents in the contest for the Ohio country.

In 1756 Sir William Johnson began holding conferences with various tribal nations to reassert British influence in light of recent failures in the war effort. Johnson had communicated to the Six Nations of his desire for them to exercise control over the warring Delaware who were theoretically dependents of the Six Nations. Johnson further added that if the Six Nations were to hesitate in exerting their authority over the Delaware they would find themselves involved in a much larger war. ${ }^{21}$ Johnson proceeded to enter a treaty with some Delaware and Shawnee known 
as the first Treaty of Easton. Delaware sachem and Moravian mission convert, Teedyuscung, met with Pennsylvania’s Governor Robert Morris to discuss the fighting on the Pennsylvania frontier, whereupon Teedyuscung agreed to parlay for peace with other elements of the Delaware nation. Sir William Johnson pressured the Six Nations and entered into a treaty in hopes of stopping the devastation on the Pennsylvania frontier being caused by factions of Delaware and Shawnee. ${ }^{22}$

By January of 1757, at a conference hosted at Fort Niagara, Delaware leaders would contemptuously offer their symbolic petticoats, significant of their status as women by League standards, back to the Six Nations headsmen. The Delaware suggested that the Iroquois should adorn them for not openly declaring their loyalties in the current conflict. Other Ohio attendees included members from the Shawnee and Mingo Nations. ${ }^{23}$ The ethnic Iroquois of Ohio, otherwise known as the Mingo, residing within the intertribal villages of the Shawnee and Delaware, quit responding to the leadership of the Six Nation's council by the 1760s, and maybe even earlier as indicated by the Fort Niagara conference. At one point, the Six Nations invited the Mingo to relocate in a closer proximity to the towns of the Six Nations, but the offer was not accepted. $^{24}$

Nonetheless, the stage was set for new peace talks. In the fall of 1758, the Ohio factions of Delaware and Shawnee entered into the Second Treaty of Easton with Pennsylvania. ${ }^{\mathrm{A}}$ The Shawnee and Delaware agreed to stop fighting. In return, British Pennsylvania agreed not to establish any settlements west of the Allegheny Mountains, a stretch of the broader Appalachian

\footnotetext{
${ }^{A}$ The return of prisoners initiated by the Treaty of Easton reunited the brothers Simon, James, and George Girty. In order they had been adopted and raised by the Seneca, the Shawnee, and the Delaware.
} 
Mountain Range. The Ohio nations also agreed to a return of their colonial prisoners. Hatheway suggests the $2^{\text {nd }}$ Treaty of Easton marked a shift in British Indian Policy as the affluent Penn family of Pennsylvania had agreed to yield all their land titles null and void west of the Appalachia crest. Here the effects of the war forced a shift in colonial policy. ${ }^{25}$

Prior to and during the French and Indian War, another demographic trend began to emerge. The Ohio tribal nations, who held League authority in disdain, began to entertain and host new tribal migrants from the southern tribal nations of the Old Southwest Region. In 1752 a number of Cherokees journeyed north to council with the Shawnee on the Ohio River. They foretold of a desire to relocate over 1,000 of their kinsmen to settle among the Shawnee; these Cherokees had been accused of murdering English traders, although they denied any role in the matter. By 1755, a group of Cherokee did relocate to the intersection of the Ohio and Kentucky Rivers. $^{26}$ The towns of this area would be known by its neighbors as the Indian Republics. ${ }^{27}$ This region, bounded in the north by the Great Lakes, in the west by the Wabash River, in the south by the Ohio River, and in the east by the Appalachian Mountains, was where more migrant tribal nations would gather to form a resistance movement that eventually spanned generations and covered nearly the entire length of the Appalachia Range.

Other tribal nations to enter this region included the Mascoutens, Kickapoo, Miami, Wyandot, and Creek. Logstown was a principal republican community. Conrad Weiser, in reference to Logstown’s citizenry, stated they were, “very jealous at one another, they being of so many different nations. Each of them pretending to have as wise people as the rest."28 Attempts were made by the French to affix the Indian Republics to form a joint frontier security 
bloc, but to no avail. The Cayuga of the Iroquois League informed French representatives that the republics were now a part of the landscape. ${ }^{29}$ Any British intention of gaining favor with the tribal nations of Ohio faded when Virginians travelled to Logstown to notify Tenachrissan that, by the tenants of the 1744 Lancaster Treaty, the Iroquois League had transferred the land rights of western Pennsylvania, western Virginia, and Kentucky to the jurisdiction of Virginia. The Virginia representatives hoped to gain recognition of the Lancaster Treaty and the approval of Logstown's tribal authorities in order to begin settlement of said territories. Virginia's representatives fell short of their goals. ${ }^{30}$

While the Ohio Nations agreed to a separate peace with the Easton Agreements, it was in 1762, at Lancaster, where an additional treaty was concluded. The Lancaster Agreement required the removal of both the English and French from the Ohio region, yet General Forbes left a garrison at Fort Pitt to protect British trade interests. For the Ohio Nations, the accord may be seen as an early victory in their quest to retain independence from foreign powers, whether colonial or tribal in origin. Yet the Ohio Nations were not held in high regard, as one Pennsylvanian reflected of the republics as "ye Scum of the Earth...this mixed dirty sort of people.”31 By this time, the Ohio Nations, like the League, began to consider the British and the French as a solitary Christian danger to their well being, even a "conspiracy". ${ }^{32}$

Around 1761, near the end of the French and Indian War, notification was received by British authorities of forthcoming plans to contend with British intrusion in the region. This notification originated from a Creek town located on the Sandusky River. ${ }^{33}$ While the current war was coming to a close, Neolin, the Delaware Prophet, began to foretell of an impending war 
with England. ${ }^{34}$ During the summer of 1762, a grand council was hosted by an Ottawa town north of Detroit attended by the most venerated leaders of the interior nations. ${ }^{35} \mathrm{~A}$ year later Pontiac's War would begin in which tribal members of the former Franco-Amerindian Alliance, along with current members of the British-Amerindian Covenant Chain, and the independent nations of the Ohio region, participated in a loosely unified effort to evict the British from the interior. Here cooperation among Amerindian society prevailed. 
${ }^{1}$ Bond Jr., Beverly. (Jun-1926). The Captivity of Charles Stuart 1755-1757. The Mississippi Valley Historical Review. Vol 13. No 1 pp. 58-81. Page 63

${ }^{2}$ Okerson, B. B. (1996). "Weyapiersenweh Blue Jacket, War Chief of the Shawnees and the Contest for Possession of the Ohio River Valley." Dissertation at the University of Memphis . Ann Arbor, Michigan, USA: UMI.

${ }^{3}$ White, R. (1991). The Middle Ground: Indians, Empires, and Republics in the Great Lakes Region 1650-1815. New York, New York: Cambridge University Press 1991.

${ }^{4}$ Crane, Verner W. (1916). The Tennessee River as the Road to Carolina: The Beginnings of Exploration and Trade. The Mississippi Valley Historical Review, Vol 3 No 1 pp 3-18.

${ }^{5}$ Graves, William Hilton. "The Evolution of American Indian Policy." Dissertation at Florida State University. Ann Arbor, Michigan: UMI, 1982.

${ }^{6}$ Stevens, W. E. (Sep 1916). The Organization of the British Fur Trade 1760-1800. The Mississppi Valley Historical Review, Vol 3 No 2 pp 172-202.

${ }^{7}$ Dowd, G. E. (1986). "Paths of Resistance: American Indian Relgion and the Quest for Unity, 1745-1815, Volumes 1 \& 2." Dissertation at Princeton University . Ann Arbor, Michigan, USA: UMI.

${ }^{8}$ Harvey, H. (1855). History of the Shawnee Indians, From the Year 1681 to 1854, Inclusive. Cincinnati, Ohio: Ephraim Morgan and Sons. Page 64.

${ }^{9}$ Parmenter, J. W. (1999). "At the Wood's Edge: Iroqouis Foreign Relations 1727-1768." Dissertation at the Univeristy of Michigan . Ann Arbor, Michigan, USA: UMI.

${ }^{10}$ Okerson, B. B. (1996).

11 encarta. (2008). Edward Braddock Encyclopedia Article. Retrieved March 2008, from MSN encarta: encarta.msn.com/encyclopedia_761573699/Edward_Braddock.html

12 Mahon, J. K. (1958). Anglo-American Methods of Indian Warfare 1676-1794. The Mississippi Valley Historical Review, Vol 45 No 2 pp. 254-275. Page 266.

${ }^{13}$ Bluhm, J. C. (2004). U.S. Army a Complete History. Arlington, Virginia: Hugh Lauter Levin Associates, Inc.

${ }^{14}$ Bluhm, J. C. (2004).

15 Bluhm, J. C. (2004).

${ }^{16}$ Hahn, S. C. (2000). "The Invention of the Creek Nation: A Political History of the Creek Indians in the South's Imperial Era 1540-1763." Dissertation at Emory University . Ann Arbor, Michigan, USA: UMI.

${ }^{17}$ A.G. Doughty and N.E. Dionne. (1903). Quebec Under Two Flags. Quebec: The Quebec News Company.

\& Gilbert Parker and Claude G. Bryan. (1904). Old Quebec. New York: The Macmillan Company. 
${ }^{18}$ Bluhm, J. C. (2004).

${ }^{19}$ McClure, J. P. (1983). "The Ends of the American Earth: Pittsburgh and the Upper Ohio Valley to 1795” (Volumes 1 \& 2). Disseratation at the University of Michigan . Ann Arbor, Michigan, USA: UMI.

${ }^{20}$ Camenzind, K. (2002). "From the Holy Experiment to the Paxton Boys: Violence, Manhood, and Race in Pennsylvania during the Seven Years War.” Dissertation at the University of California, San Diego. Ann Arbor, Michigan, USA: UMI.

${ }^{21}$ De Puy, H. F. (1917). A Bibliography of the English Colonial Treaties with the American Indians: Including a Synopsis of Each Treaty . New York: Printed for the Lenox Club.

${ }^{22}$ De Puy, H. F. (1917).

${ }^{23}$ Parmenter, J. W. (1999).

${ }^{24}$ McClure, J. P. (1983).

${ }^{25}$ Hatheway, G. (1957). “The Neutral Indian Barrier State a Project in British North American Policy 1754-1815.” Dissertation at the University of Minnesota . Ann Arbor, Michigan, USA: UMI.

${ }^{26}$ Tanner, H. H. (Spr 1978). Cherokees in the Ohio Country. Journal of Cherokee Studies, Vol 3 No 2 pp 94-102.

${ }^{27}$ White, R. (1991).

${ }^{28}$ Wallace, Paul A. (1996). Conrad Weiser Friend of Colonist and Mohawk 1696-1760. Baltimore, Maryland: for Wennawoods Publishing by Gateway Press, Inc. (originally published 1945: Philadelphia, Pennsylvania) Page 267.

${ }^{29}$ White, R. (1991).

${ }^{30}$ White, R. (1991).

${ }^{31}$ Wallace, Paul A. (1996). Page 270.

${ }^{32}$ White, R. (1991). Page 237.

${ }^{33}$ Dowd, G. E. (1986).

${ }^{34}$ Okerson, B. B. (1996).

${ }^{35}$ Macfarlane, P. (1999). Two French Threats to North America 1760-1783 as seen by British Colonial Officials. Dissertation at Concordia University, Montreal, Quebec, Canada. 


\section{Chapter 7-The Path to Civilization}

In the later years of the French and Indian War, Prime Minister William Pitt planned to remove the French presence in the Old Southwest through a combined tactical land and sea campaign. Fort Loudon would be the source of the land campaign, hosted by the Cherokee Nation. The naval campaign would embark from South Carolina via the Mobile and Mississippi Rivers. The British hoped to capture Fort Toulouse, deep in the territory of the Creek Nation. The operation was never initiated. The Creek Nation's non-alignment posture barred such actions. Superintendant of Indian Affairs in the southern colonies, Edmund Atkin, failed with his diplomatic overtures to carry the Creek into British favor. The Creek did not necessarily herald the French cause either, for their employment of a non-alignment strategy preempted European attempts at undermining Creek autonomy. Different methods were employed by the Creek to maintain a non-alignment posture that included the utilization of multiple trade agreements, and the holding of commissions by tribal leaders from the various European authorities.

The Creek Nation of that generation held steadfast to a decision of impartiality that had been reached by their ancestors in the Coweta Resolution. Hahn notes the difficulties of such a strategy, as it mandated an unswerving degree of consensus and application of military

deterrence. ${ }^{1}$ However, these factors of consensus and application of military deterrence may not be so unique to this strategy in the context of indigenous North American culture that valued 
consensus building approaches to decision making and therefore these factors may be relevant to many sorts of strategies.

Commissions were often granted by the various colonial authorities to individual native leaders. Commissions could entail one time monetary or trade payments, annual payments, or some other form of compensation. Individuals holding commissions usually held some title or rank useful to European agents. In this manner holders of a commission often acted as point men or men of arbitration in various diplomatic and trade settings. Amerindian leaders exploited commissions to advance various national interests regarding both domestic and foreign matters; simultaneously, commissions provided Europeans with the means to advance their own national agendas within tribal nations. A similar instrument was employed by native authorities who would adopt colonial men of influence into their tribes (such as Indian Agents or traders) or firmly connect them to their tribes through marriage. In this manner, security and trade regimes were developed according to the national interest of all parties. These sorts of arrangements often provided the ample opportunity for uneven associations and unwarranted relationships.

While Edmund Atkin was busy trying to develop a pro-British native consensus, The Mortar (an early Trans-Appalachia advocate for intertribal nationalism) of the Creek Nation was active in trying to create a consensus that favored the containment strategy. Atkin described The Mortar as “too Indian.” Characteristically, Atkin considered The Mortar as, “the compleatest Red man in principle” for The Mortar scoffed at the opportunity to hold a colonial granted commission. $^{2}$ The Mortar represents a type of tribal nationalism that in large part held colonial authoritative and cultural institutions in a severe state of contempt even in the arena of treaty 
making as witnessed in later generations of containment leaders. One can only peer so far into The Mortar's personal politics and motives, but a survey of the state of affairs in the Old Southwest might provide some answers.

In the early 1700s a delegation of Cherokee traveled to South Carolina to meet with the royal governor to discuss the problem of slave raiders. Eventually the slave trade for South Carolina would commercially trump other sources of trade such as that of the fur trade. Author Minges describes the Carolinian involvement in the slave trade as “...an orgy of slave dealing that decimated entire peoples. Carolina was more active than any other colony in the exportation of Indian slaves.”3 A little over a decade later Creek slaving parties were so successful at acquiring Cherokee slaves that it became necessary for the Cherokee to negotiate an arrangement with the Spanish benefactors of Creek slaving. Scholar Drew records, "Over time Indian slaves were lumped together with blacks in plantation records under the general heading 'slave' an erasure of their ethnic identity.”4 Ongoing tribal hostilities in the Old Southwest were probably so lengthy in duration as a direct result of the colonial slave trade and potentially could be considered a series of ongoing slave trade wars or conflicts.

In 1708 the Carolinas were populated by 5,300 whites, 2,900 African slaves, and 1,400 Amerindian slaves. ${ }^{5}$ During the early and mid 1700 's, Crown officials became worried over the ethnic demographics of their colonies, especially in South Carolina where they felt the Ratio of free whites to slaves was to narrow in that the risk of rebellion became too great. The officials issued a directive to encourage the importation of white contract laborers who would eventually be entitled to land grants of 50 acres for either female or male servants upon the fulfillment of 
their service contracts. These grants of land would also, for 10 years, be removed from paying quit-rents (taxes) to the Crown. The same sort of scheme was endorsed by the Crown in provincial Virginia in the late 1600s and early 1700s, except the grant of land to white indentured servants was only 30 acres. ${ }^{6}$ From such practices, British policy developed and produced expectations that were not consistent with such landmark policy innovations as the Royal Proclamations of 1763.

In 1720 Britain's Board of Trade and Plantations primed a set of reports on the subject of the South Carolina colony which formed the original intentions of frontier policy. The plans called for the construction of forts along the southern colonial borders and upon the rivers Tennessee, Altamaha, and Chattahoochee. The placement of western forts was intended to prevent French encroachments from both Louisiana and Canada. Other expansionist designs included the acquirement of territories west and south of the Savannah River although European title to these lands was contested not only by France, but also by Spain. ${ }^{7}$ Early on South Carolina's colonial status was indeed delicate; therefore, the provincial assembly determined, "the safety of this Province, under God, does depend on the friendship of the Cherokees." The Cherokee, like other borderland tribes, were of strategic concern for both England and France. The British made a concerted effort to gain tribal allies along their colonial borders to prevent raids into Virginia, the Carolinas, and Georgia by the Amerindian, French, or Spanish rivals. By gaining borderland allies, the British could create a buffer territory to protect burgeoning colonial populations and otherwise feeble colonies. ${ }^{9}$ 
The Cherokee sent a delegation of seven representatives to England, and in 1730, the British Crown and the Cherokee delegation entered into the Articles of Agreement. The compact required the Cherokee to provide exclusive trade rights to England along with rights of settlement whereas South Carolina was required to supply any trade goods the Cherokee Nation wanted. ${ }^{10}$ Such agreements offer a potential source or historical basis to appeasement strategies that relied upon trade and land concessions. Other stipulations conferred upon the Cherokee included recognition of the Crown's sovereignty, the extradition of any Cherokee guilty of murdering an Englishman, and the extradition of any slave who had run away. The King of England also granted the Cherokee with the right to domicile at their pleasure. The delegation included the young Attacullacullah. With the exception of the 1760-61 conflict, the English Crown and the Cherokee maintained a half century long alliance. ${ }^{11}$ The villages and towns of the Cherokee Nation, at the time of the agreement and for some length of time after the agreement, had been largely free of colonial traders and any other foreign guests whether of English, French, or Spanish origins. ${ }^{12}$

In the summer of 1746, South Carolina Governor James Glen offered, per instruction from the Crown, to construct a stronghold in the Overhill Towns of the Cherokee Nation, as the Upper Creeks and some Choctaw had been actively raiding Cherokee territory. By 1748, Cherokee headmen were requesting the construction of an Overhill fort. The benevolence of the Cherokee had been a fundamental condition to the success of the royal colony of South Carolina. The deerskin trade alone numbered as one of South Carolina's top exports, even though traders routinely cheated the Cherokee. By 1753 Governor Glen had erected Fort Prince George near 
Keowee Town, but it was an insufficient deterrent to enemies of the Cherokee. The early years of the 1750s witnessed trade disputes with South Carolina merchants that escalated into violent reprisals, and the continual desolation of the eastern Lower Towns by Creek forces, as well as further depredations on the Cherokee from Shawnee war parties. ${ }^{13}$ From this antagonistic environment, the leaders of Chota an Overhill Town:

...assumed national leadership by concluding a long-desired peace with the French Indians, by formulating a new British alliance brilliantly designed to end the Carolinian monopoly with a rival Virginia trade... and by shielding the murderers of traders behind protracted diplomatic maneuvers...They also persuaded the British to build a fort in the Overhills to protect Cherokee women and children, before anymore warriors were recruited... ${ }^{14}$

The rout of Braddock’s forces in the Franco-Amerindian summer campaign of 1755 in the Old Northwest, and the British desire to recruit tribesmen to serve with British field armies, further prompted the construction of Fort Loudon in the Overhill Towns. ${ }^{15}$ Add to this other events, like the Shawnee parties actively attacking the Carolina frontier settlements and taking Catawba prisoners in late 1754, further hastened Fort Loudon's construction. ${ }^{16}$ During this time, the quarter century long Cherokee quarrel with the Muscogee Confederacy (Creek Nation) ended, leaving portions of upper Georgia and Alabama within the territorial confines of the Cherokee Nation. The Cherokee also defeated other tribal nations in the Carolinas, including the Catawba. ${ }^{17}$ All the while, Superintendant Edmund Atkin continued on a course to reinvigorate British policy towards gaining favor with all the tribal nations in the south.

Atkin hoped to achieve an imposing British-Amerindian alliance by bringing the various tribal nations into a security and trade regime through his personal efforts. However, the colonies themselves were against any sort of Amerindian-Colonial bloc. Atkin reported in 
writing to the English Board of Trade the basis for French success in building effective relationships with tribal nations. The report listed:

1) A standardized and uniform French policy.

2) Technological provisions to Amerindian communities such as gun smiths.

3) The acknowledgement of Amerindian leadership and status through gift giving.

4) The French practice intolerance of unwarranted behavior being inflicted toward Amerindian communities and individuals.

All this is in contrast to an undeveloped or well thought out British policy. Atkin was motivated to move forward. Accompanying the report was his notes regarding the:

Direction \& Management of the Indian Affairs throughout North America, under one uniform Regulation of their Commerce, for retrieving \& establishing the British Interest among the Indian Nations, \& thereby the future Security of our Colonies against the Designs of the French. ${ }^{18}$

The construction of Fort Loudon across from Chota on the Little Tennessee River's west bank was completed in the summer of 1756, but it was not garrisoned, so the Cherokee shortly put the fort to ruins. ${ }^{19}$ Meanwhile, after holding talks with the Cherokee, The Mortar reported, "which is that the English has now a Mind to make slaves of them all for [they] have already filled their nation with English forts and great Guns, Negroes, and Cattle." ${ }^{20}$ That summer Cherokee headman Osteneco (Judd's Friend) led war parties against the Shawnee north of the Ohio River, but with little success as the Shawnee only captured a Cherokee known as The Thigh. While the Cherokee would endeavor to engage the northern Shawnee, they would cease any hostilities with the southern Shawnee domiciled in Creek territory. ${ }^{21}$ Various bands of Shawnee had resided among the Creek Nation for years. The Shawnee band associated with 
Peter Chartier lived on the Coosa River. A decade earlier Chartier had taken a French commission, while at the same time taking advantage of Pennsylvania traders with his credit line, and then further taking the liberty to add insult to injury by looting English traders. Chartier probably never intended to carry out the duties of his French commission as he had opposed and avoided the relocation of the Shawnee to Detroit, and thus into the Franco-Amerindian Alliance. ${ }^{22}$ Two other band members, the Bride and Big Huminy, were at odds with Chartier over his questionable behavior, but nonetheless, the band retired from the northern country in 1747 to join other southern Shawnee. Over time the Shawnee became an important diplomatic nexus between the tribal nations of the Old Northwest and the Old Southwest. ${ }^{23}$

In the later summer of 1756 a Creek party with The Mortar, also with some southern Shawnee, and Mankiller from the Cherokee Town of Tellico (another Overhill Town of distinction) ventured to the French Fort Toulouse down the Coosa River to parlay with the French. The intertribal delegation desired the French to construct a fort in the vicinity of Tellico. From here some members of the Tellico party journeyed to New Orleans for supplies while others visited the Shawnee towns on the Coosa River. At these Shawnee towns an alliance was formed, and members from each nation proceeded to erect a village thirty miles southeast of Tellico on the Hiwassee River. The alliance waned as logistical problems ensued. ${ }^{24}$ Tellico Town became a host for many Shawnee people. ${ }^{25}$ Like their neighbors in the north, elements of the southern tribal nations began to organize a containment-oriented nationalist movement that was intertribal in scope. 
By January of 1757, the new Fort Loudon was constructed and manned, but it was now positioned at the entrance of the Tellico River just south of the Little Tennessee River, otherwise known as the Cherokee River. ${ }^{26}$ In this year the Cherokee initiated hostilities with the Chickasaw Nation that would end a decade later to the detriment of the Cherokee. The Cherokee had become overstretched, as they were also at war with the Seneca and Shawnee north of the Ohio River, during a time when small pox was also taking a toll on village populations. ${ }^{27}$ Fort Loudon further obligated the Cherokee to tax their resources, and by the summer of 1758 around 700 Cherokee warriors were serving with the British in every theater of the French and Indian War. ${ }^{28}$ Individual Cherokee gunmen were compensated by British authorities with scalp bounty payments. $^{29}$

General Forbes was accompanied by 400 Cherokee during his Fort Duquesne campaign at the Forks of the Ohio. The British-Cherokee Alliance fell on hard times when Virginia settlers murdered a number of Cherokee. In retaliation, the Cherokee took vengeance upon a number of settlers in the Carolinas, which prompted an embargo of weaponry on the Cherokee Nation by Governor Lyttelton. ${ }^{30}$ Previous treaty commitments required colonial authorities to seize and bring the murderers to trial, but Virginia failed to do so. ${ }^{31}$ Attacullacullah, the leader of the Cherokee force attached to General Forbes, decided to depart for home, but Forbes had other plans; by force, he temporarily detained Attacullacullah. ${ }^{32}$ The episode would eventually escalate into a full scale war between the Cherokee Nation and the southern colonies in 1759 that lasted until $1761 .^{33}$ Later on, Virginia's failure to prosecute the murderers was turned on its head when citizens of provincial Virginia preempted any formal proceedings by partaking in a jail break that 
freed the accused. The mob professed publically, "that the killing of a savage is an action for which no man ought to suffer."34

In April of 1759, The Mortar lobbied for the support of the Overhill Towns in his operations against the English. ${ }^{35}$ The Overhill and Valley Town divisions of the Cherokee Nation aided The Mortar in building a rendezvous camp on the Coosa River for Creek, French, Cherokee, and other allied forces in preparation for an attack on Fort Loudon. The Mortar's town was located adjacent to the Etowah mound, hence the town name-Etowah Old Town or Etowhatchee, located in the proximity of present day Cartersville, Georgia. The Mortar and his uncle, a headman of Cussita, obtained most of their support from their own kin. Hahn suggests the continental movement towards intertribal nationalism was promoted through a labyrinth of kin networks. ${ }^{36}$ Tellico, home of the Emperor and Mankiller, had once been in the 1730s the lead Overhill Town in matters of national affairs, and had formerly enjoyed strong ties to Britain. Attacullacullah's associate, Old Hop or Conocorte, would routinely impose gun powder embargos on towns such as Tellico for not supporting pro-British policies. ${ }^{37}$

In December, Governor Lyttelton’s colonial army held Cherokee hostages at Fort Prince George including Oconostota. After Attacullacullah was able to obtain Oconostota’s liberation, the pair of them treated with Governor Lyttelton and agreed to extradite any Cherokee citizens responsible for killing settlers. Oconostota began unrestrained warfare on South Carolina once Lyttelton’s army had journeyed back to Charlestown. By the following spring in 1760, Oconostota laid siege to Fort Loudon. A relief force under William Byrd III was organized in Virginia, but it never got afoot. Another relief force in South Carolina, numbering around 1,600, 
successfully departed only to be turned back by an ambush in June. A number of the besieged men in Fort Loudon had Cherokee wives who routinely broke the ongoing siege by providing the fort with food. ${ }^{38}$ The Cherokee wives aiding the fort "laughed" when Cherokee warriors expressed their contempt. ${ }^{39}$ Attacullacullah himself, walking a diplomatic tightrope, betrayed Oconostota as he served the fort by acting as the primary source of information. In return, Attacullacullah was removed from the Council of the Cherokee, having been identified as an Englishman. ${ }^{40}$

Oconostota traveled to New Orleans in February of 1761, where he received a French commission with the rank of captain. Oconostota further asked for technical support in the use of cannon captured from the British. ${ }^{41}$ Oconostota’s ties to the French went back decades earlier, as he had developed a trade partnership with Priber, a French envoy, although Priber was eventually apprehended by the English in 1743. Priber's fate was an untimely death at Frederica Prison in provincial Georgia. ${ }^{42}$ The Cherokee sought to expand their campaign, as they sent spokesmen north of the Ohio to encourage the Shawnee, Delaware, and Seneca to enter into an alliance against the British. Their efforts failed when the British were forewarned of the scheme.

The Cherokee delegation also approached the Wyandot, Ottawa, Ojibwa, and Pottawatomie Nations to dissuade them from conducting any further raids on the Cherokee. Their efforts had some effect, as the Shawnee began stopping war parties that were enroute to Cherokee territory. The Miami and Wyandot would continue with the raids. ${ }^{43}$ The early days of Trans-Appalachian intertribal containment-oriented nationalism fell short of its intended consensus, but never before had such a consensus even been attempted. In the future, the attempt 
to gain a lasting consensus would have to navigate substantial obstacles such as logistics, a loss or lack of viable European allies, existing political orders such as the Covenant Chain, and the emergence of a unified thirteen colonies. Problematically, it would also be politically tempting for a member of the consensus to defect for short term gains, seeking temporary advantages and benefits through other relations. Such defection would sorely plague the containment consensus. Other problems also hampered efforts, such as the slave trade, and an ever increasing rate of tribal rivalries intensified by the fur trade, a primary means by which tribal nations acquired European weaponry.

Late in the summer, the men serving during the siege of Fort Loudon started to desert and endangered their officers with the possibility of complete abandonment of the post. The surrender of the fort ensued shortly thereafter. The survivors were allowed to return to their homes in the colonies of Carolina and Virginia. Two hundred forty men and women embarked for Fort Prince George. In retaliation for the killing of Cherokee hostages during the siege, Osteneco ambushed the Fort Loudon party, killing three officers and twenty three privates. A few women also fell victim to Osteneco's attack. Other members of the Fort Loudon siege were ransomed to either South Carolina or Virginia. Colonel James Grant proceeded with a new campaign into Cherokee territory that drove some 5,000 Cherokee into the mountains after having toppled fifteen towns, and burning at least 1,500 acres of corn. As a result, in the winter, Attacullacullah was reinstated into his position on the Cherokee National Council where he went forward with a peace settlement. The postscript of the entire action included the French expedition's failure to navigate the Suck of the Tennessee River, hence they were never able to 
garrison the temporarily deserted Fort Loudon, and thus the lack of their presence would prevent them from gaining favor with the Cherokee. ${ }^{44}$ Years later, the Cherokee would give away territory in Tennessee, Kentucky, and the Carolinas to erase their trade debts with the southern colonies. $^{45}$

Events such as the forced dislocation of 5,000 Cherokee from their homes provides an excellent basis for understanding why tribal bands began voluntarily migrating west or moving north and south. It also makes me wonder if all 5,000 returned to their former homes. In 1776, the Seneca River in central New York hosted a Cherokee refugee camp, and colonial practice of taking Indian captives added to the problem of dislocated Amerindian families and individuals. Indian captives included children and women who often became farm laborers or were sold into slavery. ${ }^{46}$ In 1777, around 500 Cherokee refugees were reported in Pensacola, Florida where they expressed their intentions to fight with the British. ${ }^{47}$ The dislocation of Amerindian populations was widespread and the ethnic composition of Amerindian nations during this time frame became more diverse to the point of initiating or creating identity issues another element to consider in the discourse on identity.

By the 1750s, a large number of displaced Natchez tribesmen took residence in the Cherokee Nation. The Natchez were kinsmen, as far as Cherokee headman the Raven was concerned. ${ }^{48}$ Conditions in the Old Northwest were much the same. In 1753, in western Pennsylvania at the Amerindian town of Shamokin, a missionary noted, "it is uncomfortable for Indians there, for if they plant they cannot enjoy it, so many strange Indians pass through the town whom they must feed." ${ }^{49}$ The Chickamauga towns not only hosted intertribal allies, but 
also hosted refugees from Cherokee towns further east. Eventually, these towns even became home to Tory refugees during the American Revolution as well as a number of blacks. ${ }^{50}$ Decades later, after the formal removal of the Old Southwest tribes to Oklahoma, a band of Delaware surrendered their tribal autonomy, status, and identity. They were coercively compelled to accept Cherokee leadership and the recognition of their children as Cherokee citizens if they were going to subsist within the jurisdiction of the Cherokee Nation. ${ }^{51}$ 
${ }^{1}$ Hahn, S. C. (2000). "The Invention of the Creek Nation: A Political History of the Creek Indians in the South's Imperial Era 1540-1763." Dissertation at Emory University . Ann Arbor, Michigan, USA: UMI.

${ }^{2}$ Hahn, S. C. (2000). Page 561.

${ }^{3}$ Minges, P. ( 2001). Beneath the Underdog: Race, Religion, and the Trail of Tears. American Indian Quarterly , Vol 25 No 3 pp. 453-479. Page 454.

${ }^{4}$ Drew, B. (2001). "Master Andrew Jackson: Indian Removal and the Culture of Slavery." Dissertation at Yale University. Ann Arbor, Michigan, USA: UMI. Page 21.

${ }^{5}$ Graves, William Hilton. "The Evolution of American Indian Policy." Dissertation at Florida State University. Ann Arbor, Michigan: UMI, 1982.

${ }^{6}$ Labaree, Leonard Woods. (1935). Royal Instructions to British Colonial Governors 1670-1776, Volume II. New York and London: D. Appleton-Century Company Incorporated.

${ }^{7}$ Crane, V. W. (1925). Project for Colonization in the South 1684-1732. The Mississippi Valley Historical Review , Vol 12 No 1 pp. 23-35.

${ }^{8}$ Kelly, J. C. (1978). Fort Loudoun: British Stronghold in the Tennessee Country. The East Tennessee Historical Society's Publications, No 50 pp. 72-91. Page 72.

${ }^{9}$ Kelly, J. C. (1978).

${ }^{10}$ Pate, J. P. (1969)."The Chickmauga: A Forgotten Segment of Indian Resistance on the Southern Frontier." Dissertation at Mississippi State University . Ann Arbor, Michigan, USA: UMI.

${ }^{11}$ Pate, J. P. (1969).

12 Rothrock, M. U. (1979). Carolina Traders Among the Overhill Cherokees 1690-1760. East Tennessee Historical Society's Publications , No 51 pp. 14-29.

${ }^{13}$ Stumpf, S. (1978). James Glen, Cherokee Diplomacy, and the Construction of an Overhill Fort. The East Tennessee Historical Society's Publications , No 50 pp. 21-30.

${ }^{14}$ Stumpf, S. (1978). Page 26.

15 Stumpf, S. (1978).

${ }^{16}$ Dowd, G. E. (1986). "Paths of Resistance: American Indian Relgion and the Quest for Unity, 1745-1815, Volumes 1 \& 2." Dissertation at Princeton University. Ann Arbor, Michigan, USA: UMI.

${ }^{17}$ Haggard, D. R. (2006). "Their Own Way of Warring": The Making and Persistence of Cherokee and Muscogulge Identity 1500-1800. Dissertation at the Univeristy of Kansas-Lawrence Campus . Ann Arbor, Michigan, USA : UMI. 
${ }^{18}$ Jacobs, Wilbur R., Editor. The Appalachian Indian Frontier. The Edmond Atkin Report and Plan of 1755. Columbia, South Carolina: University of South Carolina Press. 1954. Page 77.

${ }^{19}$ Kelly, J. C. (1978).

${ }^{20}$ Saunt, C. (1996). "A New Order of Things: Creeks and Seminoles in the Deep South Interior 1733-1816." Dissertation at Duke University. Ann Arbor, Michigan, USA: UMI. Page 80.

${ }^{21}$ Dowd, G. E. (1986).

${ }^{22}$ White, R. (1991). The Middle Ground: Indians, Empires, and Republics in the Great Lakes Region 1650-1815. New York, New York: Cambridge University Press 1991.

${ }^{23}$ White, R. (1991).

${ }^{24}$ Dowd, G. E. (1986).

${ }^{25}$ Stone, J. R. (1969). Captain Paul Demere at Fort Loudon 1757-1760. The East Tennessee Historical Society's Publications, No 41 pp. 17-32.

${ }^{26}$ Kelly, J. C. (1978).

${ }^{27}$ Haggard, D. R. (2006).

${ }^{28}$ Kelly, J. C. (1978).

${ }^{29}$ Dowd, G. E. (1986).

${ }^{30}$ Kelly, J. C. (1978).

${ }^{31}$ Eliades, D. K. (1981). "The Indian Policy of South Carolina 1670-1763." Dissertation at the University of South Carolina . Ann Arbor, Michigan, USA: UMI. Page 232.

${ }^{32}$ Dowd, G. E. (1986).

${ }^{33}$ Piecuch, J. R. (2005). "Three Peoples, One King: Loyalists, Indians, Slaves, and the American Revolution in the Deep South 1775-1782." Dissertation at the College of William and Mary . Ann Arbor, Michigan, USA: UMI.

${ }^{34}$ Labaree, Leonard Woods. (1935). Page 473.

${ }^{35}$ Stone, J. R. (1969).

${ }^{36}$ Hahn, S. C. (2000).

${ }^{37}$ Dowd, G. E. (1986).

${ }^{38}$ Kelly, J. C. (1978). 
${ }^{39}$ Finger, J. R. (1995). Tennessee Indian History: Creativity and Power. Tennessee Historical Quarterly, Vol 54 No 4 pp. 286-305. Page 297.

${ }^{40}$ Kelly, J. C. (1978).

${ }^{41}$ Franklin, N. W. (1977). Oconostota, Cherokee Chieftain, Receives a Military Commission From Kerlerec, Louisiania Governor, 1761: French Text and English Translation. East Tennessee Historical Society's Publications , No 49 pp. 3-7.

${ }^{42}$ Pate, J. P. (1969).

${ }^{43}$ Dowd, G. E. (1986).

${ }^{44}$ Kelly, J. C. (1978).

${ }^{45}$ Haggard, D. R. (2006).

${ }^{46}$ Sheidley, Nathaniel J. Unruly Men: Indians, Settlers, and the Ethos of Frontier Patriarchy in the Upper Tennessee Watershed, 1763-1815. (Dissertation at Princeton University: New Jersey. 1999.)

${ }^{47}$ Piecuch, J. R. (2005)

${ }^{48}$ Galloway, Patricia and Jason Baird Jackson. Natchez and Neighboring Groups. Handbook of North American Indians. Raymond D. Fogelson, Editor Vol 14 Southeast pp 598-615. (Smithsonian Institute: Washington, D.C. 2004.).

${ }^{49}$ No Author. “A Missionary’s Tour to Shamokin and the West Branch of the Susquehanna 1753.” Pennsylvania Magazine of History and Biography. 1915. Vol 39. No 4. pp 440-444.

${ }^{50}$ Finger, J. R. (1995). Page 297. \& Pate, J. P. (1969).

${ }^{51}$ Grimes, Richard S. (2005) "The Emergence and the Decline of the Delaware Indian Nation in Western Pennsylvania and the Ohio Country 1730-1795." (Dissertation at the West Virginia University.2005). 


\section{Chapter 8-Montreal Union}

After the Paris Convention that ended the Seven Years War, France and her ally Spain did not incur a total loss. Spain had become formally involved in the affair after England declared war on Spain in 1762. In the treaty, Spain retained Cuba, and France regained the sugar islands Martinique, Guadeloupe, and St. Lucia. While France and Spain had sustained a devastating blow to their imperial and colonial ambitions, they would not be thwarted in the future from participating in any opportunities to recoup their losses.

Initially the French were led into the war by the Ottawa. ${ }^{1}$ The Franco-Amerindian Alliance included the Ottawa, Ojibwa, Potawatomi, and the Menominee from their countries located in the western portion of the Great Lakes region. Seven hundred Ojibwa, Ottawa, and Potawatomie participated in the defeat of General Braddock. ${ }^{2}$ The Western Wendat or Wyandot, an incorporation of formerly distinct northern Iroquoian peoples not associated with the Great Peace that created the Five Nations Iroquois League, were also a primary agent in the French association. ${ }^{3}$ These core members were associated with the Michilimackinac trade and defense centers along with other centers such as Detroit. French policy developed around a doctrine of accommodation for its native allies. ${ }^{4}$

The Franco-Amerindian security regime emerged from an earlier set of wars in which the Iroquois League defeated both the French and various Wendat peoples such as the Huron, Neutral, and Petun. ${ }^{5}$ During the 1600 and 1700s, the conflict between the French with the 
Iroquois League often looks to be a personal contest between League Mohawk and the French. Indecision within the League over foreign policy regarding New France and disagreements over the incorporation of remnant Huron families, which led to some tense political drama during the 1650s. On different occasions League members, the Onondaga and Seneca made attempts to arrange a peace with the French. During these peace discussions the Mohawk attendees acknowledged their responsibility in the murder of one Onondaga chief and the accidental killing of a Seneca ambassador. These acts were unconventional but served to aid in securing the Mohawk interests at the talks. The Mohawk were also accused of additionally killing two other Seneca in the sorted affair. ${ }^{6}$

By the 1680s, the French and the Western Lake Nations formalized their association through an alliance to counter the League's influence. The French feared a sort of domino effect in that if one nation fell to the League, then eventually all the nations would fall as far as Green Bay, leaving French Canada exposed to the designs of the League and their British ally. The French were prescribed an arbitration duty within the alliance and were relied upon for logistical support. $^{7}$ The population of French Canada was $1 / 20$ the size of the British colonies. ${ }^{8}$ The French were at an obvious disadvantage without membership in a collective security regime. This provides a practical explanation for France’s willingness to recognize and cooperate with tribal authority.

Samuel de Champlain, an originator of policy for New France, keyed in on the role of the fur trade. Champlain vied for French mastery of native culture, language, and tradition as compulsory for the preservation of the fur trade and the security alliance. He further sought to 
indulge New France's native allies as contemporaries in political and commercial affairs. Many individual ethnic French intermarried and adopted native customs, forming a new ethnic culture known as the Métis. ${ }^{9}$ New France stretched from the North Atlantic to the Gulf of Mexico through the Great Lakes down the Mississippi River. Cities included Detroit, St. Louis, Natchez, and New Orleans. There were also a number of smaller communities such as those along the Illinois River. New France was nestled and surrounded by a vast Amerindian presence. Amerindian communities controlled the flow of commerce through New France. Simply, the demographics favored tribal populations in that the disparity between the sizes of French colonies and the numerous native communities precluded the agendas of French officials. ${ }^{10}$ In line with the demographic reality of the interior country, the French Catholic Jesuits were also hard pressed in their spiritual endeavors as native communities viewed such dealings as not suitable to them. ${ }^{11}$

French congeniality did not extend beyond the reach of her immediate native allies, as Montreal alone at some point received about 60 native slaves annually through the security regime. ${ }^{12}$ Similar to the English Covenant Chain, the institution of slavery working in the confines of the Franco-Amerindian alliance served political agendas in addition to traditions of colonial economy. In the 1680s, the French Crown authorized enslavement of League citizens as a means to advantage the French position in North America. The Crown authorities stated that during conflicts in which prisoners would be acquired, they should be sent to France to serve in the "Galleys". 13 
Through trickery and deceit, rather that open warfare, Lamberville, a Catholic Priest and member of the mission serving the Onondaga, succeeded in capturing 36 Onondaga and Oneida chiefs in addition to their diplomatic compliment that included additional League citizens. Lamberville’s success was achieved by extending an invitation to negotiate a peace at Fort Frontenac. Governor of New France, Denonville wanted the incarcerated delegation sent to France, whereas Lamberville desired to retain the captives as potential leverage in future talks with the League. ${ }^{14}$ The League, in many respects, did not appreciate the presence of intrusive French authority;

...if that be a good title [reference to French claims] then we can claim all Canida, for we not only did soe, [that is, they conquered it] but subdued whole nations of Indians that liv'd there, and demolished there castles in so much, that now great oake trees grow where they were built, and afterwards we plyed the French home in the wars with them, that they were not able to go over a door to pisse. We are the just and rightful owners of all our lands and these which the French now pretend...

Nevertheless, the French endeavored to bring about the demise of the League and employed multiple methods to do so. For one, they initiated an arms escalation by constructing new forts on League lands. From these forts, the Catholic missionaries would begin to depopulate the League itself by relocating converts to mission towns located in New France. New France would continue to arm its native allies as a deterrent to League influence in economic trade. The League responded by enticing New France’s native allies to conduct trade with the English or the Dutch of New York. League officials encouraged traders to undercut French prices as an incentive to gain market share. Lastly, the League took to war with the Huron, Illinois, Miami, and Ottawa nations to drive a wedge between them and the French. ${ }^{16}$ 
Alarmed by a potential peace between New France and the League, in the summer of 1695 the Ottawa and Huron (Wyandot) entered into secret negotiations with the League. By doing so, the Ottawa and Huron would gain better trade terms with the English. ${ }^{17}$ A lasting peace between the League and New France had been attempted in the previous decade, but The Rat of the Western Wyandot used his statecraft to block any such outcome. The Rat organized an ambush of Iroquois peace delegates, assassinating many of them, while others were allowed to survive. The survivors fell into The Rat's ruse: the surviving delegates were under the impression that the ambush was requested by the French governor himself, rather than an independent act committed by The Rat. The Rat further held one hostage, whom he delivered to a French fort conveying to the fort's commandment that the hostage was an Iroquois spy. By these means, the war continued. ${ }^{18}$ The Rat was the individual that de Callieres, Governor of Canada, instrumentally relied upon in the maintenance of the Franco-Amerindian security regime. ${ }^{19}$ It has been stated of The Rat, that “...he was the type of man to manage the most ticklish affairs of a flourishing state. ${ }^{20}$ A year later the League would push for the English to enter into war with New France. Dozens of raids were undertaken by both the League and the Franco-Amerindian alliance. On three separate occasions, the League sent forces of over 1,000 men against the colony of New France, killing or capturing around 600 people. In addition, they made raids on tribal nations aligned with the French. ${ }^{21}$ League officials stated to their Covenant Chain partners:

We are now down upon one knee, but we are not quite down upon the ground; let the Great King of England send the great canoes with seaventy guns each, and let the brethren of Virginia, Maryland, Pensilvania, the Jerseys, Connecticutt and New England awake, and we will stand up 
straight againe upon our feet; our heart is yet stout and good; we doubt not but to destroy the enemy...We are not able of ourselves to destroy them. We are become a small people and much lessened by the war. If the people of Virginia, Maryland, Pensilvania, the Jerseys, Connecticutt and New England who have put their hand to the Covenant Chain will joyne with the inhabitants of this place [New York], we are ready to go and root out the French and all our enemies out of Canida. $^{22}$

The war was more than fruitless for the League. They failed to bring New France’s native allies into the Covenant Chain, but also substantially weakened their own influence with the English. Late in the decade, the French and English agreed upon terms of peace, even though, against British protest, the French would not allow the League to participate in the treaty proceedings. The League would have no choice but to seek a separate peace with New France. ${ }^{23}$ In the summer of 1701, The Great Peace of Montreal was concluded with 39 tribal nations and New France. Over 1,200 signatories endorsed the document. Here, the League agreed to remain neutral in future conflicts between the French and the English, another probable source of their future nonalignment and free rider foreign policy strategies. The Rat of the Wyandot, once an opponent to any sort of peace, now used his diplomatic dexterity to bring about such a peace. At the Montreal Conference:

He spoke at length, and being naturally eloquent, no one perhaps ever exceeding him in mental capacity, he was heard with boundless attention. He described with modesty, and yet with dignity, all the steps he had taken to secure a permanent peace among all the nations; he made them see the necessity of such a peace, and the advantages it would entail on the whole county in general and each tribe in particular, and with wonderful address showed distinctly the different interests of each. Then turning towards the Chevalier de Callieres, he conjured him so to act that no one thereafter cold reproach him with abusing the confidence placed in him. ${ }^{24}$

The Montreal Peace lasted a little over a decade and a half. The Rat died during the Montreal Convention. Upon his loss, a French official stated: 
His nation felt the extent of the loss it suffered, and it was the general opinion that no Indian had ever possessed greater merit, a finer mind, more valor, prudence or discernment in understanding those with whom he had to deal. His measures were always found wise, and he was never without resource; hence he always succeeded. ${ }^{25}$

The Great Peace of Montreal, in consensus-driven terms, defined the nature of the relationship between New France and her Amerindian allies for the remainder of New France’s tenure in North America. In this respect, the Franco-Amerindian Alliance may better be represented or befitted with the description The Montreal Union, much as the counter diplomatic apparatus between Iroquois League and the British was known by the moniker The Covenant Chain. Montreal was host to the annual fur trade fair for over a century and a half, in which some Amerindian hunters traveled over a thousand miles to attend. ${ }^{26}$ The Montreal Peace also afforded a place at the table so to speak for France’s tribal enemies. The British Royal Proclamation of 1763 worked towards a similar end, but unlike the Montreal Peace, it considered Amerindian populations as British subjects even though it addresses Amerindian polities as nations. The Montreal Peace reflected legitimate international relations, as European and Amerindian nations participated in its construction., Meanwhile, the Royal Proclamation was constructed by English politicians and delivered to Amerindian society without consulting directly with Amerindian leaders. In fact, it was the opinion of the French governor that the success of the Montreal Peace hinged on the diplomacy of The Rat. ${ }^{27}$

Returning to the issue of slavery and captives in New France, it should be noted that during the conflict of the 1690s, the Western Wyandot intended to respect an agreement with the League in which both parties would cease the practice of killing individuals captured during raids. Nonetheless, an incident occurred that would test this agreement whereby French 
representatives demanded the killing of some League captives and proceeded to murder a pair of them. When the Wyandot refused to participate, the Ottawa obliged French requests to proceed with the murders of the captives. ${ }^{28}$ Depredations in the frontier wars were not unique to Amerindian society. In contrast to common stereotypes of tribal attitudes toward warfare, earlier in the 1680s three Shawnee captives, (who were eventually adopted by a tribe located on the Gulf of Mexico) were offered the chance by the French to return to their former homes. These captives retorted:

...they were not unnatural enough to abandon their wives and children;... moreover, being in the most fertile, healthy, and peaceful country in the world, they would be devoid of sense to leave it and expose themselves to be tomahawked by the Illinois or burnt by the Iroquois on their way to another where the winter was insufferably cold, the summer without game, and ever in war. ${ }^{29}$

The point here is to quell any confusion over the stereotypes often perpetrated upon native populations. By neither culture nor biology were they predisposed to war at least no more than the European and maybe less in some cases. Regardless, captives and slaves became an institution in the Montreal Union. By 1709, prisoners of war were relegated to slave status and commodities under French law. The giving of captives as gifts became a regular part of FrancoAmerindian diplomacy to augment political and trade relationships. Eventually the gathering of slaves would exceed the boundaries of warfare, and slave raiding would become a self-serving act in itself. The tribal nations of the western Great Lakes, the Great Plains, and upper Mississippi suffered the debilitating effects of slave raids by New France's native allies. The French economy on the St. Lawrence River became enriched, as land owners benefited from a continuous supply of new captives. Upon the capitulation of New France after the Seven Years War, the recently arrived English officials failed in their attempts to build relations with tribal 
nations. The recognition of the slave trade in diplomacy aided the British in developing diplomatic relations among former members of the Montreal Union. ${ }^{30}$

When it was politically expedient and economically viable, the French did ban the practice of the slave trade. For instance, in provincial Louisiana, the slave trade was suspended so that the French could aid in the prevention of the slave raiding being conducted under the banner of the British. Louisiana could easily adopt this policy stance since it had ample access to African slaves. Three thousand plus native peoples were placed in slavery in New France by 1800, and the practice would continue until the end of the War of 1812. The slave population consisted of ethnic Kansa, Chickasaw, Iowa, Sioux, Apache, Quapaw, Osage, and Pawnee to name but a few. ${ }^{31}$

The French/English rivalry spiraled closer to official warfare with the escalation of intense competition over the fur trade. The English were limited in their number of options in expanding their trade networks, as their traders had great difficulty gaining access to the interior. The French ability to control access to the interior was the manner in which they prevented the English from introducing their less expensive, imported manufactured goods into the market. ${ }^{32}$ The English did not control the river systems of the interior, the significance being that rivers literally served as trade highways during colonial times, even as they do today. Nor did the English possess the requisite native allies to gain access to those rivers. Rivers were the most efficient means of orchestrating a trade that was intercontinental in scope. In many ways, rivers were natural extensions of the seas and oceans, and a bridge to the goods of the land. This is why the Ohio River became the initial point of contention between the English and French. 
English gains in the fur trade market were accomplished primarily through the Iroquois Confederacy who controlled the Hudson River access to the Great Lakes. Fur trading was carried out through the Mohawk River and city of Albany. In due course, the Iroquois League would act as trade arbitrators between the English and the interior tribal nations. The introduction of cheap English imports prompted French traders to start an illicit trade with New York by acquiring English products that could be introduced into the interior, providing the French trader with improved profit margins. ${ }^{33}$

The French system of trade served political objectives as well as economic interests. Two basic trade posts were utilized in the French system. Government sponsored posts served the political goal of attaching tribal interests to New France. These posts were highly unprofitable in that the, "Indians and trader, storekeeper and commandment enriched themselves at the expense of the government”. ${ }^{34}$ The other trade post was a leased post in which the leasee gained exclusive trade rights to the operation, which led to local trade monopolies. The cost of the lease also increased the cost of sold goods, which further attracted traders to seek English manufactured goods. The means by which New France protected its near trade monopoly on the interior was a series of forts that stretched from New France down to Louisiana in the Mississippi River Valley.

Entering the 1750s, the French had a clear and centralized two fold strategy to maintain control of the interior. Their policy addressed the threat that the Covenant Chain posed to New France. The French wanted to secure the Ohio River Valley into their defense network. Former Governor Galissoniere saw the Ohio River as a critical strategic point. If this point were to be 
compromised or fall into British influence, a number of possible scenarios could transpose, all to the detriment of the Montreal Union. For example:

1) Increase of British influence with tribal nations of the interior.

2) The Ohio River offered excellent positioning for military campaigns against French strategic forts and trade centers along the Great Lakes, Mississippi and Illinois Rivers.

3) The prevention of successful French military deployments.

4) Spanish Mexico was even considered a possible target for military acquisition if the British were to gain control of the Ohio River. ${ }^{35}$

Through such institutions as gift-giving, the French aimed to prevent those tribal nations existing outside the Montreal Union from entering into a security/trade bloc with the British while maintaining their own regime. The custom of gift giving was deemed by tribal authorities as a lease payment for French habitation and subsistence within Amerindian lands. ${ }^{36}$ Beyond direct aid (giving of gifts,) or beneficial trade, the French also employed religious endeavors such as missions to disseminate their interests. While there were often doubts as to the sincerity of religious conversion, it was a favored method for fragmenting the loyalties of the Iroquois Confederacy. Father Abbe Picquet even went so far as to urge the authorities of Quebec to allow him to lead a mission down the Ohio River as far south as the Cherokee Nation to secure new tribal interests, and to reprimand those tribal polities that would not heed to his voice, or for that matter, the French voice. ${ }^{37}$ The British tried the same methods, but with much less success. These diplomatic schemes were the mechanisms of a "Cold War" between England and France. ${ }^{38}$ Plans to proceed with the increased fortification of Canada corroded in the face of an agricultural crisis that eroded colony food stocks. More so, the leadership of Governor La 
Jonquiere was so riddled with corruption and avarice that it depleted New France's fundamental strategic resources. The "Jobbery, robbery, graft, and hunger disaffected the habitants and led to near revolts in Quebec and Montreal." ${ }^{39}$ In 1752, the situation became so grave that the new temporary governor was unable to dispatch militia units to the Ohio region, because he did not have the necessary logistics to support the operation. Once Marquis Duquesne was appointed to the governorship, he proceeded with his orders to remove the British from the Ohio country. His orders further required him to inform the Amerindian nations of the Ohio that British traders would not be allowed to conduct business in the region. Instead, tribal representatives would have to enter the British colonies to commence commercial activities. By 1753, being unable to gain the voluntary goodwill of the Ohio tribal nations, Duquesne sent 2,000 soldiers into the region to enforce French ambitions. ${ }^{40}$ The French, like the British, could resort to outright coercion when all other overtures failed.

Duquesne enjoyed great but short lived success in the early years of the French Indian War, in large part due to France’s tribal allies or other tribal nations fighting in an independent effort aimed at checking British aspirations. French Captain Dumas projected 2,500 British casualties had occurred by 1756 at the hands of tribal forces. However, by 1759, the British had taken Fort Niagara and the French began abandoning their own forts because they could not supply them. The British Naval blockade starved New France of her ability to wage war. At Fort Duquesne, French soldiers adorned the fort with the heads of Scot Highlanders who had served in the British army, before the French completed the abandonment of their post. ${ }^{41}$ The end of New France occurred in the proximity of Quebec at the Plain of Abraham Battle, where a 
company of "Native Americans and men of mix blood," known as the "Indian Rangers of the Woods," served the victorious General Wolfe. ${ }^{42}$

Before the ink was dry on the 1763 Paris Treaty, French Minister Choiseul began urging the British colonies in North America to rebel and begin an independent nation. France hoped to quell British power with such an event. In time, Benjamin Franklin would parley for 51,000,000 in franc denominated loans, along with accompanying French fleets, soldiers, and aides-decamp, to see the effort through. ${ }^{43}$ The last French governor of Louisiana described the British as "men drunk with success, and who regard themselves as masters of the world" ${ }^{44}$ France would forsake any obligations to her former Amerindian allies. Had the Amerindian citizen of North America been able to extend his credit line beyond the local trading post and into the coffers of the European crowns, then perhaps disease, technology, the slave trade, and religion would not or could not so easily explain or account for the inevitable demise of Amerindian nationalism. Maybe it was not so inevitable, after all. 
${ }^{1}$ Fierst, J. T. (2000). "The Struggle to Defend Indian Authority in the Ohio Valley-Great Lakes Region 1763-1794." Dissertation at the University of Manitoba (Canada) . Ann Arbor, Michigan, USA: UMI.

${ }^{2}$ Rushforth, B. (2003)."Savage Bonds: Indian Slavery and Alliance in New France." Dissertation at the Univeristy of California, Davis . Ann Arbor, Michigan, USA: UMI.

${ }^{3}$ Boucher, C. J. (2001). "The Legacy of Iouskeha and Tawiscaron: The Western Wendat People to 1701." Disseration at the University of Kansas . Ann Arbor, Michigan, USA: UMI.

${ }^{4}$ Fierst, J. T. (2000).

${ }^{5}$ Boucher, C. J. (2001).

${ }^{6}$ Brandao, J. A. (1994). 'Your fyre shall burn no more': Iroquois Policy Towards New France and Her Native Allies to 1701. Dissertation at York Univeristy: North York, Ontario . Ann Arbor, Michigan, USA: UMI.

${ }^{7}$ White, R. (1991). The Middle Ground: Indians, Empires, and Republics in the Great Lakes Region 1650-1815. New York, New York: Cambridge University Press 1991.

${ }^{8}$ Camenzind, K. (2002). "From the Holy Experiment to the Paxton Boys: Violence, Manhood, and Race in Pennsylvania during the Seven Years War." Dissertation at the University of California, San Diego. Ann Arbor, Michigan, USA: UMI.

${ }^{9}$ Graves, William Hilton. "The Evolution of American Indian Policy." Dissertation at Florida State University. Ann Arbor, Michigan: UMI, 1982.

${ }^{10}$ Gitlin, J. L. (2002). "Negotiating the Course of Empire: The French Bourgeois Frontier and the Emergence of Mid-America 1763-1863." Dissertation at Yale University . Ann Arbor, Michigan, USA: UMI.

${ }^{11}$ Graves, William Hilton.

${ }^{12}$ Graves, William Hilton.

${ }^{13}$ Rushforth, B. (2003). Page 31.

${ }^{14}$ Rushforth, B. (2003).

${ }^{15}$ O’Callaghan, E. B., ed. (1853). Documents Relative to the Colonial History of New York; Procured in Holland, England and France by John Romeyn Brodhead, Esq., Vol III. Albany, New York: Weed, Parsons, and Company, Printers. Page 534.

${ }^{16}$ Brandao, J. A. (1994).

${ }^{17}$ White, R. (1991).

${ }^{18}$ Collard, Edgar Andrew. (1976). Montreal: The Days That Are No More. Toronto, Canada: Doubleday Canada Limited. 
${ }^{19}$ Charlevoix, Pierre Francois Xavier de. (1900). History and General Description of New France, Vol 5. Shea, John Gilmary, ed. New York, New York: Francis P. Harper.

${ }^{20}$ Collard, Edgar Andrew. (1976). Page 18.

${ }^{21}$ Brandao, J. A. (1994).

22 O’Callaghan, E. B., ed. (1854). Documents Relative to the Colonial History of New York; Procured in Holland, England and France by John Romeyn Brodhead, Esq., Vol IV. Albany, New York: Weed, Parsons, and Company, Printers. Page 240 \& 241.

${ }^{23}$ Boucher, C. J. (2001).

24 Charlevoix, Pierre Francois Xavier de. (1900). Page 146 \& 147.

25 Charlevoix, Pierre Francois Xavier de. (1900). Page 147.

${ }^{26}$ Collard, Edgar Andrew. (1976).

${ }^{27}$ Collard, Edgar Andrew. (1976).

${ }^{28}$ Boucher, C. J. (2001).

${ }^{29}$ Shea, John Gilmary, ed. (1861). Early Voyages Up and Down the Mississippi by Cavalier, St. Cosme, Le Sueur, Gravier, and Guignas--Munsell's Historical Series No. VIII. Albany, New York: Joel Munsell.

${ }^{30}$ Rushforth, B. (2003)."Savage Bonds: Indian Slavery and Alliance in New France." Dissertation at the Univeristy of California, Davis . Ann Arbor, Michigan, USA: UMI.

${ }^{31}$ Rushforth, B. (2003).

32 Stevens, W. E. (Sep 1916). The Organization of the British Fur Trade 1760-1800. The Mississppi Valley Historical Review, Vol 3 No 2 pp 172-202.

${ }^{33}$ Stevens, W. E. (Sep 1916).

${ }^{34}$ Stevens, W. E. (Sep 1916). Page 177.

${ }^{35}$ Hatheway, G. (1957). "The Neutral Indian Barrier State a Project in British North American Policy 1754-1815.” Dissertation at the University of Minnesota . Ann Arbor, Michigan, USA: UMI.

${ }^{36}$ Macfarlane, P. (1999). Two French Threats to North America 1760-1783 as seen by British Colonial Officials. Dissertation at Concordia University, Montreal, Quebec, Canada.

${ }^{37}$ Hatheway, G. (1957).

${ }^{38}$ Hatheway, G. (1957). Page 21. 
${ }^{39}$ Hatheway, G. (1957). Page 28.

${ }^{40}$ Camenzind, K. (2002).

${ }^{41}$ White, R. (1991).

${ }^{42}$ Bluhm, J. C. (2004). U.S. Army a Complete History. Arlington, Virginia: Hugh Lauter Levin Associates, Inc. Page 46.

${ }^{43}$ Moore, Charles. The Northwest Under Three Flags 1635-1796. New York and London: Harper and Brothers Publishers, 1900.

${ }^{44}$ Quoted in Rea, Robert R. (1990). Major Robert Farmer of Mobile. Tuscaloosa and London: The University of Alabama Press. Page 37. 


\title{
Section III
}

\author{
Chapter 9 - Conclusions
}

\section{5 to the Present-Colonialism, Modernism, Globalism - enter the Post Modern}

From this study of colonial Trans-Appalachia, the evidentiary record of the interplay and formation of three primary security and trade regimes offer a unique opportunity to discuss state development, social organization and democratic theory by drawing from multiple disciplines such as political science and anthropology. At the same time, this case study enriches the dialogue of Postcolonialism and decolonization theory through a historical examination of the high politics associated with the colonial drama of the $18^{\text {th }}$ Century. It would be an error to think of colonialism in too narrow a time frame, in which European kingdoms, nations, and empires were the sole arbitrators of the phenomena. It is critical to also consider an earlier time when much of Europe suffered the intercontinental wars of conquest and colonization by the Romans, the Moors, the Ottoman Empire, and even the Mongols of far Asia, In this respect, issues of colonization and decolonization have affected large segments of humanity.

“Decolonization” in simple terms is nothing more than learning and acknowledging the manner in which the practices of colonization change and shape the outcomes applicable to the social ordering of communities and issues of social justice that necessarily arise thereafter. By the $18^{\text {th }}$ Century, colonization or the domination of societies by other societies reached new 
heights. As stated before, the French and Indian War was a regional, but central, theater of a much broader global war known as the Seven Years War. Colonial warfare in the Modern Age had transcended the scope of a few continents to encompass the entire globe. Due to a legacy of colonization, there remain to this day unresolved issues of social justice in the Americas in which indigenous communities are neither free from external intervention in their community decisionmaking practices nor free from foreign institutional authority that prevents a return to autonomous societies. This legacy has evolved in the context of colonizing regimes. ${ }^{\mathrm{A}}$ The current post-modern discourse is rich and provokes thoughtful consideration of what has passed and what might come to be.

The process of colonization, globalization, and modernization is spoken of by some as a necessary event with both tragic and redeeming qualities. Japanese scholar Francis Fukuyama in the 1990s spoke of this historical era for it is significant because it meant the progress of humanity with implications for a universal human experience that is indicative of a socio-cultural evolutionary process with a beginning and an end that resulted in democratic governments and capitalist economies. This historical evolutionary event was due to the development of Western liberal principles of equality and liberty alongside the development of modern era natural science. He holds that these once held European cultural specific truths now are the property of

\footnotetext{
A This analysis does not examine in detail the role of Amerindian and Spanish regime building in North America. While it could appear there is a northern bias in that the study is weighted toward the events in northern Trans-Appalachia, the geographic disposition of northern Trans-Appalachia seemingly favored more rapid penetration into the interior through the Great Lakes waterways. More so the locality of French Montreal and British Albany due to their close proximity and the disposition of Indigenous nations seems to focus the struggle in this geography. This resulted in a proliferation of commerce and conflict. The French and Indian War was decided in the field campaigns of northern Trans-Appalachia. Later during the 1790s The Early Republic would initiate its invasion of Trans-Appalachia with federal armies by targeting the Ohio Region.
} 
humanity in which Japan serves as the international state standard to "modernization" in Asia rather than the United States. ${ }^{1}$ Fukuyama finds universal validity in the empirical evidence that liberal democracy had conquered alternative and rival ideologies such as communism and fascism in the 20th Century. ${ }^{\mathrm{B}}$ Others have maintained that democracy and capitalism where culturally relevant phenomena with little universal applicability to human society. Regardless, Fukuyama maintains that the universal homogenous state, the historical end product of the modern era is an incomplete victory as peoples still persist in their identities. In this respect, Fukuyama maintains that the international system of states is now an expression of a literal dichotomy between the post-historical age of Western liberalism and the historical where liberal democracy has not taken hold and ideological conflict remains likely. ${ }^{2}$

Yankton Sioux scholar, Vine Deloria in the late 1970s framed the issue a little differently. Deloria in his pursuit to acquire a basis or method for universal interpretation of the world was apprehensive about initiating a diatribe regarding Western Civilization. Yet, he did hold Western Civilization responsible for its choices and by its choices he felt Western Civilization had assumed a global leadership role. He was driven to determine if Western traditions were indeed adequate to fulfill such a role. Deloria noted how western scientists and other professionals were having to increasingly integrate indigenous concepts to advance their technology and intellectual

\footnotetext{
B The criteria to meet the definition of Western liberal democracy are the establishment basic rights to the citizenry of the state and representative government established through regular multi-party elections. Fukuyama also argues the philosophical relevance of the Western Tradition that underlies liberal democracies, e.g. Hegel's dialogue on humanity's desire for recognition that underpins Hegel's master and slave paradigm.
} 
comprehension. His method was a metaphysical approach grounded in empirical evidence and experience. $^{3}$

He contended that when the "seasoned" cognitive synthesis of historical indigenous society could be translated into the provinciality of Western knowledge then perhaps new principles could arise that would "reorient" Western epistemology towards a truly universal synthesis. ${ }^{4}$ In addition Deloria foresaw the possibility that North American indigenous society could participate in, if not lead, the production of a "more sophisticated, humane, and sensible society on this continent" when Amerindians had their own traditional epistemologies reincorporated into the practice of living, in part due to a rigorous intellectual discourse that lead to the social tolerance, acceptance, even maybe conformity of these traditions in contemporary Amerindian society. ${ }^{5}$ Deloria also reported the parallel event between the completion of World War II and the end of the colonial or modern era. In the following decades eighty nations emerged from the collapse of colonial empires in which Europeans transplanted their own models of democracy onto former colonies. He finishes by noting that "only eleven of those democracies survive." 6 \& C

\footnotetext{
${ }^{\mathrm{C}}$ One online source reports that during the 20th Century on an average scale 31\% of humanity lived under a democratic government. [see Historical Atlas of the 20th Century (1998). Democratic Governments 19451995. http://users.erols.com/mwhite28/govt2000.htm. Retrieved February, 2010.] Today the percentage is much greater with the fall of the Warsaw Pact. Significant regions in Africa, the Middle East and Asia remain without having incorporated a democratic form of government. China has a rich society grounded in domestic government traditions developed through Confucianism along with imported traditions. However, China holds reservations and remains skeptical of much of what the West claims. [see Waley-Cohen, Joanna. (1999). The Sextants of Beijing —Global Currents in Chinese History. New York: W.W. Norton \& Company.] I suspect the Middle East runs afoul with Western liberal democracies through their own colonial experiences, along with the problems that ensue with decolonization, and the universal claims of their own religious traditions.
} 
Deloria argued that the experiential fluidity presented by dynamic social activity offered the opportunity for tribal traditionalists to escape "the trap of Western religion, which seeks to freeze history in an unchanging and authoritative past." ${ }^{7}$ He articulated that the future success of traditional religious practices would come not in preserving older forms but in creating new forms that confronted new challenges. ${ }^{8}$ He also figured that traditional Amerindian indigenous spiritual practices were free from a central messianic figure and the dictum associated with such figures. Deloria wondered if the tribe in a general sense would emerge out of the ideological contest of the 20th Century as a "quasi-political entity... an economic structure. Or...become, once again, a religious community." ${ }^{9}$ On a national level Deloria thought Amerindian society had been able to again experiment with intertribal unification for the rest of American society no longer found serious relevance to Amerindian polity. For Deloria, the National Congress of American Indians or the "small united nations of tribes" is the substantial manifestation of an intertribal experiment. $^{10}$

During the 1960s, doctor, decorated World War II veteran, and African revolutionary, Frantz Fanon contributed to Post-Colonial Theory through his critique of both the European colonizer and the colonized of Africa. ${ }^{\mathrm{D}}$ He interpreted overly tribal liberation movements as micronationalisms grounded in specific culture that preempted a national consciousness derived from the practice of decolonization or the ethical practice of emergent third world idealization to

\footnotetext{
${ }^{\mathrm{D}}$ Frantz Fanon was born in the American Caribbean on the Colonial island of French Martinique . He served with Free French Forces and with the French Army in continental Europe. Fanon was awarded a medal of bravery for his participation in the Battle of the Colmar Pocket. Later after his studies in France he developed a model of psychotherapy that integrated culture into the analysis.
} 
promote freedom, integration, security, and economic development. His "tabula rasa" method of achieving this universal man or state was through creating a societal canon developed by experience and perception beginning with the experience and perceptions of the colonizer. ${ }^{11}$ Here the great contradiction originating in Colonial history arises in that the liberal principle of social equality deeply embedded in the psychopathology of racism demands, "the subhuman to rise to the level of Western humanity." ${ }^{12}$

Fanon observed many obstacles to a national consciousness that arose from the syncretism of the intellectual prose of both the colonizer and the colonized. In the colonial tradition of crude and violent syncretism the values of the colonizer were transferred to the colonized in which new and independent African states suffered not from democratic reforms per se but from the embedded elitism of Western liberal democracy which was the hallmark of the so called liberated African "national bourgeoisie" that was central authority operated from the metropolis. ${ }^{13}$ Paternalistic overtones and the syndrome of the dependent exploited whore intercepted the path of a truly national culture.

Fanon also felt that defining a national culture on the basis of race was a "dead end" for too often the race of the colonized was only defined as that which is not white. ${ }^{14}$ In Fanon's analysis, if a dependency complex did indeed exist it came into being through the contact of societies in the context of the colonial vituperative and did not originate in pre-contact aboriginal societies. He further undermines pre-contact dependency status or the sub-human syndrome by revealing Hegel's normative portrayal of the reciprocal master with the reality of the colonial master that indeed was impervious to recognition but desired something altogether different from the slave. ${ }^{15}$ 
This would explain in philosophical terms the failure of sustainable democracy in regions of Africa. I think, Fanon in the experience of the colonized and colonizer reveals fear as a feature of the Colonial persona that they both hold of the other and by the breach of that fear social change could occur.

Fanon, forewarned that Colonialism in Africa was "back on its feet" recovered from early efforts associated with African unity and decolonization. ${ }^{16}$ The re-emergence of colonial practice was occurring through the manufacture of religious rivalries—specifically Christian and Islamic rivalries. ${ }^{17}$ Today in Nigeria the country is caught in the middle of a fierce struggle between Christianity and Islam in which militias, segregation, and vigilantism are typical. Nigeria happens to be the largest African country by population and holds one of the world's largest oil reserves. Its democratic government is riddled with corruption. ${ }^{18}$

In 1776, Adam Smith the father of modern economics wrote in his critique of the Mercantilist international trade system, a Colonial system, that for the Old World to have discovered the trade routes to the Americas along with the East Indies presented the most significant events of the modern era. He thought it was an event with the potential to provide an advantageous international experience as nations would be able promote each other's commerce thus alleviating wants and multiplying the satisfaction of human society. But a much darker experience occurred and Smith wrote:

At the...time when these discoveries were made, the superiority of force happened to be so great on the side of the European, that they were enabled to commit with impunity every sort of injustice in those remote countries...perhaps the natives of those countries may grow stronger, or those of Europe weaker, and the inhabitants...of the world may arrive at that equality of courage and force, by inspiring mutual fear, can alone overawe the injustice of independent nations into some sort of respect for the rights of one another. But nothing seems more likely to establish this 
equality of force than that mutual communication of knowledge and of all sorts of improvements which an extensive commerce from all countries to all countries naturally, or rather necessarily, carries along with it. ${ }^{19}$

Fukuyama fails to address the Colonial context in which Western liberal democracy emerged or rather he mentions it briefly in that Western liberal democracy maybe a cultural phenomena associated with Europe in the modern era and thrived due to its hegemonic qualities. ${ }^{\mathrm{E}}$ However, a number of international states still fulfill the criteria of constitutional monarchies implying rule of law and some level of hereditary influence in government. ${ }^{\mathrm{F}}$ This includes at least nine European countries, the United Kingdom for example, along with Australia, Canada, and Japan. Albeit they have also integrated varying degrees of representative forms of democracy. The democratic republics of the United States, France, Germany, and India seem to be the most prominent models of liberal democracy. Yet, states like Communist China with single political party systems maintain a constitution and hold periodic elections. Secondly, Fukuyama assumes Western liberal democracy was the result of a linear and socio cultural evolutionary historical process as liberal democracy became a secular Christian manifestation. ${ }^{20}$ It may well be but on a longer timeline in which the universalist historian doesn't discard "pre- or

\footnotetext{
${ }^{\mathrm{E}}$ Furthermore in regards to the prospects of Western liberal democracy Fukuyama asserts the primacy of Western liberal democracy with its ideological victory. Yet, this victory didn't occur in an ideological vacuum from a laboratory setting it occurred in the context of politics and a power struggle. There are numerous variables to consider such as the deployment of resources, tactical and strategic implementation, and the articulation or realization of state goals. Or the fact that the Marxist experiment in Russia was not an organic event but rather a violent social intervention by class of despotic ideologues. Was the Lenin regime ever authentically Marxist.

F see Central Intelligence Agency: World Fact Book @ https://www.cia.gov/library/publications/the-worldfactbook/fields/2128.html?countryName=Japan\&countryCode=ja\&regionCode=eas\&\#ja see also The Hawaiian Kingdom-System of Government_Constitutional Monarchies @ http://www.hawaiiankingdom.org/constitutional-monarchies.shtml
} 
non-historical" even so called primitive societies an all together different picture may emerge as a set linear directional process may not correctly explain change in social organization, state features, or the international system. ${ }^{21 \mathrm{G}}$

My point here is not to initiate a tirade on Fukuyama's thesis for I think he is a decolonization theorist of a different cloak and conducts a probing analysis of the issue especially as he directs his dialogue towards realist or real politick international theory which I do not address explicitly in this note. But it is exactly his critique of realist theory that the prehistorical societies of the world cannot be discarded from the analysis. I think Japan in a very genuine manner confronts the socio-political changes forced upon its society with a thoughtful examination and I find Japanese intellectuals sincerely dedicated to international peace. ${ }^{\mathrm{H}}$ Finally, this term pre-historical same as the term primitive is not an adequate descriptor of the world's indigenous populations but rather an elitist and racist misnomer. Lastly, an underlying current of this Post-Modern dialogue is that it is an attempt by several authors who in large part are considering their identities in relation to the rest of the world. In other words they are attempting to center their identities to better understand themselves and their relations.

\section{Synchronic and Diachronic Analysis}

If we develop a synchronic model to analyze social organization with the broad typologies of government and state systems that is not dedicated to an evolutionary bias concerned with beginnings but is rather limited to a comparative context delineated by structural

\footnotetext{
${ }^{\mathrm{G}}$ Discarding relevant data is an attempt by a social scientist to mimic the hard sciences by removing data that doesn't fit their model.

${ }^{\mathrm{H}}$ Nonetheless Japan does have its own history to address with its indigenous Ainu population. see Ainu of Japan @ http://www.ankn.uaf.edu/IEW/ainu.html
} 
limitations to human social organization then we may achieve a more objective and meaningful picture to human relations with the potential to develop a comprehensive theory of human social organization . Structural forms alone cannot explain the outcome of social relations but when the underlying components of government, and state types, (their substantive body) are integrated into the model then we have a basis for comparative study and theoretical propositions. The body of government types and states includes ideological, economic, spiritual, and cultural elements.

The criteria could take on a very uniform approach by adopting Schumaker's, Keil's, and Heilke's criteria for political ideology that include such factors as problems, goals, structure, citizenship, rulers, authority, justice, change, human nature, society, ontology, and epistemology. ${ }^{22}$ Comparative analysis is not limited and can take on an extreme meticulous nature as additional criteria related to society types are integrated into the model from other disciplines of study such as anthropology, psychology, or history, e.g. determinism. Or study could be limited to specific comparisons such as the political economy of state systems. The initial model is an exercise in cataloging the typologies in which base comparisons are significant and can be evaluated in general terms or at specific points in time as such criteria for evaluation maybe customized. So you could examine Monarchy in conceptual terms or examine the French Monarchy in 1776, for example.

Here the criteria are further analyzed to their relationship to heterarchical (HT) and hierarchical (HR) structural forms. These features provide the essential unifying and definitive characteristics to the model. Since neither form is absent elements of the other, except in extreme examples, then one can look to see how heterarchical societies modulate hierarchical expressions 
or the reverse circumstance. In the context of the Colonial or Modern eras the analysis is rich to understand the dynamics between the interaction of society types that differ in this orientation.

Research of this sort may provide a rich empirical base to determine the qualities, processes, and features associated with both concepts.

\section{Synchronic Model of Social Organization (HT) Heterarchical Typology (HR) Hierarchical Typology}

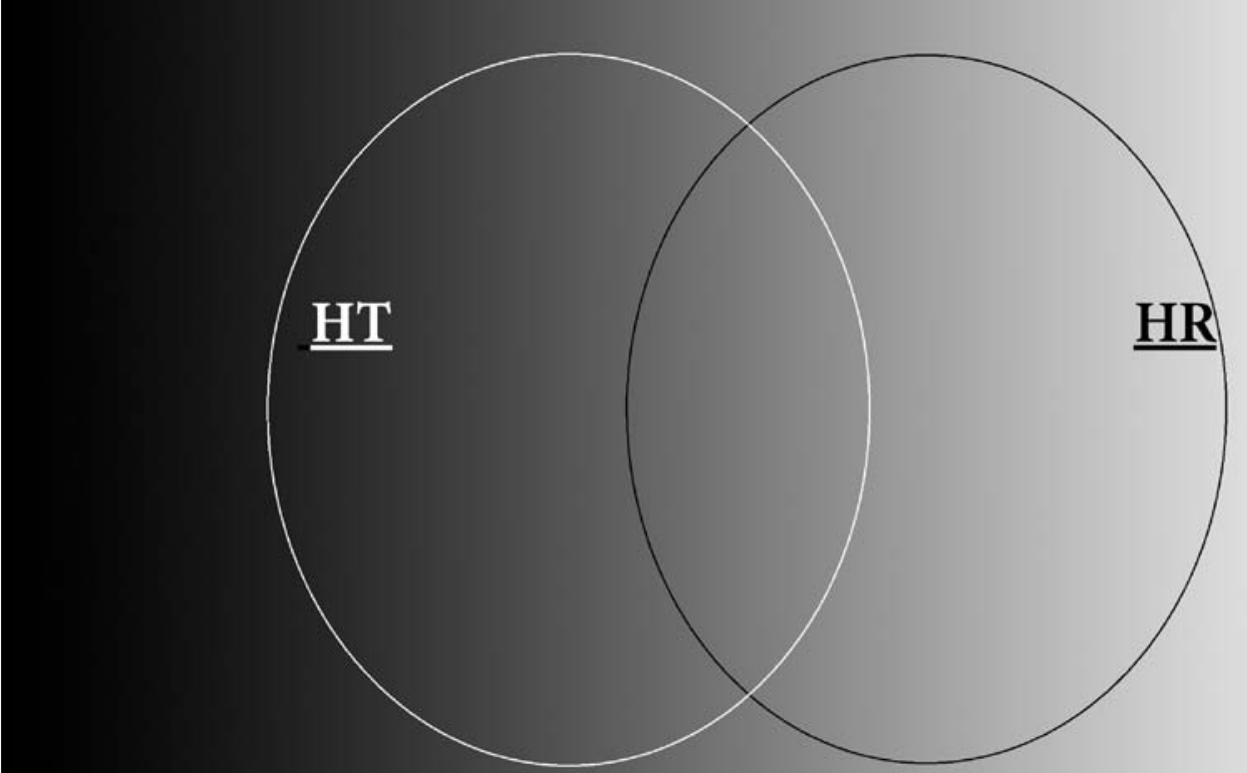


From the synchronic model of social organization we can develop case studies by extracting a given society, or geo-political setting indicative of multiple societal actors and begin a diachronic analysis of social change or development, and test experimental hypothesis. But at this point time I think theory will more like develop as it emerges from the data rather than a rigorous application of the experimental method, but I wouldn't dismiss the experimental method. In a diachronic analysis a timeframe can be established with a beginning and an end to highlight periods of great change and periods that are more static in nature. In the diachronic analysis additional factors would be incorporated such as environmental events/conditions like surplus agricultural production, famine, disease, or natural resource constraints. Another factor for analysis is the condition or interplay of inter-societal contact. Factors like ideology, culture relativism, economics, and spiritual cosmologies or even epistemologies remain relevant by necessity. Further case studies may elaborate on the manner in which heterarchical and hierarchical forms in of themselves become institutionalized or internalized into the other factors or as societal values themselves.

In the following hypothetical illustration the black line represents a society as it changes according to degrees of heterarchical or hierarchical expression through time. Here the peaks (HT) and troughs (HR) of the line indicate social direction towards fluctuating modes of either heterarchy or hierarchy. The arrows represent the types of factors, already mentioned, that influence that change as societies are exposed to them. Admittedly, correlations may be abundant 
and causality may be difficult to prove, but at minimum strong cases can be made from the analysis. The model in itself is not deterministic for human societies make choices and take actions in the face of historical variables which include the resistance to change or take actions that appear irrational or mechanistically logical. How societies adjust to historical factors is pertinent to this research. In the case in which two societies enter into contact then a second line representing the second society could be entered into the illustration. Cross sectional modeling applications is really only limited by the ability of the researcher, or research team to illustrate a comprehensible and functional presentation of the data. The societal line could deviate and split as one society becomes two different societies due to a historical event. These models have implications for both empirical and normative theory. It also provides the opportunity to elaborate on the claims of social and evolutionary psychology as both are concerned with aggression and cooperation .

The historical factor can even be directed toward such events as governmental policy or resolutions, e.g. decision making. For example the Royal Proclamation of 1763 was a policy developed in the context of a ranked hierarchical society. Here the English Crown represents the highest rank of executive authority, or the King's prerogative, in British political order. The policy was developed through inputs provided by lower ranked subordinate agents of the Crown in the American colonies. This policy was also developed in consideration of British economic mercantile goals. The middle rank of authority in this policy process was the King's cabinet or

\footnotetext{
${ }^{\text {I }}$ Heterarchy as a concept was originally used in brain research in the 1940s, since then it has been used to develop theory in mathematics, sociology, archaeology, anthropology, artificial intelligence, computer applications, ecology, and operates in a broader framework of Complexity Theory. (Crumley, 2005)
} 
ministers and their secretaries. The policy did not consider inputs from either Amerindian society or from the colonial governments in its conception. On the ground floor of its implementation agreements over its implications were conducted by Crown agents and the authority of Amerindian decision makers in an open consensus like dialogue, that precluded broad input from colonial governments. Here the authority of the Crown failed to affect desired outcomes with its stated policy goals. The later Quebec Act which effectually replaced the Royal Proclamation of 1763 considered inputs from French Canadians and was an act of British Parliament (a cohierarchical structure to executive authority?) rather than the Crown but it also failed. Seemingly, the decision making structure of England seemed to lack either the coercive or moral capacity to initiate successful policy. Would a consensus driven solution have affected the colonies to consider other alternatives to unbridled expansion. I think the evidence suggest it would have not, but maybe.

On the other hand, the Great Peace of Montreal of 1701 was a consensus driven policy initially a course set upon by peace overtures between the Iroquois League and the government of New France. The negotiations were conducted over a two year period. As stated earlier the negotiations included over 40 Amerindian nations and New France. By evidence of the signatories of the document the polycentric and diverse nature of the delegates reveals that an obvious heterarchical process occurred. Amerindian signatories included martial and civil chiefs along with ambassadors who were endowed with a temporary authority to act on the process. Amerindian signatories were significant for representation of their nations, villages, clans, and individual authority. ${ }^{23}$ 
While this agreement recognized the political autonomy of its participants its ability to follow through with its stated goals was undermined by the fact that English representatives were not directly involved. It was further undermined by the fact that the French participated in the event with a covert agenda as the French Crown during these negotiations had directed New France to adopt a policy of containment, more specifically the containment of English expansion. For New France the Great Peace of Montreal neutralized the aggression of the Iroquois League and preserved the Franco-Amerindian alliance. ${ }^{24}$ Other factors to consider is that the negotiations at least in the final document don't reflect a comprehensive dialogue on trade and it should have since trade was central to the martial aggression of the previous decades. The Montreal Peace like the Franco-Amerindian alliance (Montreal Union) was heterarchical in its process but hidden hierarchies also impacted the policy through covert agendas operating under the authority of the French Monarch. New France's government was limited in its ability to participate or coordinate meaningful inter-societal dialogue.

This study of regime formation and state seeking behavior observed in the inter-societal conflicts of Colonial Trans-Appalachia that I refer to as the Proclamation Wars is a diachronic analysis. What emerged from the analysis was two different models of democracy grounded in two different modes of social organization. The subsequent dialogue will continue to examine this phenomena hopefully providing a basis for peoples to better understand their own societies and the contemporary issues that arise from a clash of civilizations. 


\section{Diachronic Model of ocial Organization}

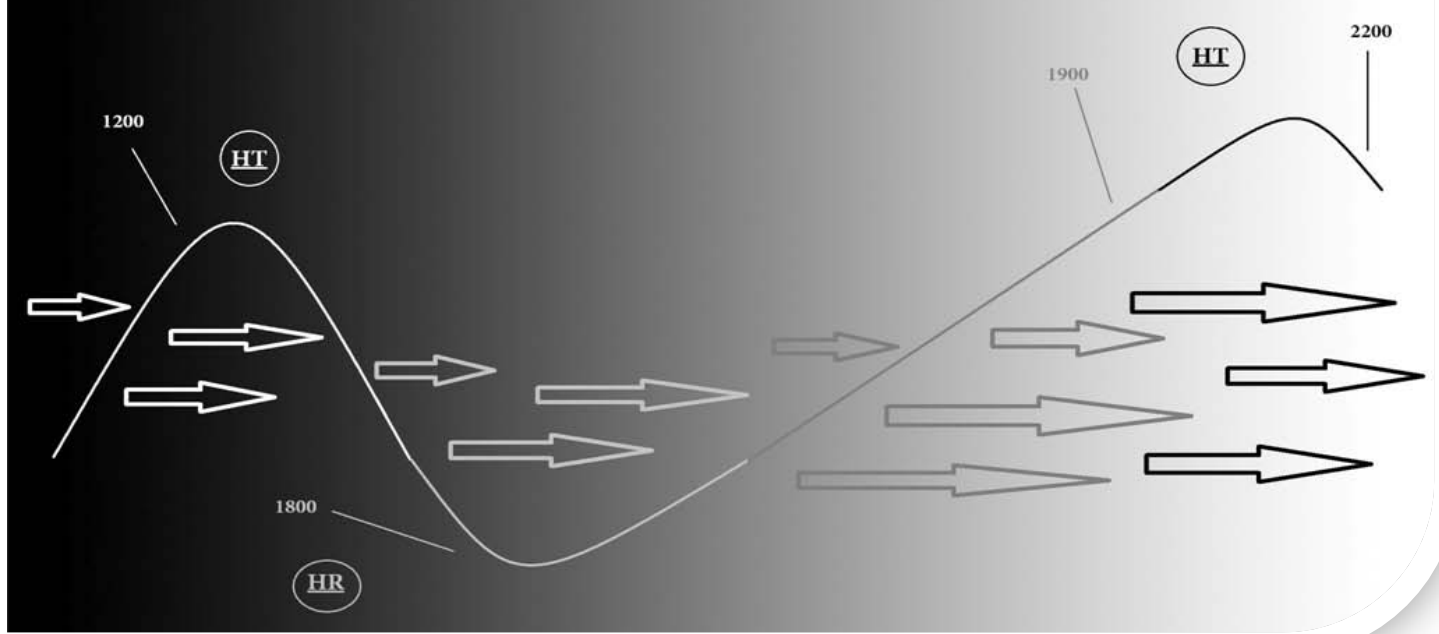

\section{Models of Democracy}

State development is often explained in a model of social evolution grounded in increasing stages of the centralization of authority expressed through structures significant for degree or ranks of hierarchy. ${ }^{25}$ From this perspective, the pre-state model of a chiefdom is considered to be a preexisting condition to a given state society. ${ }^{\mathrm{J}}$ A centralized chiefdom model lacks but is presumed to have the potential to develop the institutional structures that eventually

\footnotetext{
${ }^{\mathrm{J}}$ A chiefdom is originates when an individual leader controls or governs more than one village, town, or population center with clear top/down authority.
} 
characterize state level organizations. However, the chiefdom model of organization does not become apparent in this study until the latter end of the time frame when the forces of colonialism and the successful intervention of European agency into Amerindian nations resulted in more centralized, hierarchical authority structures within Amerindian polities.

On a broad scale, the regimes of Trans-Appalachia in their interaction and origin reveal a dialectic between heterarchically-oriented Amerindian societies and hierarchically-oriented European societies. This dialectic suggests a specific model of colonization, state development, and democratic theory. Amerindian society of Trans-Appalachia appears to have been organized around principles of heterarchy in which both intra- and intertribal authority was dispersed and decentralized through different segments of society. These would have included ceremonial, clan, civil, familial, economic, and martial elements that incorporated similar cultural value systems and/or ideological underpinnings. Within these arrangements and associations, the need for the institutionalization or reinstitutionalization of social elements was a necessity for severe political decomposition was becoming rampant within Amerindian polity.

The authority of the person as leader and the position held did not imply a formal exercise of coercive authority that was acknowledged by all social segments. The Amerindian decision maker was generally limited by consensus-driven decision making. At the level of community-building consensus, Amerindian social organization was affected by broad community inputs that resulted in leveling effects on leadership. In this respect, decision making was conditioned by commitment to consensus based leadership. It was manifest in a cooperative ethic that mitigated intra- and inter societal dilemmas. At a minimum, this style of leadership 
also provided for an ethic of non-interference. The issue of social complexity is relevant for interpreting inclusive decision making standards. It requires extensive dialectical processes that must accommodate complicated variables of specific human personae in the context of their social responsibilities.

This is not to say that coercion was absent in this sort of decision making, but that it occurred in specific contexts as a result of collective decision making such as a consensus in council, ritual consideration, or the act of a point person. I suspect this kind of decision making, with its inclusive dialogue aimed at achieving public policy accords through comprehensive consensus standards, tended to reduce conflict to occurrences that are low in intensity and short in duration. Stevens, "Most distasteful to the Indians was the coercive nature of white society..."${ }^{26}$ He highlights that Amerindian society relied upon persuasion and social sanctions to maintain social stability. ${ }^{27}$ So I suspect that even when coercive application was employed it generally acted upon the individual or group in a compelling manner rather than in a hegemonic fashion. Stevens records missionary David Zeisberger's comments, "They admit that the whites are very ingenious...but regard their manner of living as wearisome and slavish..."28

To say the least Amerindian society valued individual liberty, highly. On Amerindian reverence for equality one must only observe the practice of incorporating Euro-Americans into Amerindian society through captive taking, adoption, marriage and so on. Historical captive narratives relate the manner in which Euro-Americans were given the same treatment as any other citizen of the community regardless of their sex or skin color. Most adoptees in Amerindian society were women and children. Often peace settlements included terms, 
demanded by English authorities, to return adoptees even the children of adoptees who were born in tribal communities. Some adoptees returned to their tribal communities on their own accords after such peace settlements. Captive narratives also related the just and moral character of tribal communities to the discontent of their colonial counterparts. ${ }^{29}$

In contrast European colonial societies that operated in and around the periphery of Trans-Appalachia are noted for hierarchical decision making structures grounded in formal offices, titles, and rights established through an institutionalized legal system. Even at the most rudimentary level, as early European legal systems often were, these had to consider the inconsistent and extra political measures promulgated by kings. Kingship provided permanent coercive authority to the office holder within the given definitions of the office. European colonial societies operating in the Americas were dependent upon a higher overseas authority that ultimately derived from a hereditary monarchy. Even where democratic structures were present, such as in the legislative assemblies of the English colonies, or the developing British parliament, their objective was not comprehensive consensus making but rather a simple majority consensus within which citizens held very asymmetrical rights. These were reflected in their ability or in ability to participate in their own self-governance. Furthermore, the location of governing structures in colonial systems relative to other governing structures reflected a series of competing hierarchies rather than a series of cooperative heterarchical structures. This was the case in the later days of Colonial Trans-Appalachia with the emergence of U.S. federalism.

Whether governing structures reflect a heterarchical organization or a hierarchical organization is appropriately measured in any given system's approach to consensus building. In 
the European democratic movements of North America and Europe, there was a focus on different social agents such as landholders. Ultimately, the individual citizen whether commoner or social elite sought to acquire a portion of the monarch's sovereign authority. Social relations were ultimately defined in this manner. The monarch’s authority was dispersed throughout a society in which different elements could use their new sovereign authority to exploit other elements of society through overlapping legal, legislative, and executive structures. These operated on local, regional, and national levels. In this scenario, zero-sum social outcomes are probable, if not likely. If these democracies had not developed from a backdrop of monarchies, they may have developed differently or along other lines. Despite constitutional enumeration the current status of states, may be more indicative of administrative regions that were tied to a centralized authority than entities that enjoyed great political autonomy.

Anglo-Saxon democratic traditions in part developed because of the British Crown's struggle with its own advisory councils that later became the British Parliament, a bicameral legislature. Government sanctioned events like the Magna Carta, the Petition of Rights of 1628, The Charter of Henry 1st, and the Bill of Rights of 1689 established the rule of law, an elected legislature, and executive office. Yet the legislative and executive branches of British government to this day retains significant hereditary components. ${ }^{\mathrm{K}}$ While the United States broke from this hereditary dimension a great deal of the United States government is structured in a similar fashion with its own roots in these same documents. This is not to say that American

\footnotetext{
k see Britannia History @ http://www.britannia.com/history/docs/index.html see also Welcome to the United Kingdom Parliament @ http://www.parliament.uk/
} 
democracy was not influenced or inspired by generations of contact with Amerindian society. I do think the conceptual individualism of Euro-American society is linked to the consummate individual of Amerindian society who could emerge and handle all sorts of roles required by his society at any given moment. From this background the United States has attempted to socially address the principles of liberty and equality. Initially only white landowners had the right to vote. Since then equality and liberty have been expanded through the Women's Suffrage Movement and the Civil Rights Movement.

In the context of the sovereign's repeating and ranked hierarchies, social elements were not required to develop a comprehensive consensus to achieve their agenda. Rather, they had multiple offices and other avenues along which they could pursue their goals. This was an especially rich “gaming” environment for social elites. Today, we tend to discuss democratic governments as to which party is currently holding power. We should also ask which lobbyists hold power and what power hierarchies they represent. In this system, the nature of an office is vulnerable or open to agendas they were not designed to serve. The strategy of the office is to expand its authority within the system leading to intra-societal if not inter-societal conflict. The nexus between wealth and democracy in this model is the ability of individuals or groups to seize upon vulnerabilities to increase social and economic standing while upholding the veneer of uncompromised democratic processes. Further potential competitors to such groups are locked out through the coercive authority of institutionalized hierarchies. 
Adam Smith, forewarned of this dilemma or the dilemma of the shopkeeper lobbyist even though he was applying it to the British government's empire building in the Americas it has contemporary and historical relevance to U.S. government. Smith wrote:

Too found a great empire for the sole purpose of raising up a people of customers, may at first appear fit only for a nation of shopkeepers. It is, however, a project altogether unfit for a nation of shopkeepers; but extremely fit for a nation whose government is influenced by shopkeepers. Such statesmen, and such statesmen only, are capable of fancying that they will find some advantage in employing the blood and treasure of their fellow citizens, to found and maintain such an empire. ${ }^{30}$

This analysis of Amerindian society and Euro-American society suggest two different models of democracy. I do not think Amerindian society of Trans-Appalachia was without any hierarchy nor do I think the development of European colonial democracies were without a total absence of heterarchy. Rather, the issue is one of degree. At last, the spiritual cosmologies of these two systems provide even greater insight into their differences and structures. The definitive feature of European monarchs were their divine right kings. Kings who were subject to no earthly authority but only to the authority or will of God. In other words divine right kings were second only to the ultimate sovereign and his kingdom. So whether the European was prone and prostate in worship before their paternalistic king or prone and prostrate in worship before their fatherly God they were in practice submitting their will, conscious, and being to a higher authority. Liberal democracy as discussed by Fukuyama is tied up in all sorts of overlapping and meandering hierarchies that deeply permeate the individual persona.

On the other hand Amerindian spirituality is differentiated through the practice of communion with the earth, and to some extent the cosmos in which a meaningful respect and appreciation for life developed. In this context the pre-contact Amerindian citizen was a self- 
regulating moral agent who did not raise her/himself over other beings in creation who tried to resolve social conflict through consensual standards of conduct rather than through the permanence of institutionalized coercive authority. Normatively, I propose that the universal nature of man/women will emerge with a mature and more clearly defined character as consensus based social interactions are recovered from antiquity. Universal man/woman will be born from the experience and practice of consensus driven relations rather than from lofty philosophical explanations. The consensus standard of relations becomes an epistemology in of itself as man potentially discovers man in which a universal ontology of man comes into being. Now whether consensus based social standards can be reincorporated into the post-modern world is all together another question that I choose not to address here.

\section{A Model of Colonialism and State Formation}

A number of issues arise in the formation and tenure of colonial regimes. Their formation is linked to the emergence of trade relationships. Two expansionary regimes developed known as the Montreal Union and the Covenant Chain. The regimes were expansionary in that they attempted to increase the scale of trade through territorial claims, the incorporation of new members, and the ruin of actual or potential trade competitors. Trade introduced hegemonic forces into tribal polities. In the case of the Covenant Chain, the regime also used land annexation practices for the purpose of resettling Amerindian populations while opening lands for colonial immigration. Over time, the nature of these regimes moved beyond the tenets of mere trade and developed political dimensions with considerations for security and territorial authority. These themes were consistent with the high politics that resulted in the French and 
Indian War. The formation and expansion of these regimes introduced a period of high-intensity conflict over a prolonged period of time. In the years preceding the French and Indian War, there was an increasing impulse by Europeans to expand further into the Trans-Appalachia Interior in order to incorporate new members and expand territorial dominions. The response to this was an Amerindian regime that formed for the purpose of resisting territorial expansion into the interior. The various regimes laid an authoritative claim to their respective spheres of influence consistent with the basic requirements of a state society. Those requirements included geographic borders, domestic political authority, and the recognition of other states in their roles as actors.

The era of the French and Indian War is also significant for the number of ways in which Amerindian political culture was altered, especially with respect to consensus traditions. This occurred on two tiers and in various forms. On one level, Amerindian individuals or groups who controlled trade became less inclined toward consensus building solutions. They manipulated their trade status to affect public outcomes in a unilateral fashion to which Europeans had little input. Europeans had to contend with Amerindian polities that exercised greater political agency. The nature of Amerindian warfare changed to reflect currents of trade. Over time, the escalation of European agency was accompanied by more frequent contact with a larger number of Amerindian nations. These favored regime formation. Fewer Amerindian trade polities could no longer enforce or define the terms of trade without the cooperation of European counterparts. European agency could manipulate debt factors and trade benefits to exploit Amerindian rivalries (or create rivalries that did not exist) through the continuation of intertribal warfare and eventually intratribal warfare. Within the Covenant Chain, colonial authorities appeared to work 
with a duel agenda in which: 1) trade was pursued with Amerindian society while 2) colonial authorities simultaneously sought to alter Amerindian culture and society for the benefit of European expansion. This was less clear among the member nations of the Montreal Union.

Alteration of Amerindian social norms posed challenges to consensus governance. Colonial authorities, especially English authorities, routinely demanded Amerindian acculturation to English standards and practices of inter-societal decision making and negotiation. Colonial authorities attempted to procure and even endorse individuals from Amerindian societies that could enforce unilateral agreements within their respective tribal nations. They did so without regard for establishing a community consensus. Amerindian female roles were severely curtailed, as were those of other leaders. In this interplay between English colonial authorities and Amerindian society, hierarchical command structures gradually and increasingly altered Amerindian decision making structures through specific Amerindian individuals who exercised roles in this process. The introduction of European-style hierarchical authority to Amerindian society intensified as Amerindian nations’ loss of trade parity affected tribal authorities. These began relying more on annuity and gift payments as a source of authority to affect public policy. So, too, did the roles of traders, missionaries, and political authorities such as Indian agents, all of whom were pivotal players in this process.

There were various responses to European demand for Amerindian leaders who could act—in a fashion mirroring their own leadership—-with unilateral impunity. I think this led to a misinterpretation of statements or claims made by certain Amerindian leaders. At different times they made public statements to the effect that they were indeed the essential figures representing 
Amerindian interests. These must be considered in light of the political dynamics that resulted in such statements. In many cases, these leaders simply were trying to assert that a consensus had been sought and established without co-opting the actual authority that resided in a larger group. A number of Amerindian polities began to establish a nativist cross-national consensuses that attempted to mitigate incursions into Amerindian social polities in order to check colonial efforts at western expansion. Early manifestations of this nativist movement can be traced to tribal leaders in the Ohio River Valley associated with such Amerindian nations as the Shawnee or Delaware and in southern Trans-Appalachia with the Creek leader, The Mortar. The prominent issue driven by Ohio Amerindian authorities at the Easton negotiations during the French and Indian War was land tenure issues, corruption in land transactions, and a stop line in which settlements would not occur beyond. After the collapse of the Montreal Union at the close of the French and Indian War a new war shortly ensued commonly associated with Pontiac. At one level, the initiation of war on behalf of Amerindian nations reflected a general consensus at checking British authority and disseminating the terms of land tenure. On another level, Amerindian nations had varying reasons for their participation. Former members of the Montreal Union to some degree wanted to restore the French to their former position while other participants in the war sought to establish a larger corporate nativist polity. They wanted this whether or not the French would return with any importance. In southern Trans-Appalachia, the equivalent to Pontiac's war occurred during the French and Indian War as the Cherokee became disillusioned with their British ally. The Creek successfully maintained a non-alignment posture 
during the war while the Chickasaw maintained their relations with the British. The Choctaw recovered from an internal civil war initiated over an issue of European trading partners.

Attempts to establish an intertribal nativist consensuses that spanned geographic TransAppalachia resulted in polities with clear goals but not polities that were successful at securing the support and favor of all segments of Amerindian society. The former trade wars and competing Amerindian and European regimes weighed heavily in this matter. These goals included an end to intertribal warfare, trade reform, the establishment of permanent borders between Amerindian and colonial societies. The one demand placed upon Colonial authorities by this nativist regime was a requirement that land tenure issues between Amerindian society and colonial society could only legitimately be arranged through a unanimous agreement that took into consideration all the Amerindian nations involved. Authorities of the United States never acknowledged this consensus.

This nativist polity remained an effective regime for six decades. Its status remained intact to varying degrees until the end of the War of 1812. This regime cannot be mistaken as an empire in work, for its leaders and members did not use martial authority to gain new members. Instead, they relied upon consensus building traditions in open councils to incorporate new membership who shared similar concerns and values. This regime was an attempt at state making on a level that would be recognized by other international actors. The key issues were land tenure and the retention of Amerindian political autonomy. The nativist regime maintained a primarily defensive war to achieve this recognition. It did not entertain a scheme that involved the conquest of European colonies already in existence. 
Trans-Appalachia during this era is unique because it lacked state actors at as we typically think of them. If they had been treated by the Europeans as equals, the Montreal Union and the Covenant Chain regimes may have eventually developed into state entities that incorporated both an Amerindian and European citizenship. Of course, the Montreal Union development ended with the French and Indian War. The Covenant Chain Regime didn’t survive the American Revolution. The states that did develop were the United States (British Colonies) and Canada.

Amerindian society that remained within the dominion of the United States after a martial conquest was integrated into the pan-tribal governing structure known as the Bureau of Indian Affairs (BIA). The BIA is typical of a hierarchical regulatory structure that can operate with unilateral authority within the confines of its enumerated powers. The BIA was originally a subordinate agency under the Department of War and it now administered under the direction of the Department of the Interior. Normatively, the BIA should not have existed at all for the Department of State was the, or is the proper federal agency to address relations significant for treaty processes between distinct and separate political agents. Yet a case can be made that the terms of the treaties altered this relationship.

It seems likely that today a number of non-status Amerindian polities choose not to seek recognition from the federal government as a means to passively resist additional exposure to hierarchical authoritative structures that they perceive as detrimental to their traditional (and 
successful) indigenous forms of social organization. ${ }^{\mathrm{L}}$ Further many groups are well aware of the extra-political dimensions of the federal recognition process. The BIA is just as much a political tool for covert agendas as any other regulatory agency vulnerable to party politics and the private interest of lobby groups, including federally recognized tribes with ties to corporate capital. In this respect the federal recognition process is a political means to discredit non-status Amerindian polities. That's right, Amerindian casinos have reintroduced the old trade paradigm of the Colonial era back into the equation. If the United States Congress can't reach a conscionable consensus, even a simple majority consensus as it is entranced by the agendas of lobby organizations then how likely is an intertribal consensus going to develop now that federal tribal polities are tied to the same sorts of organizations through their partnerships with corporations in the tribal Casino industry. Deloria wrote that there were real national issues at stake that required a unified consensus but that the politics of Amerindian unity preclude this accomplishment. When Deloria was with the National Congress of American Indians a white colleague of his informed Deliria that he should speak for those Amerindian nations he represented and no more. Deloria thought to publically state at the next NCAI meeting but didn't that he, "...represented 107 of 315 tribes, so I could be trusted 107/315 of the time. And that the building was on fire." ${ }^{31}$

Ending with a speculative dialogue, what does become apparent in the wars of the Colonial era and even now is that a western view of property rights hold a central place in the scheme of geo-political events whether purposefully by design or by default of the victor. Other

\footnotetext{
${ }^{\mathrm{L}}$ Spiritual orientations for some groups have a prominent role in this decision.
} 
views or systems of property rights have not survived. At the end of the Cold War with the Reagan Administration's decision to finance public spending and increase the military budget successfully broke up the Warsaw Pact. This event brought with it a fundamental change in property rights for much of the known world leading us to a more global unified trade system. Maybe the more current Middle East conflicts have less to do with oil and terrorism as it does with property rights and the completion of a global trade system based on the rights of property holders in a western context. Global trade has increased and capital is can now cross more borders with less risk but at what cost? Could we have not developed a global trade standard through consensus and sanctions? The United States has yet to manage its perpetuity to finance public spending since the onset of the Cold War as has most of the countries of the western world. The European peasant is no longer to tied to the land but to the production and consumption cycle of corporate capital or the public welfare of the state. 
${ }^{1}$ Fukuyama, Francis. (2006). The End of History and the Last Man. New York. Free Press. Page 243.

${ }^{2}$ Fukuyama, Francis. (2006).

${ }^{3}$ Deloria, Vine. (1979). The Metaphysics of Modern Existence. San Francisco: Harper \& Row.

${ }^{4}$ Deloria, Vine. (1978). Civilization and Isolation. University of Northern Iowa. The North American Review. Vol 263 No 2 pp 11-14. Page 14.

${ }^{5}$ Deloria, Vine. (1978). Page 14.

${ }^{6}$ Deloria, Vine. (1979). Page 3.

${ }^{7}$ Deloria, Vine. (1999). For This Land Writing on Religion in America. New York: Routledge. Page 42.

${ }^{8}$ Deloria, Vine. (1999).

${ }^{9}$ Deloria, Vine. (1999). Page 43.

${ }^{10}$ Deloria, Vine. (1988). Custer Died for Your Sins An Indian Manifesto. Norman, Oklahoma: University of Oklahoma Press. Page 219.

${ }^{11}$ Fanon, Frantz. (1961). The Wretched of the Earth. New York: Grove Press. Page 1.

${ }^{12}$ Fanon, Frantz. (1961). Page 110.

${ }^{13}$ Fanon, Frantz. (1961). Page 101.

${ }^{14}$ Fanon, Frantz. (1961). Page 152.

${ }^{15}$ Fanon, Frantz. (1967). Black Skin White Masks Translated by Charles Lam Markmann. New York: Grove Press, Inc.

${ }^{16}$ Fanon, Frantz. (1961). Page 107.

${ }^{17}$ Fanon, Frantz. (1961).

${ }^{18}$ Griswold, Eliza. (2008). God's Country. The Atlantic. http://www.theatlantic.com/doc/200803/nigeria. Retrieved February, 2010.

${ }^{19}$ Smith, Adam. (2003). The Wealth of Nations Introduction by Alan B. Krueger. New York: Bantam Dell. Page 794.

${ }^{20}$ Fukuyama, Francis. (2006).

${ }^{21}$ Fukuyama, Francis. (2006). Page 139. 
${ }^{22}$ Paul Schumaker, Dwight Kiel, and Thomas Heilke. (1996). Great Ideas/Grand Schemes Political Ideologies in the Nineteenth and Twentieth Centuries. New York: The McGraw-Hill Companies, Inc.

${ }^{23}$ Havard, Gilles. (2001). The Great Peace of Montreal. Montreal: McGill-Queen's University Press.

${ }^{24}$ Havard, Gilles. (2001).

${ }^{25}$ Hoopes, John W. (March 2005). "The Emergence of Social Complexity in the Chibchan World of Southern Central America and Northern Columbia, Ad 300-600." Journal of Archaeological Research. Vol 13 No 1 pp 1-47.

${ }^{26}$ Stevens, Paul Lawrence. (1984). His Majesty's "Savage" Allies: British Policy and the Northern Indians during the Revolutionary War: The Carleton Years, 1774-1778. Dissertation at State University of New York at Buffalo. Page 29.

${ }^{27}$ Stevens, Paul Lawrence. (1984).

${ }^{28}$ Stevens, Paul Lawrence. (1984). Page 29.

${ }^{29}$ Axtell, James. (1993). The White Indians of Colonial America. Major Problems in American History Documents and Essays. Kupperman, Karen Ordahl, editor. Lexington, Massachusetts: D.C. Heath and Company.

${ }^{30}$ Smith, Adam. (2003). Page 780.

${ }^{31}$ Deloria, Vine. (1988). Pages 212 \& 213. 


\section{Appendix: Maps and Key to Maps}

Map 1) Amerindian Sphere of Influence

-White Diamonds indicate Amerindian population centers at the time of the French and Indian War. Population centers in some cases are indicative of multi-ethnic tribal populations.

Map 2) British Sphere of Influence

- Red Circles indicate British forts, cities, and/or diplomatic centers at the time of the French and Indian War.

Map 3) French Sphere of Influence

-Blue Circles indicate French forts, cities, and/or diplomatic centers at the time of the French and Indian War.

Map 4) Royal Proclamation of 1763

-White Line indicates the extent of the border created by the Royal Proclamation of 1763.

-Blue Lines indicate the breadth of the Mississippi, Ohio, and Tennessee Rivers.

- Green Circles indicate Spanish controlled cities at the onset of the French and Indian War.

- Red Circles indicate British controlled cities at the onset of the French and Indian War.

-Blue Circles indicate French controlled cities at the onset of the French and Indian War. 
Amerindian Sphere of Influence

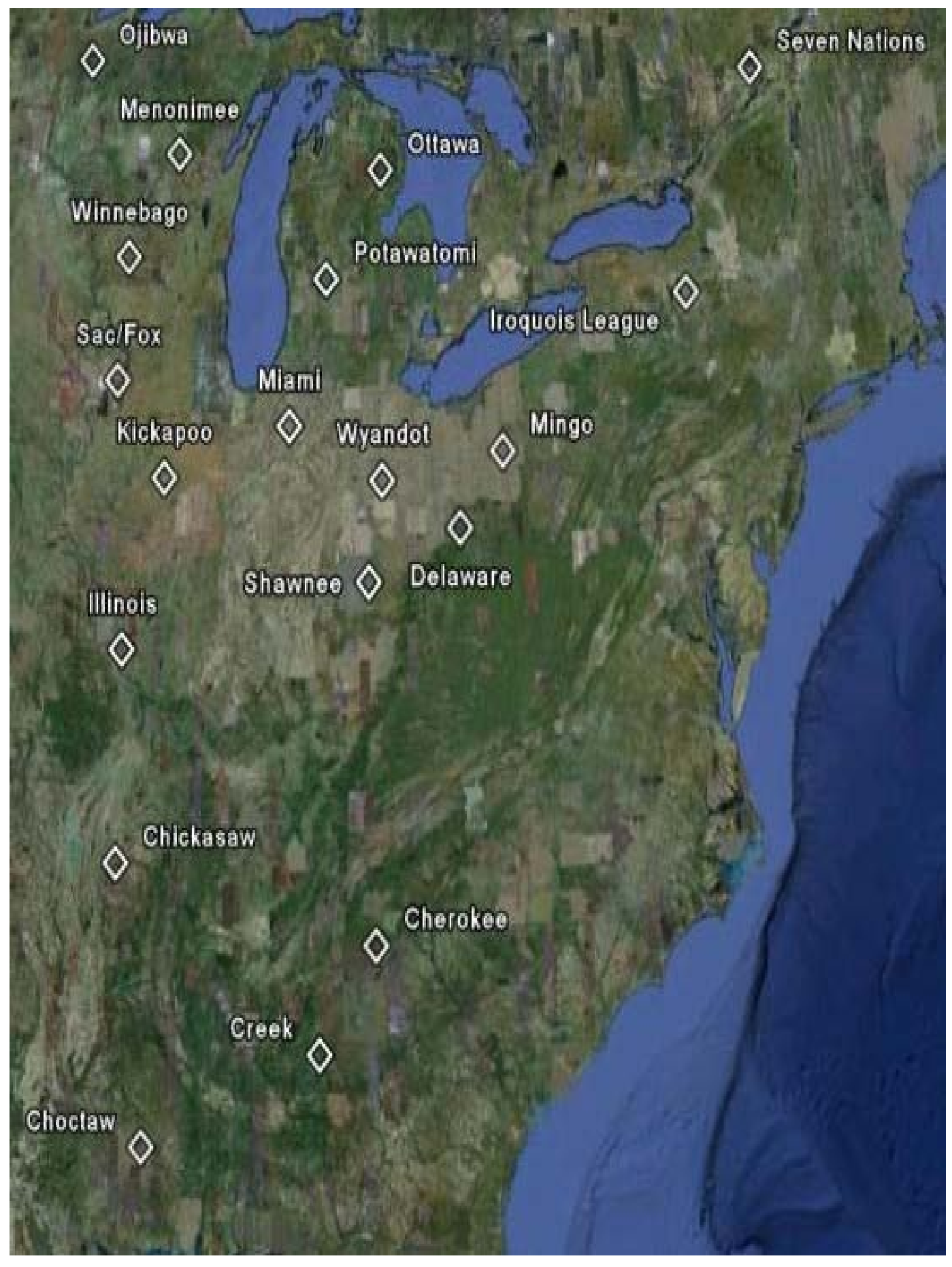


British Sphere of Influence

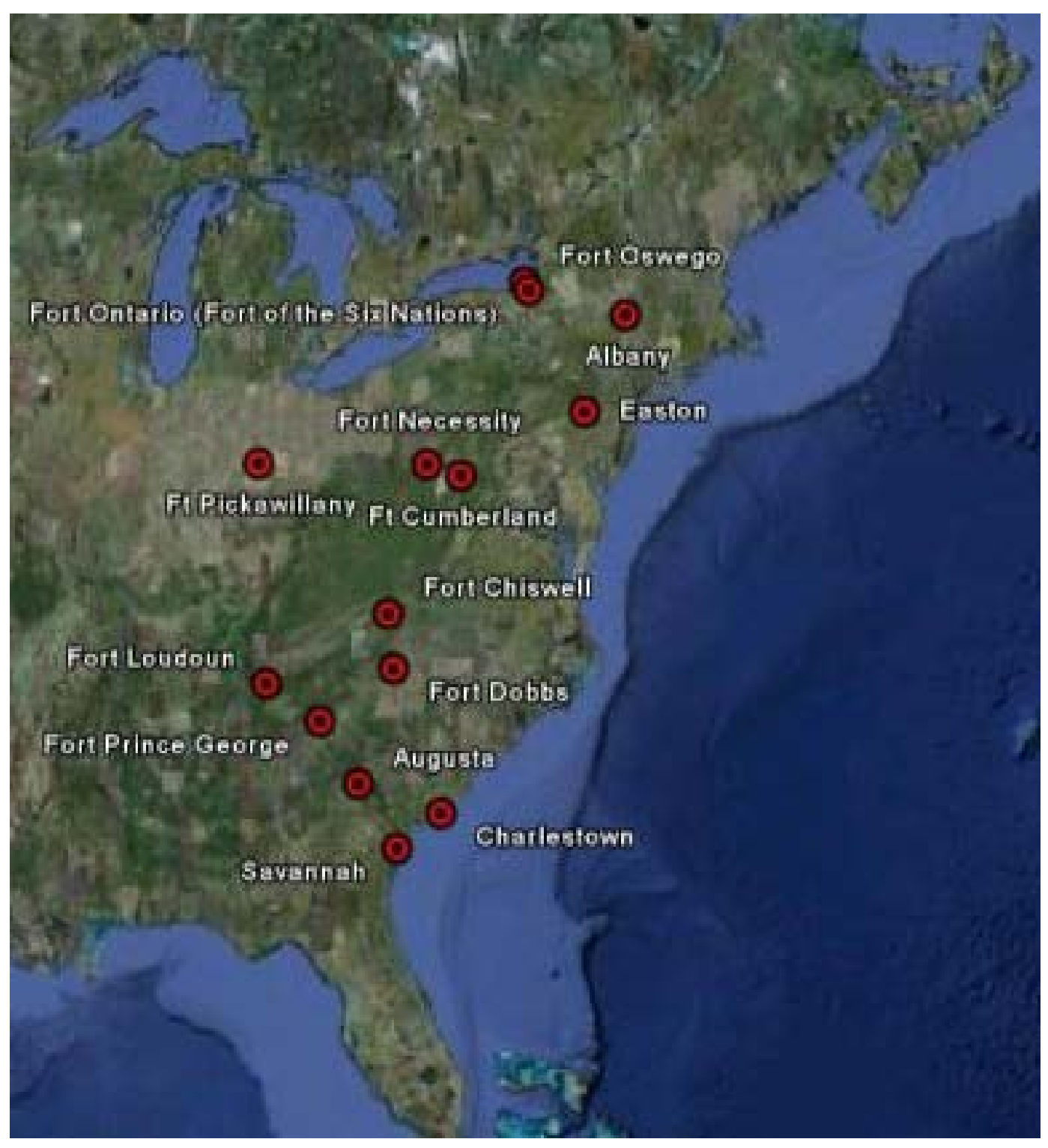


French Sphere of Influence

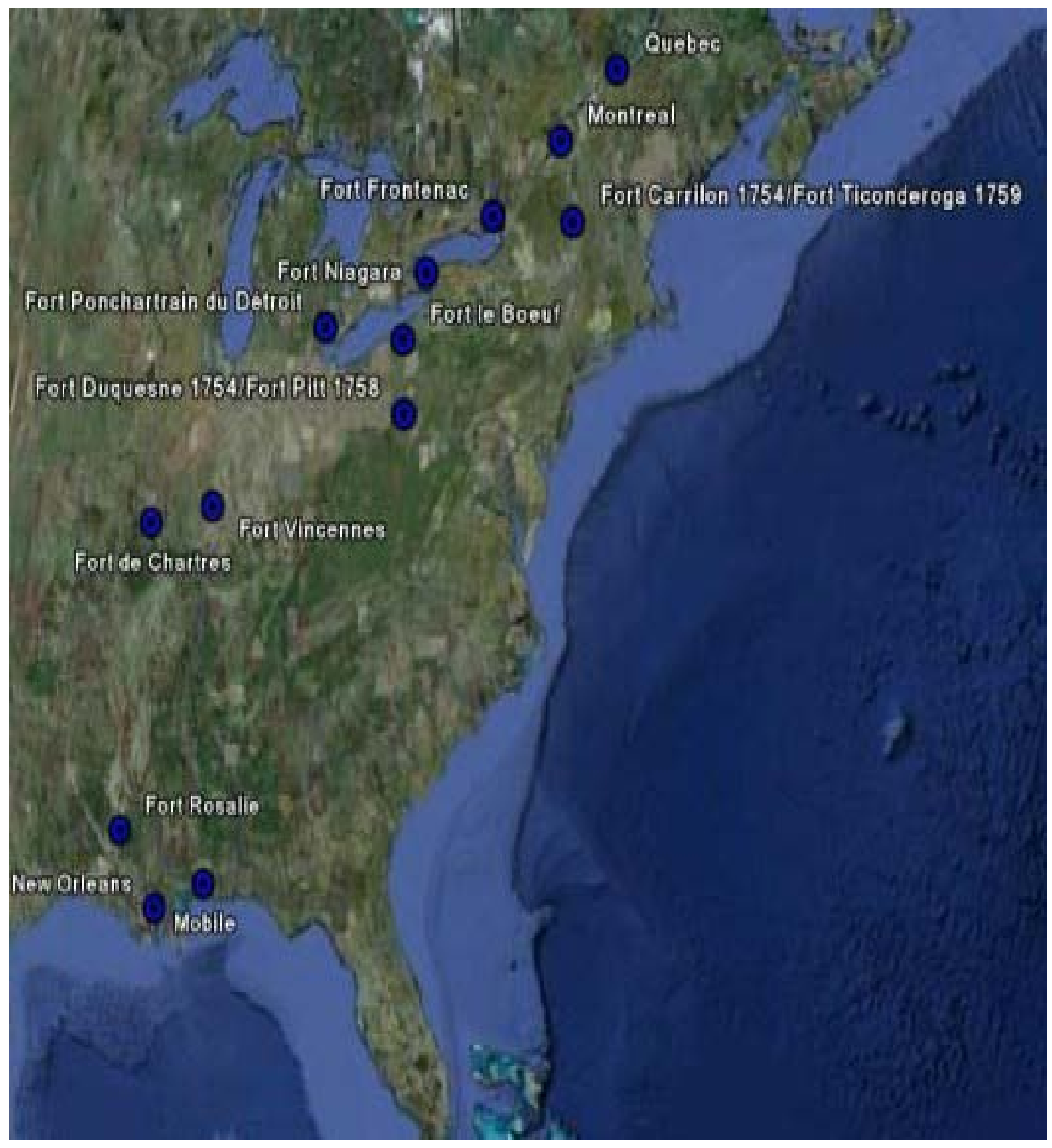


Royal Proclamation Line of 1763

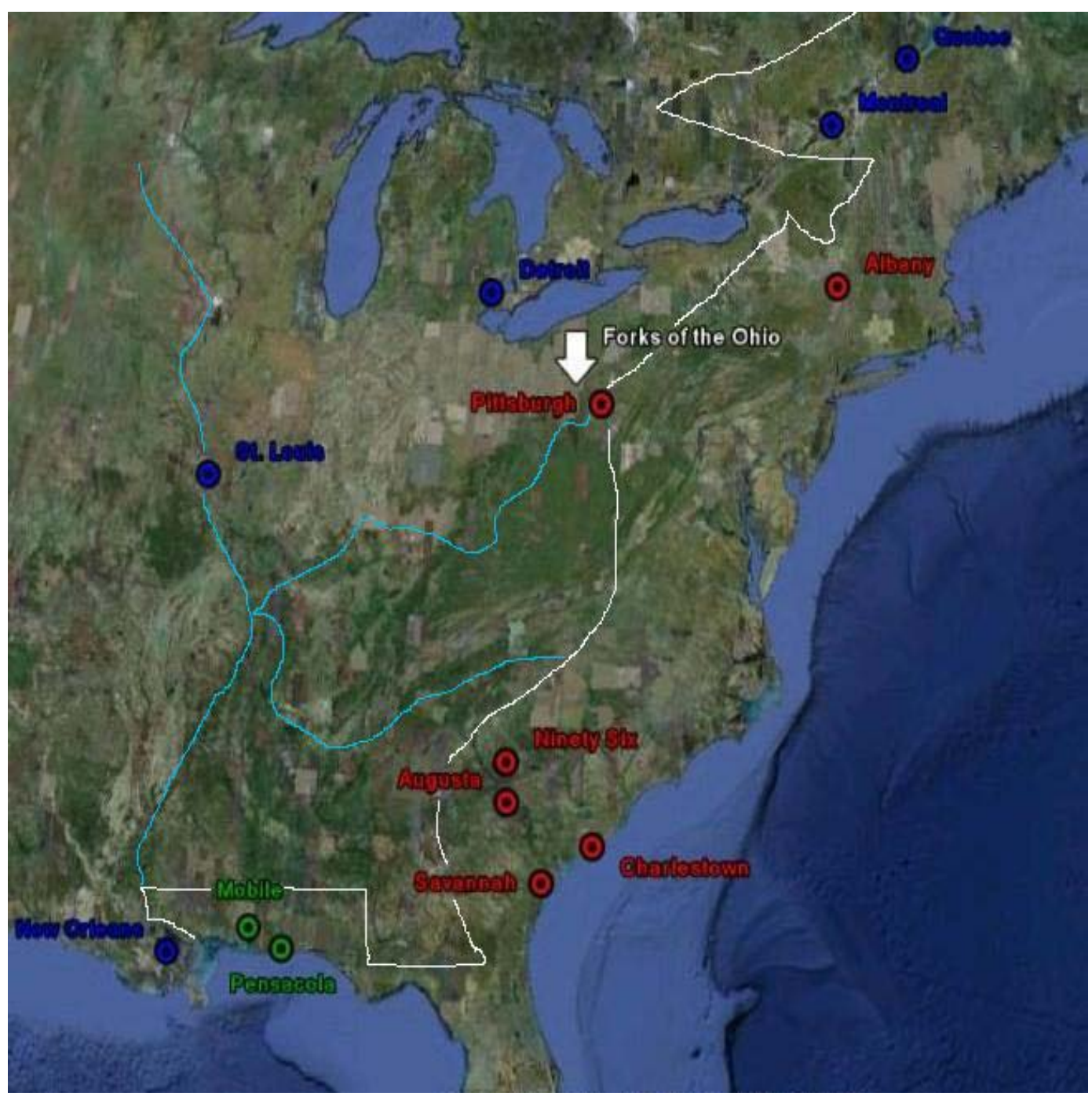


Bibliography

"A Missionary's Tour to Shamokin and the West Branch of the Susquhanna 1753." Pennsylvania Magazine of History and Biography. Vol 39 No 4 pp 440-444, 1915.

A.G. Doughty and N.E. Dionne. Quebec Under Two Flags. Quebec, Canada: The Quebec News Compnay, 1903.

Abernathy, Thomas Perkins. Western Lands and the American Revolution. New York and London: D. Appleton--Century Company Incorporated, 1937.

Baar, Daniel P. "Contested Land: Competition and Conflict Along the Upper Ohio Frontier, 1744-1784." Dissertation at Kent State University: Ann Arbor, Michigan USA:UMI, 2001.

Beer, George Louis. British Colonial Policy 1754-1765 . New York: Peter Smith (Reprinted by Special Arrangement with the MacMillion Company 1907), 1933.

Benn, Carl Eric. "The Iroquois in the War of 1812." Dissertation at York University. North York, Ontario: UMI, 1995.

Bluhm, Jr., Colonel Raymond. U.S. Army a Complete History. Arlington, Virginia: Hugh Lauter Levin Associates, Inc., 2004.

Bond, Beverly Jr. "The Quit-Rent System in the American Colonies." The American Historical Review Vol 17 No 3 pp 496-516, 1912.

Boucher, Christophe Jules Maurice. "The Legacy of Iouskeha and Tawiscaron: The Western Wendat People to 1701." Disseration at the University of Kansas. Ann Arbor, Michigan: UMI, 2001.

Brandao, Jose Antonio. "'Your fyre shall burn no more': Iroquois Policy Towards New France and Her Native Allies to 1701." Dissertation at York Univeristy: North York, Ontario. Ann Arbor, Michigan: UMI, 1994.

Braund, Kathryn E. Holland. "Mutual Convenience--Mutual Defense: the Creeks, Augusta, and the Deerskin Trade 1733-1783." Dissertation at Florida State University: Ann Arbor, Michigan, USA: UMI, 1986.

Brown, John P. Old Frontiers; The Story of the Cherokee Indians from Earliest Times to the Date of Their Removal to the West, 1838. Kingsport, Tennessee: Southern Publishers, Inc, 1938.

Camenzind, Krista. "From the Holy Expirement to the Paxton Boys: Violence, Manhood, and Race in Pennsylvania during the Seven Years War." Dissertation at the University of California, San Diego. Ann Arbor, Michigan: UMI, 2002. 
Carter, Clarence E. "British Policy Toward American Indians in the South 1763-1768." The English Historical Review, 1918: Vol 33 No 129 pp. 37-56.

Carter, Clarence E. "Document Relating to the Mississippi Land Company, 1763-1769." The American Historical Review, 1911. Vol 16 No 2 pp 311-319: Vol 16 No 2 pp 311-319.

Chalou, George Clifford. "The Red Pawns Go To War: British-Amerindian Relations 18101815." Dissertation at Indiana University: Ann Arbor, Michigan: UMI, 1971.

Charlevoix, Pierre Francois Xavier de. History and General Description of New France, Volume Four. Shea, John Gilmary, ed. New York, New York: Francis P. Harper, 1900.

Coker, Williams S. and Thomas D. Watson. Indian Traders of the Southeastern Spanish Borderlands: Panton, Leslie, and Company and John Forbes and Company 1783-1847. Pensacola, Florida: University of West Florida Press, 1986.

Collard, Edgar Andrew. Montreal. The Days That Are No More. Toronto, Canada: Doubleday Canada Limited, 1976.

Cook-Lynn, Elizabeth. Anti-Indianism in Modern America A Voice from Tatekeya's Earth. Chicago, Illinois: University of Illinois Press, 2001 .

Corkran, David H. The Creek Frontier . Norman, Oklahoma: Univeristy of Oklahoma Press, 1967.

Cox, Brent. Heart of the Eagle Dragging Canoe and the Emergence of the Chickamauga Confederacy. Milan, Tennessee: Chenanee Publishers, 1999.

Crane, Verner W. "Project for Colonization in the South 1684-1732." The Mississippi Valley Historical Review, 1925: Vol 12 No 1 pp. 23-35.

Crane, Verner W. "The Tennessee River as the Road to Carolina: The Beginnings of Explorartion and Trade." The Mississippi Valley Historical Review, 1916. Vol 3 No 1 pp 3-18.

Crumley, Carole L. "Remember How to Organize: Heterarchy Across Disciplines." In Nonlinear Models for Archaeology and Anthropology, by Editors. Christopher Beekman and William Baden. Burlington, Vermont: Ashgate Publishing Limited, 2005.

De Puy, Henry F. A Bibliography of the English Colonial Treaties with the American Indians: Including a Synopsis of Each Treaty . New York: Printed for the Lenox Club, 1917.

Deloria, Vine. "Civilization and Isolation." University of Northern Iowa. The North American Review, 1978: Vol 263 No 2 pp 11-14.

-. Custer Died for Your Sins an Indian Manifesto. Norman, Oklahoma: University of Oklahoma Press, 1988. 
—. For This Land Writing on Religion in America. New York: Routledge, 1999.

—. The Metaphysics of Modern Existance. San Francisco: Harper \& Row, 1979.

Dillon, John B. Oddities of Colonial Legislation in America, as Applied to the Public Lands, Primitive Education, Religion, Morals, Indians, Etc., Etc., with Authentic Records...with a Summary of the Territorial Expansion, Civil Progress and the Development of the Nation. Indianapolis, Indiania: Robert Douglas, Publisher-Electrotyped at the Indianapolis Electrotype Foundry, Ketcham and Wanamaker, Proprietors, 1879.

Dowd, Gregory Evans. "Paths of Resistance: American Indian Relgion and the Quest for Unity, 1745-1815, Volumes 1 \& 2." Dissertation at Princeton University. Ann Arbor, Michigan: UMI, 1986.

Drew, Bettina. "Master Andrew Jackson: Indian Removal and the Culture of Slavery." Dissertation at Yale University. Ann Arbor, Michigan: UMI, 2001.

Edmunds, David R. "Tecumseh, The Shawnee Prophet and American History: A Reassesment." The Western Historical Quarterly, 1983: Vol. 14 No. 3 pp. 261-276.

Edward, Douglas. "Colonial Indian Wars." In Handbook of North American Indians Volume 4. William C. Sturtevant \& Wilcomb E. Washburn, Editors: Smithsonian Institution: Washington, D.C., 1988.

Egnal, Marc. "The Origins of the Revolution in Virginia: A Reinterpretation." The William and Mary Quarterly, 1980: 3rd Ser. Vol 37 No 3 pp. 401-428.

Eliades, David K. "The Indian Policy of South Carolina 1670-1763." Dissertation at the University of South Carolina. Ann Arbor, Michigan: UMI, 1981.

Emmanuelli, Loliannette. "Spanish Diplomatic Policy and Contribution to the United States Independence 1775-1783." Dissertation at the University of Massachusetts. Ann Arbor, Michigan: UMI, 1990.

Fanon, Frantz. Black Skins White Masks Translated by Charles Lam Markmann. New York: Grove Press, Inc., 1967.

—. The Wretched of the Earth. New York: Grove Press, 1961.

Fierst, John Timothy. "The Struggle to Defend Indian Authority in the Ohio Valley-Great Lakes Region 1763-1794." Dissertation at the University of Manitoba (Canada). Ann Arbor, Michigan: UMI, 2000.

Finger, John R. "Tennessee Indian History: Creativity and Power." Tennessee Historical Quarterly, 1995: Vol 54 No 4 pp. 286-305. 
Fixico, Donald. "Federal and State Policies and American Indians." In A Companion to American Indian History. Edited by Philip J. Deloria and Neal Salisbury. Malden, Massachusetts: Blackwell Publishers, 2002.

Forbes, Jack D. Africans and Native Americans The Language of Race and the Evolution of RedBlack Peoples. Urbana \& Chicago: University of Illinois Press, 1993.

Foster, Lynn. "Courts and Lawyers on the Arkansas Frontier: The First Years of American Justice." The Arkansas Historical Quarterly, 2003: Vol 62, no. 3.

Franklin, Neil. W. "Oconostota, Cherokee Chieftain, Receives a Military Commission From Kerlerec, Louisiania Governor, 1761: French Text and English Translation." East Tennessee Historical Society's Publications, 1977: No 49 pp. 3-7.

Freeman, Shane. "The Land Systems of Colonial America, European and Native American Land Tenure Issues in the Colonial Eras of the Americas." Dissertation at West Virginia: Morgan Town, West Virginia. Ann Arbor, Michigan: UMI, 2004.

Fukuyama, Francis. The End of History and the Last Man With a New Afterword. New York: Free Press, 1992 \& 2006.

Gilbert Parker and Claude G.Bryan. Old Quebec. New York: The Quebec News Company, 1904.

Gitlin, Jay Larry. "Negotiating the Course of Empire: The French Bourgeois Frontier and the Emergence of Mid-America 1763-1863." Dissertation at Yale University . Ann Arbor, Michigan: UMI, 2002.

Goltz, Jr., Herbert. Tecumseh, The Prophet, and the Rise of the Northwest Indian Confederation. Dissertation at the University of Western Ontario: London, Canada, 1973.

Graves, William Hilton. "The Evolution of American Indian Policy." Dissertation at Florida State University. Ann Arbor, Michigan: UMI, 1982.

Greene, Jack P. The Reinterpretation of the American Revolution 1763-1789. New York, New York: Harper and Row, Publishers, 1968.

Grimes, Richard S. "The Emergence and the Decline of the Delaware Indian Nation in Western Pennsylvania and the Ohio Country 1730-1795." Dissertation at West Virginia Univeristy. Ann Arbor, Michigan: UMI, 2005.

Gross, Lawrence. "The Comic Vision of Anishinaabe Culture and Religion." American Indian Quarterly, 2002: Vol 26 No 3 pp 436-459.

Haan, Richard L. "Covenant and Consensus Iroquois and English 1676-1760." In Beyond the Covenant Chain, The Iroquois and Their Neighbhors in Indian North America 1600-1800. 
Daniel Richter and James Merrell, Editors. University Park, Pennsylvania: The Pennsylvania State University Press, 2003.

Haggard, Dixie Ray. "'Their Own Way of Warring": The Making and Persistence of Cherokee and Muscogulge Identity 1500-1800." Dissertation at the Univeristy of Kansas-Lawrence Campus. Ann Arbor, Michigan: UMI, 2006.

Hahn, Steven C. "The Invention of the Creek Nation: A Political History of the Creek Indians in the South's Imperial Era 1540-1763." Dissertation at Emory University. Ann Arbor, Michigan: UMI, 2000.

Hamilton, Milton W. The Papers of Sir William Johnson Volume XIII. Albany, New York: The University of the State of New York, 1962.

Hamilton, Peter J. Colnial Mobile. USA: University of Alabama Press, 1976.

Harvey, Henry. History of the Shawnee Indians, From the Year 1681 to 1854, Inclusive.

Cincinnati, Ohio: Ephraim Morgan and Sons, 1855.

Hatheway, G.G. "The Neutral Indian Barrier State a Project in British North American Policy 1754-1815." Dissertation at the University of Minnesota. Ann Arbor, Michigan: UMI, 1957.

Havard, Gilles. The Great Peace of Montreal 1701. Montreal: McGill-Queen's University Press, 2001.

Henderson, Archibald. "The Creative Forces in Westward Expansion: Henderson and Boone." The American Historical Review, 1914: Vol 20 No 1 pp 86-107: Vol 20 No 1 pp 86-107.

Holm, Tom. "American Indian Warfare: The Cycles of Conflict and the Militarization of Native North America." In A Companion to American Indian History. Edited by Philip J. Deloria and Neal Salisbury. Malden, Massachusetts. USA: Blackwell Publishers, 2002.

Hoopes, John W. "The Emergence of Social Complexity in the Chibchan World of Southern Central America and Northern Columbia, AD 300-600." Journal of Archaeological Research, 2005: Vol 13 No 1 pp 1-47.

Humphreys, R.A. "Lord Shelburne and the Royal Proclamation of 1763." The English Historical Review, 1934: Vol 49 No 194 pp 241-264.

Innis, Harold A. The Fur Trade in Canada. New Haven, Connecticut: Yale University Press, 1930.

J.W. Hagy and S.J. Folmsbee. "The Lost Archives fo the Cherokee Nation Part 1 1763-1772." The East Tennessee Historical Society's Publications, 1972: No 44 pp 114-125. 
Jacobs, Wilbur R., Editor. Indians of the Southern Colonial Frontier. The Edmond Atkin Report and Plan of 1755. Columbia, South Carolina: University of South Carolina Press, 1954.

Jennings, Francis. "Pennsylvania Indians and the Iroquois ." In Beyond the Covenant Chain. The Iroquois and Their Neighbors in Indian North America 1600-1800. Richter, Daniel K. and James H. Merrell, Editors. University Park, Pennsylvania: The Pennsylvania State University Press, 2003.

-. The Invasion of America Indians, Colonialism, and the Cant of Conquest. Williamsburg, Virginia: The University of North Carolina Press, 1975.

Kelly, James C. "Fort Loudoun: British Stronghold in the Tennessee Country." The East Tennessee Historical Society's Publications, 1978: No 50 pp. 72-91.

Koenig, Alexa and Jonathon Stein. "Federalism and the State Recognition of Native American Tribes: A Survey of State-Recognized Tribes and State Recognition Processes Across the United States." Santa Clara Law Review, 2007: Vol 48 pp 82-153.

Kupperman, Karen Ordahl, editor. Major Problems in American History Documents and Essays. Lexington, Massachusetts: D.C. Heath and Company, 1993.

La Duke, Winona. All Our Relations Native Struggles for Land and Life. Cambridge, Massachusetts: South End Press, 1999.

Labaree, Leonard Woods. Royal Instructions to British Colonial Governors 1670-1776 Volume II. New York and London: D. Appleton--Century Company Incorporated, 1935.

Macfarlane, Peter. "Two French Threats to North America 1760-1783 as seen by British Colonial Officials." Dissertation at Concordia University, Montreal, Quebec, 1999.

Mahon, John K. "Anglo-American Methods of Indian Warfare 1676-1794." The Mississippi Valley Historical Review, 1958: Vol 45 No 2 pp. 254-275.

Marshall, Peter. "Lord Hillsborough, Samuel Wharton and the Ohio Grant 1769-1775." The English Historical Review, 1965: Vol 80 No 3 pp 717-739.

Maulden, Kristopher. "The Arts of Conquest: The Rise of Federal Authority in Ohio 1783-1795." Dissertation at University of Missouri-Columbia. Ann Arbor, Michigan: UMI, 2005.

McClure, James Patrick. "The Ends of the American Earth: Pittsburgh and the Upper Ohio Valley to 1795 (Volumes 1 \& 2)." Disseratation at the University of Michigan . Ann Arbor, Michigan: UMI, 1983.

McConnell, Michael N. "People in Between; The Iroquois and the Ohio Indians 1720-1768." In Beyond the Covenant Chain. The Iroquois and Their Neighbors in Indian North America 1600- 
1800. Richter, Danile K. and James H. Merrell, Editors. University Park, Pennsylvania: The Pennsylvania State University Press, 2003.

McMillion, Ovid Andrew. "Cherokee Indian Removal: The Treaty of New Echota and General Winfield Scott." Dissertation at East Tennessee State University: Johnson City, Tennessee, 2003.

Mershon, S.L. English Crown Grants the Foundation of Colonial Land Titles Under English Common Law. New York, New York: The Law and History Club Publishers 39 Cortlandt Street, 1918.

Minges, Patrick. "Beneath the Underdog: Race, Religion, and the Trail of Tears." American Indian Quarterly, 2001. Vol 25 No 3 pp 453-479.

Moore, Charles. The Northwest Under Three Flags 1635-1796. New York and London: Harper and Brothers Publishers, 1900.

Nester, William R. The First Global War Britain, France, and the Fate of North America. Wesport, Connecticut: Praeger, 2000.

O'Callaghan, E. B. Documents Relative to the Colonial History of New York...Volume Five. Albany, New York: Weed, Parsons, and Company, Printers, 1855.

O'Callaghan, E.B. Documents Relative to the Colonial History of New York...Volume Four. Albany, New York: Weed, Parsons, and Company, Printers, 1854.

-. Documents Relative to the Colonial History of New York...Volume Nine. Albany, New York: Weed, Parsons, and Company, Printers, 1855.

-. Documents Relative to the Colonial History of New York...Volume Three. Albany, New York: Weed, Parsons, and Company, Printers, 1853.

Okerson, Barbara Buhr. "Weyapiersenweh Blue Jacket, War Chief of the Shawnees and the Contest for Possession of the Ohio River Valley." Dissertation at the University of Memphis. Ann Arbor, Michigan: UMI, 1996.

Otis Ashmore, J.F. Minnis, W.W. Mackall, \& T.J. Charlton. Letters of Benjamin Hawkins 17961806 Collections of the Georgia Historical Society. Savannah, Georgia: The Morning News, 1916.

Parker, Sara Gwenyth. "The Transformation of Cherokee Appalachia, 1755-1808." Dissertation at the University of California Berkely. Ann Arbor, Michigan: UMI, 1991.

Parmenter, Jon William. "At the Wood's Edge: Iroqouis Foreign Relations 1727-1768." Dissertation at the Univeristy of Michigan. Ann Arbor, Michigan: UMI, 1999. 
Pate, James Paul. "The Chickmauga: A Forgotten Segment of Indian Resistance on the Southern Frontier." Dissertation at Mississippi State University. Ann Arbor, Michigan: UMI, 1969.

Patricia Galloway and Jason Baird Jackson. Natchez and Neighboring Groups. Handbook of North American Indians, Vol 13. R.D. Fogelson, Editor. Washington, D.C.: Smithsonian Institute, 2004.

Pease, Theodore Calvin, Editor. Anglo-French Boundary Disputes in the West 1749-1763. French Series, Vol II. Collections of the Illinois Historical Library Vol XXVII. Springfiield, Illinois: Trustee of the Illinois State Historical Library, 1936.

Peretz, Paul. The Politics of American Economic Policy Making, 2nd Edition. Armonk, New York: M.E. Sharpe, Inc., 1996.

Piecuch, James R. "Three Peoples, One King: Loyalists, Indians, Slaves, and the American Revolution in the Deep South 1775-1782." Dissertation at the College of William and Mary. Ann Arbor, Michigan: UMI, 2005.

Pulitano, Elvira. "Native Theory and Criticism-1. United States." In The John Hopkins Guide to Literary Theory and Criticism, 2nd Ed. Edited by Groden, Martin and Szeman. Baltimore, Maryland: The John Hopkins University Press, 2005.

Quaife, Milo M. The Preston and Virginia Papers of the Draper Collection of Manuscripts Volume I. Madison, Wisconsin: State Historical Society of Wisconsiin, 1915.

Rafert, Stewart J. "The Hidden Community: The Miami Indians of Indiana 1846-1940." Dissertation at the University of Delaware. Ann Arbor, Michigan: UMI, 1982.

Rea, Robert R. Major Robert Farmer of Mobile. Tuscaloosa and London: The University of Alabama Press, 1990.

Richter, Daniel Karl. "The Orderal of the Longhouse: Change and Persistance on the Iroquois Frontier 1609-1720." Dissertation at Columbia University. Ann Arbor, Michigan: UMI, 1984.

Ropes, Arthur R. "The Causes of the Seven Years' War." Transactions of the Royal Historical Society. Royal Historical Society, 1889: Vol 4 New Series pp 143-170.

Rothrock, Mary U. "Carolina Traders Among the Overhill Cherokees 1690-1760." East Tennessee Historical Society's Publications, 1979: No 51 pp. 14-29.

Rushforth, Brett. "Savage Bonds: Indian Slavery and Alliance in New France." Dissertation at the Univeristy of California, Davis. Ann Arbor, Michigan: UMI, 2003.

Sato, Shosuke (Special Commissioner fo the Colonial Department of Japan. History of the Land Question in the United States: John Hopkins University Studies in Historical and Political 
Science, Fourth Series VII-VIII-IX. Herbert B. Adams, Editor. Baltimore, Maryland: N. Murray, Publication Agent and Isaac Friedenwald, Printer., 1886.

Saunt, Cladio. "A New Order of Things: Creeks and Seminoles in the Deep South Interior 17331816." Dissertation at Duke University. Ann Arbor, Michigan: UMI, 1996.

Savelle, Max. The Diplomatic History of the Canadian Boundary 1749-1763. New Haven, Connecticut: Yale University Press, 1940.

Shea, John Gilmary. Editor. Early Voyages Up and Down the Mississippi by Cavalier, St. Cosme, Le Sueur, Gravier, and Guignas. Munsell's Historical Series No. VIII. Albany, New York.: Joel Munsell, 1861.

Sheidley, Nathaniel J. "Unruly Men: Indians, Settlers, and the Ethos of Frontier Patriarchy in the Upper Tennessee Wateshed 1763-1815". Dissertation at Princeton University: Ann Arbor, Michigan, USA: UMI, 1999.

Smith, Adam. The Wealth of Nations Introduction by Alan B. Krueger. New York: Bantam Dell, 2003.

Smith, Linda Tuhiwai. Decolonizing Methodlogies. Dunedin: University of Otago Press, 1999.

Stevens, Paul Lawrence. "His Majesty's "Savage" Allies: British Policy and the Northern Indians during the Revolutionary War." Dissertation at State University of New York at Buffalo, 1984.

Stevens, Wayne E. "The Organization of the British Fur Trade 1760-1800." The Mississppi Valley Historical Review, 1916. Vol 3 No 2 pp 172-202.

Stone, Jr. Richard G. "Captain Paul Demere at Fort Loudon 1757-1760." The East Tennessee Historical Society's Publications, 1969: No 41 pp. 17-32.

Stuart, John. "John Stuart to the...Virginia Papers, Papers of the Continental Congress."

Washington, D.C.: The National Archives. M247 R85, 1763.

Stumpf, Stuart. "James Glen, Cherokee Diplomacy, and the Construction of an Overhill Fort." The East Tennessee Historical Society's Publications, 1978: No 50 pp. 21-30.

Tanner, Helen Hornbeck. "Cherokees in the Ohio Country." Journal of Cherokee Studies, 1978. Vol 3 No 2 pp 94-102.

Vickers, Paul Thomas. Chiefs of Nations: Review Copy The Cherokee Nation 1730 to 1839, 109 Years of Political Dialogue and Treaties. www.arkansascherokees.com: IuniversePublishers, 2005-06. 
Wainwright, Nicholas B. "George Croghan and the Indian Uprising of 1747." Lancaster, Pennsylvania: Presentation at the annual meeting of the Pennsylvania Historical Association, 1953.

Waley-Cohen, Joanna. The Sextants of Beijing. New York: W.W. Norton \& Company, 1999.

Walker, Mabel Gregory. "Sir John Johnson." The Mississippi Valley Historical Review, 1916. Vol 3 No 3 pp 318-346.

Wallace, Anthony F. Jefferson and the Indians The Tragic Fate of the First Americans. Cambridge, Massachusetts: The Belknap Press of Harvard University Press, 1999.

Wallace, Anthony F. with the assistance of Sheila C. Steen. The Death and Rebirth of the Seneca. New York: Vintage Books, a Division of Random House, 1972.

Wallace, Paul A. Conrad Weiser Freind of Colonist and Mohawk 1696-1760. Lewisburg, Pennsylvania: Wennawoods Publishing, 1996.

Warren, Stephen. "Between Villages and Nations: The Emergence of Shawnee Nationalism 1800-1870." Dissertation at the University of Indiania. Ann Arbor, Michigan: UMI, 2000.

Waters, Jim Great Elk. View From the Medicine Lodge. Santa Ana, California: Seven Locks Press, 2002.

White, Richard. The Middle Ground Indians, Empires, and Republics in the Great Lakes Region 1650-1815. New York, New York: Cambridge Univeristy Press, 1991.

Willig, Timothy D. "Restoring The Thin Red Line: British Policy and the Indians of the Great Lakes 1783-1812." Dissertation at the University of Massachusetts Amherst. Ann Arbor, Michigan: UMI, 2003.

Yellow Bird, M. "Cowboys and Indians Toys of Genocide Icons of American Colonization." Wicazo Sa Review, 2004: University of Minnesota Press.

Yoho, James. "Interest Groups in America, 1498-1861." Dissertation at the University of Virginia. Ann Arbor, Michigan: UMI, 1999.

Young, Robert J.C. Postcolonialism: An Historical Introduction. Malden, Massachusetts: Blackwell Publishers, 2001. 